ГОАОВНИЙ РЕААКТОР:

Вініченко I. I. , А.е.н., професор, завідувач кафедри економіки, Аніпровський державний аграрно-економічний університет

\section{ЗАСТУПНИКИ ГОАОВНОГО РЕААКТОРА: Федоренко В. Г.}

А.е.н., професор, заслужений діяч науки і техніки України, академік УАН, IПК АСЗУ

Аачій O.I.,

А.е.н., професор, заслужений працівник освіти України

\section{ВІАПОВІАА ЬНИЙ СЕКРЕТАР:}

Кучеренко Г.Б.

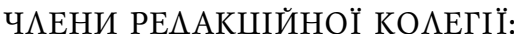

Безус Р. М., А.е.Н., професор, завідувач кафедри, Аніпровський державний аграрно-економічний університет

Бистряков I. K., д.е.н., професор, завідувач відділу, АУ «Інститут економіки природокористування та сталого розвитку НАН України»

Васильєва Н. К., А.е.н., професор, завідувач кафедри, Аніпровський державний аграрно-економічний університет Величко О. П., А.е.н., професор, завідувач кафедри, Аніпровський державний аграрно-економічний університет Гончаренко О. В., А.е.н., професор, професор кафедри, Аніпровський державний аграрно-економічний університет Гуазинський О.A., А.е.н., професор, професор кафедри, Національний університет біотехнологій і природокористування

Аемчук H. I., А.е.н., професор, професор кафедри, Аніпровський державний аграрно-економічний університет Катан $\Lambda$. I., А.е.н., професор, завідувач кафедри, Аніпровський державний аграрно-економічний університет

Кадієвський В. А., А.е.н., професор, завідувач кафедри, Аержавна академія статистики, обліку і аудиту

Крисанов А. Ф., А.е.н., професор, провідний науковий співробітник відаілу, АУ «Інститут економіки та прогнозування» НАН України

Кураташвілі А. А., А.е.Н, професор факультету Бізнестехнологій, Грузинський технічний університет (Тбілісі, Грузія),Академік іВіце-Президент Міжнародної Академії соціально-економічних наук, Міжнародної Академії політичного менеджменту, Міжнародної Академії Юридичних наук, дійсний член Нью-Иоркської Академіїї наук

Малік М. И., А.е.н., професор, завідувач відділу, ННЦ «Інститут аграрної економіки НААН України»

Павлова Г. Є., А.е.н., професор, професор кафедри, Аніпровський державний аграрно-економічний університет Плаксієнко В. Я., А.е.н., професор, завідувач кафедри, Полтавська державна аграрна академія

Савченко О. Ф., А.е.н., професор, професор кафедри, Павченко О. Ф., А.е.Н., професор, професор жаф УАьянченко О. В., член.кор. НААН України, А.е.н., професор, професор кафедри, Харківський національний аграрний університет ім. В.В. Аокучаєва

Чупіс А. В., А.е.н., професор, завідувач кафедри, Сумський нащіональний аграрний університет

Шиян А. В., А.е.н., професор, завідувач кафедри економіки підприємства та менеджменту, Харківський національний економічний університет імені Семена Кузнеця

Передрукування дозволяється лише за згодою редакці1. Відповідальність за добір і викладення Фактів несуть автори. Редакція не завжАи поділяє позицію авторів публікацій. За зміст та Аостовірність реклами несе відповіАальність рекламодавець

Свідоцтво КВ № 23728-13568ПР від 27.12.2018 року ISSN 2306-6792

Передплатний індекс: 21847 Засновники:

Аніпровсъкий державний

аграрно-економічний університет, TOB "АКС Центр"

Видавець:

TOB"АКС Центр"

Адреса редакції:

04112, м. Київ, вул.Аорогожицька, 18, к. 29

Телефон: (044) 223-26-28, (044) 537-14-33

Телефон / факс: (044) 458-10-73 www.agrosvit.info

E-mail: economy_2008@ukr.net

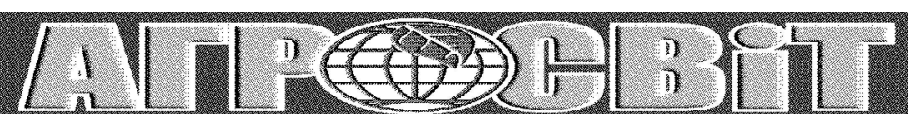

Журнал засновано у січні 2001 року. Виходить 2 рази на місяць.

\section{№ 9 травень 2019 р.}

\section{У HOMEPI:}

Вихор М. В., Коваль Н. В., Шемігон О. I.

Програмно-цільовий підхід у процесі забезпечення конкурентоспроможності національної економіки . 3

Аевандівсъкий О. T.

Зарубіжний досвід підвищення інвестиційної активності сільськогосподарських

підприємств .10

Меліхова T. O.

Методичні засади проведення внутрішнього контролю розрахунків з покупцями та замовниками для підвищення ефективності фінансово-господарської діяльності підприємства .17

Руда О. $\Lambda$.

Сучасні тенденції на ринку банківських послуг

в Україні та їх вплив на фінансову діяльність

банківської системи

Васильєв С. В., Кривонос А. О.

Методи підвищення ефективності

управління підприємств України в сучасних

умовах

Ковальов А. В.

Оцінка ключових тенденцій у трансформації

зайнятості населення Херсонської області

та змін у ї̈ структурі

Артеменко $\Lambda$. Б.

Європейський досвід державної підтримки органічного виробництва у контексті забезпечення продовольчої безпеки

України ..... 46

Коваль А. В., Болехівська В. В.

Бухгалтерський облік власного капіталу в управлінні підприємством

Журнал Включено до переліку наукових фахових видань

Украӥни, в лких можуть публікуватисл результати

дисертачійних робіт на здобуття наукових ступеніь доктора і кандидата наук з ЕКОНОМІКИ

(постанова президії ВАК України № 1-05/2 віة

27.05.2009 p., наказ ВАК Украӥни № 340 від 21.04.2011 p. «Про внесення змін до переліку наукових фахових видань

України», наказ Міністерства освіти і науки України № 1528 Bid 29.12.2014)

ІНАЕКСАЦІЯ ВИААННЯ В НАУКОМЕТРИЧНИХ БАЗАХ: Index Copernicus (IC); SIS; Google Scholar.

Рекомендовано до друку

Вченою радою Аніпровського державного аграрно-економічного університету 16.05 .2019 p.

Підписано до друку 16.05.19 р.

Формат 60х84 1/8, Ум. Арук. арк. 7.5. Наклад -1000 прим. Папір крейдований, друк офсетний. Замовлення № 1605/2 
№ 9 / 2019

\section{CONTENTS:}

Vykhor M., Koval N., Shemigon O.

PROGRAM-TARGET APPROACH IN THE NATIONAL ECONOMY COMPETITIVENESS

PROVIDING PROCESS

Levandivskyi O.

FOREIGN EXPERIENCE IN INCREASING THE INVESTMENT ACTIVITY

OF AGRICULTURAL ENTERPRISES

Melikhova T.

METHODICAL PRINCIPLES OF SETTLEMENTS INTERNAL CONTROL WITH BUYERS

AND CUSTOMERS FOR INCREASING THE EFFICIENCY OF FINANCIAL

AND ECONOMIC ACTIVITY OF THE ENTERPRISE

Ruda O.

CONTEMPORARY TRENDS IN THE BANKING SERVICES MARKET IN UKRAINE AND THEIR

IMPACT ON THE FINANCIAL ACTIVITY OF THE BANKING SYSTEM ....

Vasil'ev S., Krivonos A.

THE METHODS OF ENHANCE THE EFFECTIVENESS OF UKRAINE'S ENTERPRISES

MANAGEMENT IN MODERN CONDITIONS

Kovalyov D.

ASSESSMENT OF KEY TENDENCIES IN TRANSFORMATION OF EMPLOYMENT OF POPULATION

OF KHERSON REGION AND CHANGES IN ITS STRUCTURE .

Artemenko L.

EUVROPIEN EXPERIENCE OF GOVERNMENT SUPPORT OF THE ORGANIC PRODUCTION

IN THE CONTEXT OF ENSURING FOOD SECURITY OF UKRAINE.

Koval L., Bolekhivska V.

ACCOUNTING OF OWN CAPITAL IN MANAGEMENT ENTERPRISE

\section{ДО УВАГИ АВТОРІВ!}

ВИМОГИ АО СТРУКТУРИ ТА ОФОРМАЕННЯ МАТЕРІААУ

- У статті з лівого боку має стояти індекс УАК (регистр - «ВСЕ ПРОПИСНЫЕ»).

- Ініціали та прізвище автора. Через кому після ПІБ зазначається науковий ступінь, вчене звання, посада, науковий заклад (мовою статті та англійською мовою).

- Назва статті (регистр - «Как в предложениях») мовою статті та англійською мовою.

- Анотація мовою статті та англійською мовою.

- Ключові слова (5-8 слів) мовою статті та англійською мовою.

- Текст статті.

У статті, згідно постанови Президії Вищої атестаційної комісії України «Про підвищення вимог до фахових видань, внесених до переліків ВАК України» від 15 січня 2003 р. № 7-05/1, повинні міститись (із виділенням у тексті) такі елементи: постановка проблеми у загальному вигляді та її зв'язок із важливими науковими чи практичними завданнями; аналіз останніх досліджень і публікацій, в яких започатковано розв'язання даної проблеми і на які спирається автор, виділення не вирішених раніше частин загальної проблеми, котрим присвячується означена стаття; формулювання цілей статті (постановка завдання); виклад основного матеріалу дослідження 3 повним обгрунтуванням отриманих наукових результатів; висновки з даного дослідження і перспективи подальших розвідок у даному напрямі; список використаних джерел (оформлюється за новими вимогами, які опубліковані у Бюлетні ВАК України, № 3, 2008).

Згідно нових правил, які враховують вимоги міжнародних систем цитування, автори статей повинні давати список літератури в двох варіантах: один на мові оригіналу і окремим блоком той же список літератури (References) в романському алфавіті (harvard reference system), повторюючи в ньому всі джерела літератури, незалежно від того, чи є серед них іноземні

- Обсяг рукопису - 15-25 тис. знаків, включаючи рисунки, таблиці.

- Стаття повинна бути виконана у форматі A-4 текстового редактора Microsoft Word for Windows (шрифтTimes New Roman) у вигляді файла з розширенням.doc або.rtf для Microsoft Word (версія 97-2003). Файли статті обов'язково повинні бути збережені в форматі.doc aбо.rtf.

- Ілюстративний матеріал повинен бути поданий чітко і якісно у чорно-білому вигляді. Посилання на ілюстрації в тексті статті обов'язкові. Рисунки, виконані у MS Word, потрібно згрупувати; вони повинні бути єдиним графічним об'єктом. Аля рисунків, зроблених в програмі Excel, потрібно додатково до статті відправити файл Excel (2003). боку.

— Формули виконуються за допомогою вбудованого редактора формул MS Equation і нумеруються 3 правого

Редакція залишає за собою праВо на незначне редагуВання і скорочення, а також літературне Виправлення статті (зі збереженням головних висновків та стилю автора). Надані матеріали не повертаються. 


\title{
УАК 339.137.2:330.5
}

\section{М. В. Вихор,}

к. е. н., доцент, доцент кафеАри менеАжменту,

Білоцерківський національний аграрний університет

ORCID ID: 0000-0001-9799-4678

Н. В. Коваль,

к. е. н., Аоцент, доцент кафеАри менеАжменту,

Білоцерківський національний аграрний університет

ORCID ID: 0000-0003-1244-9297

O. I. Шемігон,

к. с-г. н., Аоцент, доцент кафеАри менеАжменту,

Білоцерківський національний аграрний університет

ORCID ID: 0000-0002-4920-6427

DOI: $10.32702 / 2306-6792.2019 .9 .3$

\section{ПРОГРАМНО-ЦІАЬОВИЙ ПІАХІА У ПРОЦЕСІ ЗАБЕЗПЕЧЕННЯ КОНКУРЕНТОСПРОМОЖНОСТІ НАЦІОНАЛЬНОÏ ЕКОНОМІКИ}

\author{
M. Vykhor, \\ Ph.D. in Economics, Associate Professor of the Department of management, Bila Tserkva National Agrarian University \\ N. Koval, \\ Ph.D. in Economics, Associate Professor of the Department of management, Bila Tserkva National Agrarian University \\ O. Shemigon, \\ Ph.D. in Agricultural Sciences, Associate Professor of the Department of management, Bila Tserkva National Agrarian University
}

\section{PROGRAM-TARGET APPROACH IN THE NATIONAL ECONOMY COMPETITIVENESS PROVIDING PROCESS}

АосліАжено деякі аспекти застосування програмно-цільового підходу у процесі забезпечення конкурентоспроможності національної економіки. Визначено, що державні цільові програми є ефективним інструментом реалізації Аержавних стратегій, спрямованих на підвищення конкурентоспроможності національної економіки. Зазначено, що програмно-цільовий підхіА $є$ одним із методів планування, який передбачає чітке визначення цілей, шляхів і термінів ї досягнення, обсягів необхідних ресурсів. Розкрито очевидні переваги програмно-цільового підходу, Ао яких відносяться наявність чітко визначеної мети, переліку робіт та термінів їх виконання, визначеність щодо обсягів матеріальних, фінансових, трудових та інших ресурсів, ієрархічність цілей програми, висока ефективність контролю. Вказано на окремі проблеми практичного застосування програмно-цільового підходу у системі державного управління та причини їх виникнення. Зазначено, що основними із них є відсутність системності, фрагментарність, завищена оцінка реальних можливостей національної економіки, формальність при реалізації державних цільових програм та ї постійне недофінансування.

The importance and necessity of the growing national economy competitiveness has been emphasized in the current state of circumstances. The main component of the issue solving mechanism is a development of relevant government policies and targeted programs and its implementation.

There were specified the key features of the program-target approach in the national economy competitiveness providing process. The program-target approach is one of the planning methods provided for a clear definition of goals, ways and terms of its achievement, the volume of necessary resources. Targeted programs are detailing and specifying the ways and implementation key methods, specified in government policies, aimed at growing of the national economy competitiveness. There were determined obvious advantages of the program-target approach embracing a clearly defined goal in the form of a specific final quantitatively result, an accurate list of works and terms of their execution, a definition of material, finance, labour and other resources volumes, hierarchy of the program goals, high control effectiveness. 
Qualitative characteristics of some active state strategies in Ukraine aimed at growing of the national economy competitiveness and collaboration with relevant state targeted programs has been analysed. State targeted programs did not become an effective realization instrument of this strategies. The root causes of all problems in the process of the program-target approach to practical implementation of strategies of the growing competitiveness has been studied. The main problems are the lack of consistency, fragmentation, overestimated of the national economy real possibilities, formality at implementation of state target programs and permanent underfunding. In the process of drafting process, the relevant state institutions have to take into consideration the place of Ukraine in the global competitiveness according to certain parameters and develop methods to enhance weaker positions based on the strongest.

Ключові слова: державні чільові програми, стратегї, конкурентоспроможність, начіональна економіка.

Key words: state target programs, strategies, competitiveness, national economy.

\section{ПОСТАНОВКА ПРОБЛЕМИ}

Питання радикального підвищення конкурентоспроможності національної економіки залишаються одними із ключових і постійно обговорюваних протягом всього періоду незалежності України, що знаходить своє відображення як у економічній літературі, так і у офіційних документах загальнодержавного рівня. Зокрема в Указі Президента України "Про Стратегію Сталого розвитку "Україна-2020" визначено, що одним із стратегічних індикаторів реалізації Стратегії є входження України до числа 40 країнлідерів за індексом глобальної конкурентоспроможності [1]. У вітчизняній практиці державного управління вирішення цієї і ряду інших, ключових для країни завдань, здійснюється через розробку відповідних стратегій та цільових програм їх реалізації. Але, як показує досвід, у цьому процесі з'являється ряд методичних та організаційно-практичних проблем, що суттєво ускладнює досягнення запланованих результатів.

\section{АНАЛІЗ ОСТАННІХ ДОСЛІДЖЕНЬ І ПУБЛІКАЦІЙ}

Проблемі обгрунтування шляхів підвищення конкурентоспроможності національної економіки та її окремих сфер приділяли увагу у своїх публікаціях такі вчені: Б. Гаврилишин, А. Гальчинський, В. Геєць, А. Гриценко, В. Горбулін, В. Аипов, О. Тимошенко, О. Яременко та інші. Застосування програмно-цільового підходу у системі державного та регіонального управління досліджувались у працях В. Герасимчука, О. Головні, Р. Жебчука, Н. Мущинської, Н. Статівки, І. Стеблянко, Ю. Шкворця та ряду інших фахівців. Одначе, не зважаючи на значну кількість досліджень і публікацій, деякі аспекти застосування програмно-цільового підходу у процесі забезпечення конкурентоспроможності національної економіки потребують подальших досліджень.

\section{META CTATTI}

Метою статті є дослідження теоретико-методичних та практичних аспектів застосуван- ня програмно-цільового підходу у процесі вирішення завдань із забезпечення конкурентоспроможності національної економіки

\section{ВИКЛАД ОСНОВНОГО МАТЕРІАЛУ}

Програмно-цільовий підхід до вирішення стратегічно важливих для організацій, регіонів чи держав завдань $є$ достатньо поширеним у практиці управління. Вперше його почали використовувати у США в 60-х роках минулого століття, потім у Західній Європі і Японії. Хоча деякі автори вказують на те, що історичний досвід застосування програмно-цільового підходу мав місце ще у 20-ті роки минулого століття при розробці плану ГОЕ $\Lambda$ РО у тодішній Росії та у період Великої кризи у США [2].

Як зазначає I. Стеблянко, програмно цільовий підхід $€$ одним із методів планування, в основі якого лежить орієнтація діяльності на досягнення поставлених цілей. При цьому процес планування починається із визначення та постановки цілей і лише потім здійснюється вибір шляхів їх досягнення. Програмно цільове планування побудоване за логічною схемою "цілі - шляхи - способи - засоби" [3, с. 38]. 3 ним погоджується В. Герасимчук, вказуючи на те, що особливість застосування програмноцільового управління полягає, насамперед, у концентрації необхідного обсягу і видів ресурсів, з одного боку, при вирішенні важливих проблем, що накопичувалися роками чи десятиліттями, а з другого - для постановки і вирішення завдань, що носять пріоритетний, проривний характер [2]. Ао цього слід додати ще одну важливу особливість цільових програм фіксованість терміну їх реалізації.

Узагальнюючи сказане, основними перевагами програмно-цільового управління можна віднести такі:

— наявність чітко визначеної цілі у вигляді конкретного кінцевого кількісно визначеного результату;

- наявність чіткого переліку робіт та термінів їх виконання, необхідних для досягнення поставленої цілі; 


\section{Таблиця 1. Індекс глобальної конкурентоспроможності України за складовими}

\begin{tabular}{|c|c|c|c|c|}
\hline \multirow{2}{*}{$\begin{array}{c}\text { Індекс глобальної конкурентоспроможності } \\
\text { (позиції України за складовими) }\end{array}$} & $\begin{array}{c}2014-2015 \text { pp. } \\
\text { (144 країни) }\end{array}$ & $\begin{array}{c}2015-2016 \text { pp. } \\
(140 \text { країн })\end{array}$ & $\begin{array}{c}\text { 2016-2017 p p. } \\
\text { (138 країн) }\end{array}$ & $\begin{array}{c}\text { 2017-2018 pp. } \\
\text { (137 країн) }\end{array}$ \\
\hline & 76 & 79 & 85 & 81 \\
\hline Основні вимоги & 87 & 101 & 102 & 96 \\
\hline Інституції & 130 & 130 & 129 & 118 \\
\hline Державні установи: & 131 & 130 & 132 & 117 \\
\hline право власності & 135 & 131 & 130 & 128 \\
\hline етика і корупція & 120 & 107 & 109 & 106 \\
\hline зловживання впливом & 131 & 125 & 127 & 129 \\
\hline безпека & 124 & 132 & 123 & 106 \\
\hline Приватні установи: & 120 & 110 & 123 & 109 \\
\hline корпоративна етика & 98 & 76 & 106 & 102 \\
\hline підзвітність & 127 & 130 & 130 & 111 \\
\hline Інфраструктура & 68 & 69 & 75 & 78 \\
\hline Транспортна інфраструктура & 88 & 91 & 91 & 87 \\
\hline якість усієї інфраструктури & 75 & 82 & 88 & 88 \\
\hline якість доріг & 139 & 132 & 134 & 130 \\
\hline якість залізничної інфраструктури & 25 & 28 & 34 & 37 \\
\hline якість портової інфраструктури & 107 & 108 & 96 & 93 \\
\hline якість інфраструктури повітряного транспорту & 99 & 97 & 103 & 92 \\
\hline Електрика і телефонна інфраструктура & 51 & 54 & 62 & 68 \\
\hline якість постачання електроенергії & 69 & 75 & 86 & 85 \\
\hline якість абонентів мобільного зв'язку/ 100 чол. & 33 & 32 & 26 & 37 \\
\hline якість абонентів фіксованого зв'язку/ 100 чол. & 45 & 44 & 47 & 51 \\
\hline Макроекономічне середовище & 105 & 134 & 128 & 121 \\
\hline Баланс держбюджету, \% від ВВП & 99 & 104 & 25 & 53 \\
\hline Валові національні заощадження, \% від ВВП & 134 & 124 & 99 & 88 \\
\hline Інфляція, зміна за рік у \% & 75 & 134 & 136 & 129 \\
\hline Державний борг, \% від ВВП & 66 & 110 & 113 & 112 \\
\hline Охорона здоров'я та початкова освіта & 43 & 45 & 54 & 53 \\
\hline Охорона здоров'я & 82 & 82 & 83 & 84 \\
\hline $\begin{array}{l}\text { рівень захворюваності на туберкульоз/ на } 100000 \\
\text { жителів }\end{array}$ & 90 & 88 & 91 & 92 \\
\hline поширеність ВІЛ, \% дорослого населення & 106 & 104 & 111 & 104 \\
\hline дитяча смертність/ 1000 новонароджених & 54 & 53 & 51 & 50 \\
\hline очікувана тривалість життя & 88 & 87 & 92 & 92 \\
\hline Початкова освіта & 32 & 34 & 50 & 43 \\
\hline якість початкової освіти & 40 & 45 & 51 & 42 \\
\hline зарахування до початкової освіти & 31 & 33 & 57 & 62 \\
\hline
\end{tabular}

Ажерело: [6; 7].

— визначеність щодо обсягів матеріальних, фінансових, трудових та інших ресурсів, необхідних для виконання програми;

- ієрархічність цілей програми, що дає можливість здійснювати їх декомпозицію і ув'язувати локальні одиничні цілі програми із загальним результатом;

- висока ефективність контролю, оскільки у любий момент часу можна точно визначити відповідність фактично виконаного обсягу робіт, термінів їх виконання, витрат ресурсів запланованим параметрам та оперативно вносити необхідні корективи.

Саме завдяки згаданим перевагам програмно-цільове управління набуло поширення як на рівні окремих підприємств, так і на державному та регіональному рівнях. Це, зокрема, знайшло підтвердження у Законі України "Про держані цільові програми" де зазначено, що "державна цільова програма це комплекс взаємопов'язаних завдань і заходів, які спрямовані на розв'язання найважливіших проблем розвитку держави, окремих галузей економіки або адміністративно-територіальних одиниць, здійснюються з використанням коштів Аержавного бюджету України та узгоджені за строками виконання, складом виконавців, ресурсним забезпеченням" [4].

У Законі визначено, що державні цільові програми поділяються на:

- загальнодержавні програми економічного, науково-технічного, соціального, національно-культурного розвитку, охорони довкілля (далі - загальнодержавні програми) - це програми, які охоплюють всю територію держави або значну кількість її регіонів, мають довгостроковий період виконання і здійснюються центральними та місцевими органами виконавчої влади;

— інші програми, метою яких є розв'язання окремих проблем розвитку економіки і суспільства, а також проблем розвитку окремих галузей економіки та адміністративно-територіальних одиниць, що потребують державної підтримки [4]. 
Таблиця 2. Основні стратегічні документи щодо підвищення конкурентоспроможності держави, галузей та регіонів

\begin{tabular}{|c|c|c|c|}
\hline & Назва документу & Характеристика & Особливості, недоліки, упущення \\
\hline 1 & $\begin{array}{l}\text { Стратегія економічного та соціального } \\
\text { розвитку України на 2004-2015 рр. } \\
\text { «Шляхом європейської інтеграції» } \\
\text { (2004 р.) }\end{array}$ & $\begin{array}{l}\text { Стратегічними пріоритетами визначено: } \\
\text { а) створення передумов для набуття Україною } \\
\text { членства у СС; б) забезпечення сталого } \\
\text { економічного росту; в) утвердження інноваційної } \\
\text { моделі розвитку; г) соціальна переоріснтація } \\
\text { економічної політики; д) обгрунтовано кадрову, } \\
\text { фінансову, інституційно-організаційну складові } \\
\text { НТП }\end{array}$ & $\begin{array}{l}\text { Має описовий характер, відсутній } \\
\text { чіткий стратегічний план дій для } \\
\text { країни на перспективу. Прогнозні } \\
\text { оцінки основних макроекономічних } \\
\text { показників не були отримані. }\end{array}$ \\
\hline 2 & $\begin{array}{l}\text { Національна стратегія розвитку } \\
\text { «Україна } 2015 », \text { розроблена IЕП НАН } \\
\text { України (2008 р.) }\end{array}$ & $\begin{array}{l}\text { Проголошено перехід до випереджального розвитку. } \\
\text { Названо стратегічні шляхи розвитку: підтримка } \\
\text { науково-технологічного потенціалу України за } \\
\text { напрямками, які здатні забезпечити конкурентні } \\
\text { переваги та національну безпеку, досягнення обсягів } \\
\text { виробництва 90-pр. на інноваційній основі }\end{array}$ & $\begin{array}{l}\text { Не зважаючи на масштабність } \\
\text { підходів до інноваційного розвитку, } \\
\text { загальне спрямування механізмів, } \\
\text { інструментів реалізації стратегії } \\
\text { головна мета - соціалізація економіки } \\
\text { на інноваційній основі - не стала } \\
\text { ключовою у програмі дій }\end{array}$ \\
\hline 3 & $\begin{array}{l}\text { Стратегія національної модернізації } \\
\text { «Україна 2020», розроблена } \\
\text { Мінекономіки України (2009-2010рр.) }\end{array}$ & $\begin{array}{l}\text { Визначені ключові напрямки втілення економічної } \\
\text { політики держави, що повинні бути реалізовані у два } \\
\text { етапи: 1) середньостроковий - до } 2012 \text { року, } \\
\text { спрямований на розширене використання наукового } \\
\text { та інноваційного ресурсів промисловості; } \\
\text { 2) довгостроковий - до } 2020 \text { року, спрямований на } \\
\text { формування та нарощення конкурентоспроможності } \\
\text { держави }\end{array}$ & $\begin{array}{l}\text { Відсутній організаційно-економічний } \\
\text { механізм та засоби досягнення } \\
\text { запропонованих напрямів } \\
\text { інноваційного розвитку. Не } \\
\text { розглянутими залишилися окремі } \\
\text { термінові стратегічні завдання }\end{array}$ \\
\hline 4 & $\begin{array}{l}\text { Стратегія інноваційного розвитку } \\
\text { України на 2010-2020 роки в умовах } \\
\text { глобалізаційних викликів, розроблена } \\
\text { на виконання Постанови ВРУ від } \\
\text { 17.02. } 2009 \text { р., № 965-УІ }\end{array}$ & $\begin{array}{l}\text { Передбачено два етапи здійснення: 1) відтворення } \\
\text { технологічної бази галузей, продукція яких } \\
\text { користується стабільним попитом на ринках; } \\
\text { 2) створення виробництв, що реалізують новітні } \\
\text { технологічні уклади та вихід на ринок із } \\
\text { наукомісткою продукцією світового рівня. } \\
\text { Забезпечення формування інноваційної культури } \\
\text { населення }\end{array}$ & $\begin{array}{l}\text { Переважає фрагментарність та не } \\
\text { комплексність вирішення питань } \\
\text { навіть в одній галузі економіки }\end{array}$ \\
\hline 5 & $\begin{array}{l}\text { Державна стратегія регіонального } \\
\text { розвитку на період до } 2020 \text { року, } \\
\text { затверджена постановою КМУ від } \\
6.08 .2014 \text { р. № } 385\end{array}$ & $\begin{array}{l}\text { Спрямована на визначення завдань та інструментів } \\
\text { для розв’язання соціальних проблем, підвищення } \\
\text { рівня економічного потенціалу територій, } \\
\text { продуктивності їх економіки, прибутковості бізнесу } \\
\text { та доходів населення }\end{array}$ & $\begin{array}{l}\text { Спрямована на боротьбу із } \\
\text { внутрішніми проблемами і загрозами. } \\
\text { Цілі зміни інноваційного сектору } \\
\text { наведені у показниках обсягу робіт, не } \\
\text { пов'язаних із процесами розвитку } \\
\text { інноваційної сфери }\end{array}$ \\
\hline 6 & $\begin{array}{l}\text { Концепція Загальнодержавної цільової } \\
\text { економічної програми розвитку } \\
\text { промисловості на період до } 2020 \text { року, } \\
\text { затверджена розпорядженням КМУ від } \\
\text { 17. 07. } 2013 \text { р., № 603-р }\end{array}$ & $\begin{array}{l}\text { Зорієнтована на відновлення стратегічної ролі } \\
\text { вітчизняної промисловості у стимулюванні } \\
\text { економічного зростання та підвищення } \\
\text { конкурентоспроможності економіки України, } \\
\text { підвищення рівня інноваційної та інвестиційної } \\
\text { діяльності }\end{array}$ & $\begin{array}{l}\text { Відсутній чіткий механізм здійснення } \\
\text { інноваційної діяльності, інформації } \\
\text { про проривні інноваційні ідеї } \\
\text { розвитку промисловості }\end{array}$ \\
\hline 7 & $\begin{array}{l}\text { Стратегія сталого розвитку «Україна } \\
2020 », \text { схвалена Указом Президента } \\
\text { України від 12.01.2015 р., № } 5\end{array}$ & $\begin{array}{l}\text { Спрямована на стабілізацію техногенного } \\
\text { навантаження на природне середовище, вирішення } \\
\text { низки екологічних питань, реалізацію програми } \\
\text { енергоефективності, реформування захисту } \\
\text { інтелектуальної власності }\end{array}$ & $\begin{array}{l}\text { Потребує методології та доповнення } \\
\text { компонентами забезпечення сталого, } \\
\text { зокрема інноваційного розвитку } \\
\text { країни }\end{array}$ \\
\hline
\end{tabular}

Ажерело: розроблено авторами на основі [10, с. 475-477].

Очевидно, що загальнодержавні цільові програми мають стати ефективним інструментом реалізації стратегій, спрямованих на підвищення конкурентоспроможності національної економіки. Це тим більше важливо із врахуванням того факту, що Україна, протягом останніх 15 років, у рейтингу країн за індексом глобальної конкурентоспроможності не піднімалась вище 72 місця, що було у 2008 році [5, с. 135]. У 2017-2018 роках Україна за цим показником посіла 81 місце серед 137 країн світу (табл. 1).

При визначенні концептуальних засад вітчизняного підходу до підвищення конкурентоспроможності національної економіки слід враховувати як нинішнє так і майбутнє місце України у глобальному міжнародному поділі праці. Як зауважує у зв'язку із цим В.В.
$\Lambda$ ипов, в Україні можуть бути реалізовані два сценарії розвитку. Перший передбачає збереження та відновлення єдиного цілісного багатогалузевого диверсифікованого народногосподарського комплексу. Аругий грунтується на інтенсивній міжнародній диверсифікації, при якій ресурси ідуть на розвиток обмеженої кількості орієнтованих на експорт галузей $[8$, с. 23]. Очевидно, що для однієї із найбільших за територією і населенням країн Європи другий сценарій $€$ набагато менш прийнятним і перспективним.

У практичній площині організаційною основою робіт, зв'язаних із підвищенням конкурентоспроможності національної економіки є документи, які визначають стратегічні пріоритети розвитку держави (табл. 2). Серед тих, які 
продовжують термін своєї дії до 2020 року можна назвати "Стратегію національної модернізації "Україна 2020", "Стратегію інноваційного розвитку України на 2010-2020 роки", "Аержавну стратегію регіонального розвитку на період до 2020 року", "Стратегію сталого розвитку "Україна 2020". Зокрема у Стратегії національної модернізації країни "Україна 2020", яка прийнята у 2011 році, основними напрямами підвищення конкурентоспроможності України названі такі, формування громадянського суспільства та реформування системи державного управління, підвищення якості освіти і охорони здоров'я, енергетична безпека, наука та інноваційний розвиток, сільське господарство та продовольча безпека [9].

Інші стратегічні документи, які прийняті пізніше, доповнюють і розширюють окремі пріоритетні напрями розвитку держави та підвищення її конкурентоспроможності. Аля прикладу, схвалена Указом Президента України Стратегія сталого розвитку "Україна 2020" спрямована на стабілізацію техногенного навантаження на природне середовище, вирішення низки екологічних питань, реалізацію програми енергоефективності, реформування захисту інтелектуальної власності [1].

Проте, як зазначають фахівці, при розробці згаданих стратегічних документів допущені певні недоліки, як-от загальний описовий характер, відсутність конкретних механізмів реалізації, фрагментарність та не комплексність, що значно ускладнює їх реалізацію. Ао цього слід додати певну перевантаженість такого роду документів завданнями, які не є ключовими чи які досягти проблематично. Так, згадувана Стратегія сталого розвитку "Україна 2020" передбачала здійснення 62 реформ, що само по собі розпилює увагу, зусилля і ресурси відповідних державних інституцій та ускладнює їі реалізацію. Аля порівняння, Китай, свого часу, проголосив і реалізовував стратегію чотирьох реформ, які розтяглися у часі більше ніж на 30 років. Крім того, у вітчизняній Стратегії сталого розвитку надзвичайно завищеними виявилися прогнозовані параметри стратегічних індикаторів реалізації стратегії (табл. 3).

Якщо порівняти параметри стратегічних індикаторів, які передбачалось досягти до 2020 року і їх фактичне значення на період розробки Стратегії у 2015 році, то стає зрозуміло, що у тих соціально-економічних реаліях, у яких перебувала і зараз перебуває Україна, ні один із перерахованих індикаторів за п'ять років не міг бути досягнутим. Це підтверджують, зокрема, їх фактичні значення, досягнуті у 2018 році.

\section{Таблиця 3. Передбачувані та фактичні параметри стратегічних індикаторів реалізації Стратегії сталого розвитку "Україна 2020"}

\begin{tabular}{|c|c|c|c|c|}
\hline \multirow[t]{2}{*}{$\begin{array}{l}\text { № } \\
\text { п/п }\end{array}$} & \multirow[t]{2}{*}{ Стратегічний індикатор } & \multirow{2}{*}{$\begin{array}{l}\text { Прогноз } \\
\text { на } 2020 \text { p. }\end{array}$} & \multicolumn{2}{|c|}{$\begin{array}{c}\text { Фактичні } \\
\text { параметри }\end{array}$} \\
\hline & & & 2015 & 2018 \\
\hline 1 & $\begin{array}{l}\text { Рейтинг Світового банку } \\
\text { «Doing Business», місце }\end{array}$ & $\begin{array}{l}\text { Ввійти до } \\
30 \text { країн }\end{array}$ & 96 & 71 \\
\hline 2 & $\begin{array}{l}\text { Кредитний рейтинг } \\
\text { України }\end{array}$ & $\begin{array}{l}\text { Не нижче } \\
\text { «BBB» }\end{array}$ & $« \mathrm{CCC}+»$ & «B» \\
\hline 3 & $\begin{array}{l}\text { Індекс глобальної } \\
\text { конкурентоспроможності, } \\
\text { WEF, місце }\end{array}$ & $\begin{array}{l}\text { Ввійти до } \\
40 \text { країн }\end{array}$ & 79 & 81 \\
\hline 4 & $\begin{array}{l}\text { ВВП на душу населення, } \\
\text { дол. США }\end{array}$ & 16000 & 2115 & 3100 \\
\hline 5 & $\begin{array}{l}\text { Чисті надходження } \\
\text { прямих інвестицій за } \\
\text { 2015-2020 роки, млрд } \\
\text { дол. США }\end{array}$ & 40 & 5,3 & 2,5 \\
\hline 6 & $\begin{array}{l}\text { Індекс сприйняття } \\
\text { корупції, місце }\end{array}$ & $\begin{array}{l}\text { Ввійти до } \\
50 \text { кращих } \\
\text { країн }\end{array}$ & 130 & 120 \\
\hline
\end{tabular}

Ажерело: розроблено авторами на основі $[1 ; 11]$.

Очевидно, що при розробці такого роду документів державним інституціям слід враховувати місце України у глобальній конкурентоспроможності за окремими складовими i, спираючись на сильніші позиції, розробляти заходи для посилення слабших. Більше того, слабість державних інституцій є чи не головною проблемою при реалізації розроблених стратегічних програм. По суті, жодна із перерахованих у таблиці 2 стратегій не була до кінця реалізована, що є однією із причин стабільно низького рейтингу України у глобальній конкурентоспроможності.

Головними інструментами, які повинні забезпечити реалізацію стратегій розвитку держави є, як уже відмічалось, державні цільові програми. Так, у 2018 році в Україні діяло 14 Аержавних цільових програм [12]. Найбільш масштабними із них за обсягами фінансування $€$ Аержавна цільова економічна програма розвитку автомобільних доріг загального користування на 2013-2018 роки - 39,2 млрд грн, Аержавна цільова соціальна програма розвитку фізичної культури і спорту на період до 2020 року - 6,0 млрд грн та Загальнодержавна цільова програма розвитку водного господарства та екологічного оздоровлення басейну річки Аніпро на період до 2021 року - 5,8 млрд грн Аля порівняння зазначимо, що у 2015 році Аержавних цільових програм було 38, у 2016 році - 29, у 2017 році - 24.

Аналіз виконання Аержавних цільових програм за фінансуванням протягом останніх трьох років показує що ні в одному році фінансування не було надано у повному обсязі. Зок- 
Таблиця 4. Стан фінансування державних цільових програм по роках

\begin{tabular}{|c|c|c|c|c|}
\hline & & 2015 & 2016 & 2017 \\
\hline \multirow{2}{*}{$\begin{array}{l}\text { Кількість } \\
\text { державних } \\
\text { цільових } \\
\text { програм }\end{array}$} & план & 38 & 29 & 24 \\
\hline & факт & 29 & 23 & 18 \\
\hline \multirow{2}{*}{$\begin{array}{l}\text { Фінансування } \\
\text { всього, млрд грн }\end{array}$} & план & 197,4 & 79,9 & 86,5 \\
\hline & факт & 51,9 & 25,1 & 15,1 \\
\hline \multirow{2}{*}{$\begin{array}{l}\text { у т. ч.: } \\
\text { за рахунок } \\
\text { державного } \\
\text { бюджету }\end{array}$} & план & 44,3 & 44,6 & 47,1 \\
\hline & факт & 29,8 & 18,5 & 9,5 \\
\hline \multirow{2}{*}{$\begin{array}{l}\text { за рахунок } \\
\text { місцевих } \\
\text { бюджетів } \\
\end{array}$} & план & 8,2 & 3,4 & 6,6 \\
\hline & факт & 1,6 & 1,3 & 3,1 \\
\hline \multirow{2}{*}{$\begin{array}{l}\text { За рахунок } \\
\text { iнших джерел }\end{array}$} & план & 144,9 & 31,9 & 32,8 \\
\hline & факт & 20,5 & 5,3 & 2,5 \\
\hline
\end{tabular}

Ажерело: розроблено на основі [13].

рема у 2015 році ці програми були профінансовані на 26,3 \% від запланованого, у 2016 році на $31,5 \%$, у 2017 році - на 17,5 \% (табл. 4). Звичайно, їх виконання, за таких умов, стало надзвичайно проблематичним.

Про це свідчать, зокрема, результати моніторингу виконання державних цільових програм за 2017 рік, здійсненого Міністерством економічного розвитку і торгівлі України. У ньому вказано на наступні системні недоліки:

1. Аержавні цільові програми так і не стали дієвим та ефективним інструментом розв'язання найважливіших проблем розвитку держави, окремих галузей економіки або адміністративно-територіальних одиниць. Вони виконують роль "формального" документу з декларацією про наміри щось зробити".

2. У рамках планування та використання коштів державного бюджету не дотримуються в повному обсязі принципи пріоритетності вирішення проблеми. Питання досягнення програмних цілей не $є$ основним при розподіленні бюджетних коштів.

3. Прогнозні обсяги фінансових ресурсів програми, у тому числі коштів державного бюджету, не узгоджуються з реальними можливостями їх фінансування.

4. Всупереч вимогам пункту 29 Порядку програми не містять методики оцінки ефективності ї̈ виконання, що повинна бути розроблена державним замовником з урахуванням специфіки програми та кінцевих результатів.

5. 3 боку державних замовників має місце формальний підхід до виконання вимог чинного законодавства у сфері розроблення та виконання державних цільових програм.

6. Незадовільне звітування державних замовників: недотримання строків подання, інформація надається не в повному обсязі та не за всіма виконавцями.
7. Відсутня можливість для здійснення контролю з боку громадськості [13].

Aле якщо проаналізувати моніторингові звіти за минулі роки (2015-2016), то перелік системних недоліків, на які вказує у них Міністерство економічного розвитку i торгівлі, практично співпадає із переліком 2017 року. Це свідчить про те, що державні цільові програми, на жаль, ще не стали дієвим інструментом реалізації державних стратегій, спрямованих на підвищення глобальної конкурентоспроможності України. Вони дійсно, часто, виконують роль "формального документа", який мало до чого зобов'язує відповідні державні інституції і посадових осіб. Очевидно, необхідно значно підвищувати відповідальність як розробників програм за якість їх розробки у частині відповідності реальним можливостям фінансування, так i виконавців за неухильне дотримання визначених обсягів і термінів виконання програм.

\section{В ИСНОВКИ ТА ПЕРСПЕКТИВ И ПОДАЛЬШИХ ДОСЛІДЖЕНЬ}

Підвищення конкурентоспроможності національної економіки залишається однією із головних проблем, що постають перед українською державою. Ефективним механізмом вирішення цієї проблеми $є$ розробка відповідної державної стратегії, чи множини взаємозв'язаних стратегій та цільових програм, спрямованих на їх реалізацію. Водночас стратегії, які розроблялись протягом останніх років, за оцінкою фахівців, відрізнялись певною декларативністю, фрагментарністю, відірваністю від реальної соціально-економічної ситуації та можливостей національної економіки, що робило проблемним досягнення визначених у них цілей. Відповідно, державні цільові програми, спрямовані на підвищення конкурентоспроможності національної економіки, не стали дієвими інструментами реалізації цих стратегій. Це ставить перед науковцями та органами державної влади нові завдання, спрямовані як на вдосконалення методології і методики розробки відповідних стратегій та цільових програм, так і практики з їх реалізації.

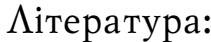

1. Указ Президента України "Про Стратегію Сталого розвитку "Україна-2020": http:// www.President.gov.ua/documents/18688.html

2. Герасимчук В.Г. Відповідальність і компетентність - основні принципи програмного підходу в управлінні: http//ev.fmm.kpi.ua/ article/view/108777/103720 
3. Стеблянко I.О. Програмно цільове управління в системі стійкого розвитку національної економіки. Інвестиції: практика та досвід. 2015. № 20 , с. $38-42$

4. Закон України "Про держані цільові програми" від 18. 04. 2004 року зі змінами і доповненнями, № 1621-IУ: https://zakon.rada.gov.ua/ laws/show/1621-15

5. Аідух Н. Глобальні індекси конкурентоспроможності національних економік. Економічний аналіз. 2012. Т. 10(1). С. 133-136.

6. (12) Рейтинг конкурентоспроможності економік країн світу - 2017/2018: https:// uteka.ua/publication/Rejting-konkurentosposobnosti-ekonomik-stran-mira-20172018

7. Позиція України в рейтингу країн світу за індексом глобальної конкурентоспроможності 2017-2018: http://edclub.com.ua/anality$\mathrm{ka} /$ pozyciya-ukrayiny-v-reytyngu-krayin-svituza-indeksom-globalnoyi konkurentospromozhnosti-2

8. Аипов В.В. Конкурентна стратегія розвитку України в умовах глобалізації. Економіка України, 2018. - № 3, с. 21-35.

9. Стратегія національної модернізації країни "Україна 2020": http:old.radakmu.org.ua/file/ Strategy\%202020.doc

10. Юринець 3.В. Інноваційні стратегії в системі підвищення конкурентоспроможності економіки України: дис. ... А-ра. екон. наук: 08.00.03. Аьвів, 2016. 519 с.

11. Офіційний веб-сайт Міністерства економічного розвитку і торгівлі України: http:// me.gov.ua/Documents/Detail?lang $=u k-U A \& i d=-$ 232ba380-67ec-4689-a90e-f67da7840f9e\&title=DoingBusiness

12. Перелік державних цільових програм, які діють у 2018 році: https://dostup.pravda.com.ua/request/32831/response/69678/attach/ $5 / 3033 \% 2007 \% 2015283 \% 2009$.pdf/

13 (19). Аержавні цільові програми. Офіціцйний веб-сайт Міністерства економічного розвитку і торгівлі України: http://me.gov.ua/ Documents/List?lang=uk-UA\&tag=DerzhavniTsiloviProgrami

\section{References:}

1. President of Ukraine (2015), Decree "About the Strategy of Sustainable Development "Ukraine-2020"', available at: http://www.President.gov.ua/documents/18688.html (Accessed 20 April 2019).

2. Herasymchuk, V.H. (2017), "Responsibility and competence - the basic principles of a programmatic approach in management", available at: http://ev.fmm.kpi.ua/article/view/ 108777/103720 (Accessed 20 April 2019).

3. Steblianko, I.O. (2015), "Programmatic target management in the system of sustainable development of the national economy", Investytsii: praktyka ta dosvid, vol. 20, pp. 38-42.

4. Verkhovna Rada of Ukraine (2004), The Law of Ukraine "About state target programs", available at: https://zakon.rada.gov.ua/laws/ show/1621-15 (Accessed 20 April 2019).

5. Didukh, N. (2012), "Global indices of competitiveness of national economies", Ekonomichnyj analiz, vol. 10 (1), pp. 133-136.

6. uteka.ua (2019), "Competitiveness rating of the economies of the world - 2017/2018", available at: https://uteka.ua/publication/Rejting-konkurentosposobnosti-ekonomik-stran-mira-20172018 (Accessed 20 April 2019). (12) Рейтинг конкурентоспроможності економік країн світу - 2017/ 2018:

7. Economic Discussion Club (2019), "Ukraine's position in the world ranking according to the Global Competitiveness Index 2017-2018", available at: http://edclub.com.ua/analityka/ pozyciya-ukrayiny-v-reytyngu-krayin-svitu-zaindeksom-globalnoyikonkurentospromozhnosti-2 (Accessed 20 April 2019).

8. Lypov, V.V. (2018), "Competitive strategy of Ukraine's development in the conditions of globalization", Ekonomika Ukrainy, vol. 3, pp. 21-35.

9. Council of Entrepreneurs under the Cabinet of Ministers of Ukraine (2015), "Ukraine 2020 national modernization strategy", available at: http://old.radakmu.org.ua/file/Strategy\%202020.doc (Accessed 20 April 2019).

10. Yurynets', Z.V. (2016), "Innovative Strategies in the System of Increasing the Competitiveness of the Ukrainian Economy", Abstract of Ph.D. dissertation, Economy, Lviv, Ukraine.

11. Ministry of Economic Development and Trade of Ukraine (2019), available at: http:// me.gov.ua/Documents/Detail?lang=uk-UA\&$\mathrm{id}=232$ ba $380-67$ ec-4689-a 90 e-f67da 7840 f9e\&title=DoingBusiness (Accessed 20 April 2019).

12. pravda.com.ua (2019), "List of state target programs in force in 2018", available at: https:// dostup.pravda.com.ua/request/32831/response/ 69678/attach/5/3033\%2007\%2015283\%2009.pdf (Accessed 20 April 2019).

13. Ministry of Economic Development and Trade of Ukraine (2019), "State Target Programs", available at: http://me.gov.ua/Documents/ List?lang $=\mathrm{uk}-\mathrm{UA} \& \mathrm{tag}=$ DerzhavniTsiloviProgrami (Accessed 20 April 2019).

Стаття надійшла до редакиї 24.04.2019 p. 
УAK 338.439.6:338.2

О. Т. Аевандівський, к. е. н., Аоцент, Прикарпатський національний університет імені В. Стефаника ORCID iD: 0000-0002-5819-8377

DOI: $10.32702 / 2306-6792.2019 .9 .10$

\title{
ЗАРУБІЖНИЙ АОСВІА ПІАВИЩЕННЯ ІНВЕСТИЦІЙНОЇ АКТИВНОСТІ СІАЬСЬКОГОСПОААРСЬКИХ ПІАПРИЕМСТВ
}

\author{
O. Levandivskyi, \\ $\mathrm{PhD}$ of Economics, Associate Professor of the Department of Finance, \\ Vasyl Stefanyk Precarpathian National University, Ivano-Frankivsk
}

\section{FOREIGN EXPERIENCE IN INCREASING THE INVESTMENT ACTIVITY OF AGRICULTURAL ENTERPRISES}

Узагальнення результатів дослідження дозволяє виділити три основні напрями підвищення привабливості та активності інвестиційної діяльності в сільськогосподарських підприємствах: зміна обсягів і структури інвестицій, підвищення рентабельності операційної Аіяльності та зниження середньозваженої вартості капіталу, що використовується.

Вищеперераховані напрями тісно взаємопов'язані між собою. При цьому провідне значення має рентабельність інвестованого капіталу, високий рівень якого знижує гостроту проблеми фінансування. У цьому випадку генерування прибутку буде достатнім Аля залучення як власних, так і позичкових ресурсів.

Аослідження свідчить, що сільське господарство потребує Аієвих заходів щодо згладжування коливань цін на його продукцію. Висока чутливість рентабельності до змін цін підвищує рівень ризику інвестування капіталу у галузь, знижує передбачуваність відАачі на вкладений капітал.

ОАним із інструментів забезпечення стабілізації цін на сільськогосподарську продукціює державні фінансові та товарні інтервенції. Основною метою проведення інтервенцій $є$ забезпечення доходів сільськогосподарських товаровиробників, достатнього Аля розширеного відтворення і стабілізація цін на ринку.

В умовах низької рентабельності сільськогосподарського виробництва формування власних резервів підприємствами явно недостатньо для покриття втрат у випадку настання ризикової події. У цій ситуації необхідно залучати зовнішні джерела фінансування у непередбачуваних ситуаціях. Разом із тим, до цього часу залишається слабко розвиненою біржова торгівля, що стримує використання фінансових інструментів хеджування ризиків. На нашу думку, вирішення вказаних недоліків дозволить знизити ризики інвестування у галузь.

Аослідженням встановлено, що до недавнього часу участь держави в підтримці сільського господарства у країні велася піА різними ідеологічними лозунгами - віА "антикризових заходів", "підтримка доходів" і "порятунку сімейного фермерства" до "захисту США від нечесних форм конкурентної боротьби". Відповідно і фінансові вливання Аержави в сільське господарство визначалися на ранніх етапах як "субсидії", "безповоротні кредити", "Аотації", "Аопомога" і т.A.

Узагальнимо основні причини, що зумовили визнання урядом та суспільством такого підходу до державної підтримки сільського господарства. По-перше, рішення Конгресу 80-90-х років і хіА реалізації 50 державних сільськогосподарських програм свідчить про перегляА Аеяких засаА зАійснення державної підтримки галузі. По-друге, фермерство США все у більшій мірі покладається уже не на власні сили, досвіА і знання, а на послуги держави щодо вирішення таких важливих питань, як оцінка кон'юнктури ринку, оптимізація структури і обсягів виробництва, можливостей використання інноваційних розробок, маркетингових інструментів і т.A. По-третє, із позиції американського споживача сільське господарство країни є найбільш продуктивним у світі, оскільки в середньому американці лише $11 \%$ своїх доходів витрачають на харчування, що значно менше, ніж у інших провідних країнах світу.

Summarizing the results of the study allows to distinguish three main directions for increasing the attractiveness and activity of investment activity in agricultural enterprises: changes in volumes and structure of investments, increase of profitability of operating activity and decrease in average weighted value of used capital.

The above-mentioned directions are closely interconnected. At the same time, the profitability of the invested capital is of key importance, the high level of which reduces the urgency of the financing problem. In this case, the generation of profits will be sufficient to attract both own and borrowed resources. 
The study shows that agriculture needs effective measures to smooth the fluctuations in prices for its products. The high sensitivity of profitability to changes in prices increases the level of risk of investing capital in the industry, reduces the predictability of return on invested capital.

One of the tools to stabilize prices for agricultural products is government financial and commodity interventions. The main purpose of the intervention is to provide revenues for agricultural producers, sufficient for expanded reproduction and stabilization of prices in the market.

In conditions of low profitability of agricultural production, the formation of own reserves enterprises is clearly not enough to cover losses in the event of a risk event. In this situation, it is necessary to involve external sources of financing in unforeseen situations. At the same time, so far, poorly developed stock trading remains, which holds back the use of financial hedging instruments. In our opinion, solving these shortcomings will reduce the risks of investing in the industry.

The study found that until recently, the state's participation in agricultural support in the country was conducted under various ideological slogans - from "crisis measures", "income support" and "rescue of family farming" to "protecting the United States from dishonest forms of competition." Accordingly, the financial infusions of the state in agriculture were defined at an early stage as "subsidies", "non-repayable loans", "subsidies", "aid", etc.

We will generalize the main reasons that led the government and society to recognize that approach to state support to agriculture. First, the decision of the Congress of the 80's and 90 's and the progress of the implementation of 50 state agricultural programs indicates a revision of some of the principles of state support to the industry. Secondly, US agriculture is increasingly reliant not on its own strength, experience and knowledge, but on state services to address such important issues as market conditions assessment, optimization of structure and volume of production, opportunities for using innovative development, marketing tools, etc. Thirdly, from the position of the American consumer, agriculture is the most productive in the world, since Americans spend only $11 \%$ of their income on food, which is much lower than in other leading countries of the world.

Ключові слова: сільськогосподарське підприємство, фермер, державна підтримка, інвестичійна діяльність, капітал.

Key words: agricultural enterprise, farmer, state support, investment activity, capital.

\section{ПОСТАНОВКА ПРОБЛЕМИ}

Інвестиції відіграють кдючову роль у розвитку аграрного сектора. Саме ця галузь вважається однією з найменш інвестиційно привабливих в Україні, що обумовлено не тільки об'єктивними причинами, як-от висока капіталомісткість галузі, сильна залежність від природно-кліматичних умов, значні постійні витрати, але і суб'єктивними причинами, головна з яких - неефективність управління.

Питання залучення інвестицій в аграрний сектор до сих пір не вирішено. Очевидно, що інвестиційний процес у цій сфері необхідно вдосконалювати. У зв'язку з цим вважаємо за доцільне проаналізувати досвід розвинених країн в питаннях державної підтримки та регулювання аграрної галузі. Саме державне регулювання створює нормативно-правові та соціально-економічні умови для розвитку аграрної галузі, а також для задоволення потреб населення країни в якісних і безпечних продуктах харчування за соціально прийнятними цінами.

\section{АНАЛІЗ ОСТАННІХ ДОСЛІДЖЕНЬ І ПУБЛІКАЦІЙ}

Проблеми інвестиційної діяльності відображені у працях багатьох вчених-економістів зарубіжних та вітчизняних шкіл. Питанням інвестування присвячені роботи провідних зарубіжних вчених: Аж. Кейнса, П. Массе, К.Р. Мак-

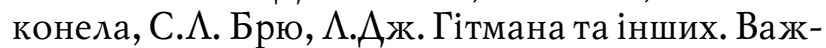

ливе місце ці питання займають у працях вітчизняних дослідників: I.О. Бланка, В.М Гриньової, О.І. Аація, Т.В. Майорової, А.А. Пересади, В.С. Пономаренка, В.Г. Федоренка, В.П. Савчука, В.Я. Шевчука, П.С. Рогожина та інших. Особливості розвитку та вдосконалення інвестування агропромислового комплексу відображені в роботах С.А. Гуткевич, О.І. Гуторова, М.I. Кісіля, П.Т. Саблука, В.М. Трегобчука та інших.

Віддаючи належне науковій та практичній цінності праць вчених, та розглянувши опубліковані за останні роки роботи в області інвестиційної діяльності можна зробити висновок, що не всі її науково-методичні та практичні аспекти отримали необхідне відображення.

\section{МЕТА ДОСЛІДЖЕННЯ}

Метою дослідження є розробка практичних рекомендацій на основі узагальнення зарубіжного досвіду щодо підвищення інвестиційної активності сільськогосподарських підприємств.

\section{ВИКЛАД ОСНОВНОГО МАТЕРІАЛУ ДОСЛІДЖЕННЯ}

Узагальнення результатів дослідження дозволяє виділити три основні напрями підвищення привабливості та активності інвестиційної діяльності в сільськогосподарських підприємствах: зміна обсягів і структури інвестицій, підвищення рентабельності операційної діяль- 
ності та зниження середньозваженої вартості капіталу, що використовується.

Вищеперераховані напрями тісно взаємопов'язані між собою. При цьому провідне значення має рентабельність інвестованого капіталу, високий рівень якого знижує гостроту проблеми фінансування. У цьому випадку генерування прибутку буде достатнім для залучення як власних, так і позичкових ресурсів.

Низький рівень віддачі на вкладений капітал, навпаки, змушує інвестора оптимізувати структуру джерел його залучення. Однак в умовах низького рівня розвитку інститутів фінансової інфраструктури та нестабільності економіки вирішувати цю задачу достатньо складно, оскільки кількість джерел залучення капіталу дуже обмежена. Як правило, це низьколіквідні кошти із високою процентною ставкою (банківський кредит). У таких умовах опинилися сільськогосподарські підприємства на сучасному етапі розвитку економіки. Низький рівень рентабельності не дозволяє їм у повному обсязі використовувати у необхідному обсязі ні власні, а ні позичкові кошти. Тому при розробці заходів по підвищенню інвестиційної активності першочергового значення набувають програми щодо підвищення і стабілізації прибутковості сільськогосподарського виробництва при активній участі держави.

Питання про підвищення рівня рентабельності виробничої діяльності серед науковців $є$ відкритим і дискусійним. На нашу думку, для забезпечення росту віддачі інвестованого капіталу і переведення сільськогосподарський підприємств на принципи самофінансування необхідно, щоб у довгостроковій перспективі виконувалася наступна нерівність:

$\mathrm{ROC}>\mathrm{Tp}, \mathrm{ROC}>\mathrm{WACC}$

де Тр - темп росту цін на ресурси; WACC середньозважені затрати на залучення капіталу; ROC - рентабельність інвестованого капіталу.

Зазначимо, перша умова $є$ необхідною за умови відсутності у сільськогосподарських підприємствах вільного доступу до позичкових Ажерел. Якщо можливості залучати позичковий капітал необмежені, то необхідною умовою Аля росту вартості інвестованого капіталу буде перевищення рентабельності власного капіталу інвестора (ROE) та рівня інфляції (Tp).

Першочергового значення має перша нерівність. Ї̈і виконання свідчить про те, що створений прибуток від використання капіталу перевищує втрати від його знецінення у результаті росту цін, що дозволяє підприємствам вести просте відтворення і накопичувати капі- тал для нарощення виробничих потужностей. Якщо ріст цін випереджує ріст капіталу у вигляді прибутку, підприємства вимушені залучати капітал, щоб зберегти обсяги виробництва на попередньому рівні. Якщо така умова не виконується у довгостроковому періоді, то якою би низькою не була плата за капітал, його вартість із часом буде знижуватися. Тому спроби держави по здешевленню позичкових коштів Аля підприємств галузі може бути малоефективною.

Аруга нерівність повинна виконуватися як у довгостроковому, так і короткостроковому періодах. Це дозволить погашати затрати на залучення капіталу і створювати додаткову вартість для інвестора. Однак, якщо перша умова не виконується у довгостроковому періоді, то через деякий час друга умова також перестає виконуватися. Хронічна нестача коштів, зумовлена більш стрімким ростом цін на матеріально-технічні ресурси порівняно із прибутком, що зумовить необхідність нарощувати позичковий капітал та збільшувати його частку у структурі майна. Це, у свою чергу, загострює проблему доступу сільськогосподарський підприємств до позичкового фінансування i підвищує ризик банкрутства підприємства [1].

Зазначимо, що діючі важелі державнӧ̈ підтримки не згладили коливань рентабельності операційної діяльності сільськогосподарських товаровиробників. Останні можуть бути наслідком наявності у галузі високих ризиків, що вимагає розробки програм для їхьої нейтралізації та зниженню.

Аослідження свідчить, що сільське господарство потребує дієвих заходів щодо згладжування коливань цін на його продукцію. Висока чутливість рентабельності до змін цін підвищує рівень ризику інвестування капіталу у галузь, знижує передбачуваність віддачі на вкладений капітал.

Одним із інструментів забезпечення стабілізації цін на сільськогосподарську продукцію $€$ державні фінансові та товарні інтервенції. Основною метою проведення інтервенцій $є$ забезпечення доходів сільськогосподарських товаровиробників, достатнього для розширеного відтворення і стабілізація цін на ринку [2].

Отже, через проведення фінансових і товарних інтервенцій була прийнята спроба стабілізувати ціни, але значного результату вона не принесла. У цілому, незважаючи на інтервенції строкатість цін на сільськогосподарську продукцію збереглася, що можна пояснити його низькою ефективності. Це зумовлено цілим рядом недоліків при його функціонуванні. По- 
перше, інтервенції мають не постійний, а імпульсивний характер. Вони починаються у той момент, коли ринкова ціна відхиляється від граничної заданої величини. По-друге, реалізація інтервенцій має бюрократичний характер і вимагає численних узгоджень за цінами, обсягами та джерелами фінансування. По-третє, обсяги інтервенцій досить незначні, щоб істотно впливати на ринкову ситуацію.

Разом із тим, існують й інші способи протидії ризику: хеджування і передача ризику. Перший представляє собою систему заходів по створенню умов мінімізації втрат у результаті настання ризикової події. На практиці даний спосіб здійснюється через створення різних резервів, наприклад, резервного капіталу, резервів за сумнівними боргами і т.д. Аналогічним чином відбувається резервування із використанням фінансових інструментів на фінансових ринках - опціонів і ф'ючерсів.

В умовах низької рентабельності сільськогосподарського виробництва формування власних резервів підприємствами явно недостатньо для покриття втрат у випадку настання ризикової події. У цій ситуації необхідно залучати зовнішні джерела фінансування у непередбачуваних ситуаціях. Разом із тим, до цього часу залишається слабко розвиненою біржова торгівля, що стримує використання фінансових інструментів хеджування ризиків. На нашу думку, вирішення вказаних недоліків дозволить знизити ризики інвестування у галузь.

Аругий спосіб протидії ризику - його передача реалізується за допомогою страхування. Нині у сільському господарстві реалізується програма по страхуванню урожаю при фінансовій підтримці держави. Однак, як свідчить досвід провідних країн світу, у сільському господарстві використовуються також програми страхування або стабілізації доходів товаровиробників.

Заслуговує на увагу вітчизняної практики досвід Канади, де до 2004 р. існувала добровільна програма стабілізації чистого доходу (NISA). Фермери, які беруть участь у програмі, можуть робити вкладення на депозит, сума якого доповнювалася такою ж сумою через фінансування федерального і регіонального бюджетів. На загальну суму грошових коштів виплачується процент фінансовими інститутами, які зберігають депозити, а також урядом. При зниженні прибутку нижче середньорічного рівня за останні п'ять років учасники могли знімати із рахунку кошти для компенсації втрати, що виникла [3].

На зміну такої програми прийшла Канадська програма стабілізації доходу фермера
(CAIS). Ця програма переслідує протидії зниженню фермерського доходу. Фермер одержує компенсацію, якщо його дохід у поточному році є нижчим середньої його величини за останні декілька років. При цьому величина підтримки залежить від вибраного рівня захисту. Якщо фермер вибирає максимальний рівень захисту, то він може одержати до 22\% застрахованого прибутку. Його розмір визначається як середня величина за три із останніх п'яти років (роки із найбільшою і найменшою сумою прибутку виключаються). Поточний максимальний внесок товаровиробника становить 4,5 канд. дол. на кожну 1000 кан. дол. застрахованого прибутку (але не менше 10 тис. кан. дол) плюс адміністративні витрати у розмірі 55 канд. дол, а при настанні страхового випадку держава компенсує 70\% зниження прибутку у поточному періоді [4].

Заслуговує на увагу вітчизняної практики досвід державної підтримки аграрного сектору економіки США, де майже 70 років поспіль держава намагається регулювати процеси відтворення у сільському господарстві. Важливою складовою такого регулювання є фінансово-кредитна підтримка.

Фінансування здійснюється шляхом виділення із державного бюджету асигнувань, які направляються на реалізацію цільових програм, які мають національне значення. На федеральному рівні виділяються виділяють дві цільові програми: стабілізації доходів і наукове забезпечення.

Окрім цього, на федеральному рівні діє більше 10 міжгалузевих цільових програм, які у різній степені торкаються інтересів сільського господарства і фермерів. Ао них відносять, такі програми, як консервація земель та вилучення земель, продовольча допомога бідним верствам населення, маркетинг та інспекція, соціальний розвиток сільської місцевості та інші.

Бюджетні кошти, які розподіляються під ці програми, контролює на 80\% міністерство сільського господарства США через Товарнокредитну корпорацію, Адміністрацію по справам фермерів та інші фінансово-кредитні організації. Інші частку - $20 \%$ розподіляють через штати та місцеві органи управління [5, с. 7].

Найбільш пріоритетною програмою є державна система підтримки цін, яка тісно пов'язана із програмою консервації та вилучення із обороту сільськогосподарських угідь. Витрати Товарно-кредитної корпорації на цю програму становили в останні роки від 30 до 50\% усіх 
витрат федерального бюджету на сільські господарства.

Нині бюджетним фінансуванням за програмою підтримки цін і доходів охоплено лише 1/3 американських ферм, причому $70 \%$ цих коштів одержують фермери із річним обсягом товарної продукції 100 тис. доларів і вище. 3 метою вирівнювання стану фермерів у питаннях бюджетного фінансування із 1986 р. введено обмеження дотування у розмірі 50 тис. доларів на одну ферму [6].

Нині у цій країні активно використовується програма середньострокових кредитів у рамках Закону про продовольчу підтримку з метою посилення орієнтації країн-імпортерів на тривалі закупівлі американської сільськогосподарської продукції.

Починаючи із 1986 р. держава стимулює фермерів продавати свою продукцію на зовнішніх ринках, компенсуючи їм різницю між ціною реалізації, тобто світовою ціною і заставною ставкою у вигляді експортної компенсаційної надбавки. Нині частка США у світовому експорті багатьох видів сільськогосподарської продукції становить від 40\% до $60 \%$.

Нині із усіх витрат на сільське господарство США $60 \%$ припадає на реалізацію програми стабілізації доходів фермерів. Ця програма, у свою чергу, поділяється на наступні програми: "Підтримка цін і доходів", "Страхування урожаю", "Сільськогосподарський кредит". Якщо у 1995 р. на них було виділено 15,7; 0,4 і 6,1 млрд доларів, відповідно, то у 2006 р. такого роду витрати помітно зросли: підтримка цін і прямі виплати фермерам - 28,07 млрд доларів; страхування сільськогосподарських підприємств 4,1 млрд доларів; гранти фермерам - 3,8 млрд доларів та інші [7, с. 12].

Фінансування цільових програм дозволяє за допомогою економічних важелів регулювати виробництво і розподіл певних видів сільськогосподарської продукції і продовольства, тобто впливати на фермерські господарства через субсидії, ціни, кредити, дотації, тим самим впливаючи на економіку ферм. Виходячи із цього, механізми і масштаби фінансування, їх функціональна направленість залежать від економічної ситуації, яка складається на внутрішньому ринку США і світовому аграрному ринку.

Підвищення ефективності сільськогосподарського виробництва зумовлює необхідність у позичковому капіталі для фінансування поточних і капітальних затрат. Саме тому важливим у системі державного регулювання сільськогосподарського виробництва США $є$ функціонування системи сільськогосподарського кре- диту. Ця система впродовж усієї історії вирішувала одні й ті ж самі задачі: надання фермерам і підприємства агробізнесу можливості одержання кредитних ресурсів на пільгових умовах; активне залучення у систему кредитування грошових коштів фермерів, фермерських кооперативів, а також приватного капіталу фірм і компаній агробізнесу.

Зазначимо, що у США до основної групи кредитних закладів, які формують систему сільськогосподарського кредиту, входять комерційні банки, страхові компанії, система фермерського кредиту, Адміністрація по справам фермерів, Товарно-кредитна корпорація та ін., усього понад 800 банків і асоціацій.

Сільськогосподарські товаровиробники використовують позичкові кошти для різних цілей, їх можна поділити на позики для придбання рухомого і нерухомого майна. Так, фермери на пільгових умовах можуть одержувати позики на придбання техніки і обладнання, поповнення стада, кормів, насіння і добрив, на погашення боргів по рухомому майну. Розмір позики становить максимум 200 тис. доларів на термін від 1 до 7 років. У окремих випадках кредит може становити до 400 тис. доларів Процентні ставки визначаються базовою ставкою Центрального банку США [8].

Пільгові умови кредитування передбачені спеціально для молодих людей на створення та облаштування ферм. Право на такий кредит мають молоді особи, які входять до організації "Майбутні фермери США" або інших подібних організацій.

Власники ферм, які постраждали від стихійного лиха, мають право на одержання надзвичайного кредиту (максимум 500 тис. доларів) під 4,5\% річних.

Найбільші пільги надаються біднішим фермера і сільським жителям у рамках програми по покращенню житлових умов. Процентна ставка у цьому випадку дорівнює $1 \%$.

Значну роль у реалізації заходів державної підтримки в США відіграє Міністерство сільського господарства. Серед основних його функцій є підтримка сільського господарства, доходів фермерів і стабільності ринку. Бюджет даного Міністерства становить: у 2004 р. - майже 111 млрд доларів, у 2005 р. - близько 134 млрд доларів США, у 2006 р. - майже 130 млрд доларів США [7, с. 14].

Зазначимо, що величина цієї підтримки, є досить вагомою, оскільки складає більше $30 \%$ вартості продажів усієї сільськогосподарської продукції. Наведемо інший показник участі держави у сільгоспвиробництві - на кожен 
гектар оброблюваної ріллі в США нині припадає дотація у розмірі 410 дол. США у рік. У країні жодна інша галузь економіки не користується такою потужною державною підтримкою.

Аослідженням встановлено, що до недавнього часу участь держави в підтримці сільського господарства у країні велася під різними ідеологічними лозунгами - від "антикризових заходів", "підтримка доходів" і "порятунку сімейного фермерства" до "захисту США від нечесних форм конкурентної боротьби". Відповідно і фінансові вливання держави в сільське господарство визначалися на ранніх етапах як "субсидії", "безповоротні кредити", "дотації", "допомога" і т.д. Однак закон 1996 р. встановив; якщо фермер згоден із сільськогосподарському політикою уряду, то він "має право на державну підтримку незалежно від того, що він вирощує і який сьогодні рівень цін на його продукцію" [9]. Іншими словами, спрямування бюджетних інвестиційних коштів у цю галузь стало офіційним і підпорядкованим державним економічним механізмам регулювання.

Відповідно до нового сільськогосподарського закону "Про фермерську безпеку та інвестиції в сільську місцевість" (2002 р.) Уряд США продовжує субсидувати і розвиток сільських територій. Арібні і середні фермерські господарства отримують від держави на контрактній основі фінансову підтримку, незалежно від результатів їхньої господарської діяльності.

Узагальнимо основні причини, що зумовили визнання урядом та суспільством такого підходу до державної підтримки сільського господарства. По-перше, рішення Конгресу $80-90-x$ років і хід реалізації 50 державних сільськогосподарських програм свідчить про перегляд деяких засад здійснення державної підтримки галузі. Можна сказати, що у країні ведеться пошук шляхів ефективного захисту сільського господарства у ринкових умовах через посилення державного регулювання.

По-друге, фермерство США все у більшій мірі покладається уже не на власні сили, досвід і знання, а на послуги держави щодо вирішення таких важливих питань, як оцінка кон'юнктури ринку, оптимізація структури і обсягів виробництва, можливостей використання інноваційних розробок, маркетингових інструментів і т.А. I не випадково те, що у центральному апараті Міністерства сільського господарства США нині працюють 14 тис. співробітників, які обслуговують аграрну сферу економіки.
По-третє, із позиції американського споживача сільське господарство країни $є$ найбільш продуктивним у світі, оскільки в середньому американці лише $11 \%$ своїх доходів витрачають на харчування, що значно менше ніж у інших провідних країнах світу. Такий стан справ створює у населення країни позитивне відношення до виділення значних витрат на підтримку галузі, оскільки вона визначає рівень його життя.

Вивчення ієрархічної структури кооперативної системи у США дозволило встановити, що сформована система кредитування фермерів (Farm Credit System) є власністю банків та асоціацій, які до нього входять і володіють нею на кооперативній основі. Ця система кредитування складається із чотирьох регіональних банків, які надають фінансові фонди місцевим локальним асоціаціям позичальникам 80 Асоціаціям сільськогосподарського кредитування (Agricultural Credit Association) i 11 Федеральним земельним асоціаціям кредитування (Federal Land Credit Association). Саме локальні асоціації розміщують кредити серед сільських клієнтів, причому АСА спеціалізуються на коротко- - і середньостроковому кредитуванні, а FLCA - на довгостроковому.

Зазначимо, що до цієї системи входить Сільськогосподарський кредитний банк (Agricultural Credit Bank), який створено спеціально для обслуговування кредитних потреб сільськогосподарських кооперативів. Він надає усі види банківських послуг і фінансує також експорт сільськогосподарської продукції [10].

Вищеперераховані фінансові інститути пропонують кредитні ресурси сільськогосподарським товаровиробникам та їх кооперативам у всіх 50 штатах Америки. Нині обсяг наданих сільськогосподарськими кредитними установами країни складає понад 90 млрд доларів для більше півмільйону позичальників. Зазначимо, що грошові кошти для позик сільськогосподарські кредитні установи одержують під гарантії зі сторони Федеральної корпорації з фінансування банків системи кредитування фермерів (Federal Farm Credit Banks Funding Corporation). Позики сільськогосподарські кредитні установи підлягають страхуванню Страховою корпорацією системи кредитування фермерів (Farm Credit System Assistance Corporation).

Аослідженням встановлено, що в останні роки кредитні вкладення у сільськогосподарське виробництво були направлені, насамперед, на модернізацію і технічне переозброєння виробничого процесу. У зв'язку із цим, кредитні 
вкладення були сконцентровані на суміжних із аграрним сектором галузях - виробниках засобів виробництва і переробної промисловості.

\section{ВИСНОВКИ}

Проведений аналіз дозволяє зробити висновок, що виробничий потенціал аграрного сектора і його сталий розвиток в першу чергу залежать від того, наскільки ефективно держава регулює і стимулює інвестиційну активність сільськогосподарських товаровиробників. Аержаві не слід втручатися в їх діяльність, однак необхідно всіляко сприяти прийняттю необхідної законодавчої бази і забезпечувати економічну і правовий захист інвестованих ними коштів. Необхідно максимально розширити спектр державних гарантій, страхувати вкладаються кошти, що для інвесторів буде свідчити про ефективність і низьку ризикованість вкладень, а значить, забезпечить умови для сталого розвитку російського аграрного сектора.

Аля того щоб аграрний сектор став привабливим для інвесторів, необхідна активна державна участь у формі створення сприятливих ринкових механізмів, що знижують інвестиційні ризики, що підвищують приплив капіталу 3 інших галузей в аграрний сектор, що збільшують ефективність використання оборотних коштів і основних фондів, що сприяють перерозподілу між споживачами і виробниками ресурсів сільськогосподарського призначення.

\section{$\Lambda$ iтература:}

1. Борсук О.М. Методичні підходи до оцінки інвестиційної привабливості об'єктів вкладення капіталу / О.М. Борсук // Вісник Білоцерківського державного аграрного університету. - Біла Церква, 2010. - № 4. - С. 25-30.

2. Зарицька Н. Новий погляд на інвестиції в агробізнес / Н. Зарицька // Економіст. - 2018. - № 2. - C. 6-7.

3. MacRae, R.J., Hill, S.B., Henning, J. and Bentley, A.J. 2004. Policies, programs and regulations to support the transition to sustainable agriculture in Canada. American J. Alternative Agriculture 5(2):76-92.

4. Belhadji,B.,Gagne,S. And Roy,A. (2000). Profile of Canadian Agri-food Cooperatives (1986-1996). Co-operatives Secretariate. Ottawa, Ontario.

5. Michael J.H., Dillard J., Williams R. The Debt Finance Landscape for US. Farming and Farm Businesses, USDA, ERS, 2009. - 12 p.

6. Johnson J. Financial Characteristics of U.S. Farms, 1987, Agr. Inf. Bull. No. 525, USDA, ERS, 1987. - 28 p.
7. Dubman R. Farm Income and Costs: 2010 Farm Sector Income Forecast. USDA, ERS, 2010. $-16 \mathrm{p}$.

8. Аенега А. $\Lambda$. Інвестиції в інновації - запорука економічного зростання сільського господарства в Україні / А.А. Аенега, В.М. Чорнорибченко // Продуктивність агропромислового виробництва. - 2016. - № 28. - С. 8-14.

9. Горшков М.А. Інвестиції в процеси відтворення - ресурсний потенціал розвитку аграрного сектору / М.A. Горшков // Інвестиції: практика та досвід. - 2015. - № 5. C. $70-73$.

10. Farmer Cooperative Statistics 2005. RBS Service Report 46. Washington, D.C.: USDA, 2004. $-124 \mathrm{pp}$.

\section{References:}

1. Borsuk, O.M. (2010), "Methodological approaches to the estimation of investment attractiveness of investment objects of capital", Visnyk Bilotserkivs'koho derzhavnoho ahrarnoho universytetu, vol. 4, pp. 25-30.

2. Zaryts'ka, N. (2018), "A new look at investing in agribusiness", Ekonomist, vol. 2, pp. 6-7.

3. MacRae, R.J. Hill, S.B. Henning, J. and Bentley, A.J. (2004), "Policies, programs and regulations to support the transition to sustainable agriculture in Canada", American J. Alternative Agriculture, vol. 5 (2), pp. 76-92.

4. Belhadji, B. Gagne, S. and Roy, A. (2000), Profile of Canadian Agri-food Cooperatives (19861996). Co-operatives Secretariate, Ottawa, Ontario.

5. Michael, J.H. Dillard, J. and Williams, R. (2009), The Debt Finance Landscape for US, Farming and Farm Businesses, USDA, ERS, Washington, D.C., USA.

6. Johnson, J. (1987), "Financial Characteristics of U.S. Farms", Agr. Inf. Bull. vol. 525, USDA, ERS, Washington, D.C., USA.

7. Dubman, R. (2010), Farm Income and Costs: 2010 Farm Sector Income Forecast,USDA, ERS, Washington, D.C., USA.

8. Deneha, A.L. (2016), "Investing in innovation is the key to economic growth of agriculture in Ukraine", Produktyvnist' ahropromyslovoho vyrobnytstva, vol. 28, pp. 8-14.

9. Horshkov, M.A. (2015), "Investments in reproduction processes - resource potential of the agrarian sector development", Investytsii: praktyka ta dosvid, vol. 5, pp. 70-73.

10. USDA (2004), Farmer Cooperative Statistics 2005. RBS Service Report 46, USDA, Washington, D.C., USA.

Статта надійшла до редакиії 03.05.2019 p. 
Т. О. Меліхова, А. е. н., доцент, завідувач кафедри обліку, аналізу, оподаткування та аудиту, Інженерний інститут Запорізького національного університету

ORCID iD: 0000-0002-9934-8722

DOI: $10.32702 / 2306-6792.2019 .9 .17$

\section{МЕТОАИЧНІ ЗАСААИ ПРОВЕАЕННЯ ВНУТРІШНЬОГО КОНТРОАЮ РОЗРАХУНКІВ З ПОКУПЦЯМИ ТА ЗАМОВНИКАМИ ААЯ ПІАВИЩЕННЯ ЕФЕКТИВНОСТІ ФІНАНСОВО-ГОСПОААРСЬКОЇ АІЯ АЬНОСТІ ПІАПРИЕМСТВА}

\section{T. Melikhova,}

Doctor of Economic Sciences, Associate Professor, Head of the Department of Accounting, Analysis, Taxation and Audit, Engineering Institute Zaporizhzhya National University

METHODICAL PRINCIPLES OF SETTLEMENTS INTERNAL CONTROL WITH BUYERS AND CUSTOMERS FOR INCREASING THE EFFICIENCY OF FINANCIAL AND ECONOMIC ACTIVITY OF THE ENTERPRISE

Нині важливим елементом у діяльності будь-якого підприємства є здійснення контролю дебіторської заборгованості при розрахунках з покупцями та замовниками.

Метою контролю розрахунків з покупцями та замовниками є встановлення законності, достовірності і доцільності здійснення розрахунків з покупцями та замовниками підприємства і правильності їх відображення в обліку.

Завдання проведення контролю розрахунків з покупцями та замовниками: перевірка правильності визначення Аебіторської заборгованості на початок періоду, звірка дебіторської заборгованості, перевірка правильності оформлення первинних документів з розрахунків з покупцями та замовниками, перевірка правильності оформлення довіреностей при розрахунках з покупцями та замовниками, перевірка заліку заборгованості, а саме відповідність сум авансів отриманих сумам відвантаженої готової продукції покупцям, перевірка сум відвантаженої готової продукції покупцям сумам отриманої оплати, перевірка правильності класифікації дебіторської заборгованості, перевірка правильності виникнення та погашення дебіторської заборгованості, перевірка правильності нарахування та списання резерву сумнівних боргів, перевірка правильності кореспонденції рахунків 3 розрахунків 3 покупцями та замовниками, перевірка правильності визначення залишку дебіторської заборгованості на кінець періоду.

Запропонована методика контролю розрахунків з покупцями та замовниками Аля підвищення фінансової безпеки, яка на відміну від існуючих включає: анкету, загальний план контролю, програму контролю, робочі документи перевіряючого. Запропонована методика проведення перевірки надасть змогу перевіряючому охопити всі аспекти обліку розрахунків з покупцями та замовниками на підприємстві, дослідити правильність, своєчасність, законність відображення в обліку розрахунків з покупцями та замовниками, вчасно виявити порушення, провести якісний контроль та підвищити фінансову безпеку підприємства.

Currently, an important element in the activities of any enterprise is the control of accounts receivable when calculating with buyers and customers.

The purpose of controlling settlements with buyers and customers is to establish the legality, authenticity and expediency of making settlements with buyers and customers of the company and the correctness of their reflection in the account.

The task of controlling settlements with customers and clients: checking the correctness of the definition of receivables at the beginning of the period, reconciliation of receivables, checking the correctness of the execution of primary documents on settlements with buyers and customers, checking the correctness of the execution of power of attorney in calculations with buyers and customers, checking offsetting debt, and It is the correspondence of the amount of advances received by the shipments of finished goods to buyers, checking the amount shipped ready checking the correctness of the occurrence and repayment of receivables, checking the correctness of charging and debiting the reserve of doubtful 
debts, checking the correctness of the correspondence of accounts with settlements with buyers and customers, checking the correctness of determining the balance of accounts receivable at the end of the period.

The proposed method of checking settlements with buyers and customers for increasing financial security, which, in contrast to the existing, includes: a questionnaire, a general plan of control, a control program, working documents of the controller.

The proposed verification methodology will enable the inspector to cover all aspects of accounting for settlements with customers and clients at the enterprise, to investigate the correctness, timeliness, legality of the settlement in accounts of buyers and customers, to detect violations in a timely manner, to conduct qualitative control and to increase financial safety of the enterprise.

Ключові слова: внутрішній аудит, розрахунки з покупиями та замовниками, анкета, план, програма, робочі документи, ефективність.

Key words: internal audit, settlements with buyers and customers, questionnaire, plan, program, working documents, efficiency.

\section{АКТУАЛЬНІСТЬ ТЕМИ ДОСЛІДЖЕННЯ}

Нині важливим елементом у діяльності будь-якого підприємства є здійснення контролю дебіторської заборгованості при розрахунках $з$ покупцями та замовниками. При проведенні внутрішнього контролю необхідно приділити особливу увагу аналізу виникнення та термінів погашення дебіторської заборгованості, дієвому контролю за сумнівною та безнадійною заборгованістю, створенню резерву сумнівних боргів. Це допоможе у разі виникнення необхідності, вчасно у визначені законом строки звернутися до суду за захистом свої прав та законних інтересів.

\section{ПОСТАНОВКА ПРОБЛЕМИ}

Керівники багатьох великих та середніх підприємств прийшли до висновку, що чим якісніше організовано внутрішній контроль, тим ефективніші результати роботи цих підприємств. Aле, на жаль, основна проблема полягає у відсутності комплексної методики для проведення перевірки.

\section{АНАЛІЗ ОСТАННІХ ДОСЛІДЖЕНЬ ТА ПУБЛІКАЦІЙ}

Проблемними питаннями внутрішнього контролю розрахунків з покупцями та замовниками займалися такі вітчизняні та зарубіжні вчені: Бескоста Г.М., Бутинець Ф.Ф., Кулаковська М.П., Макаренко А.П., Меліхова Т.О., Піча Ю.В., Подмешальська Ю.В., Салига С.Я., Сахарцева I.І., Усач Б.Ф. та інші. Автори розглядають дане питання з різних точок зору та акцентують увагу на різних аспектах проведення контролю дебіторської заборгованості. Проте саме питання побудови дієвої методики внутрішнього контролю розрахунків з покупцями та замовниками авторами розкрито недостатньо і потребує подальшого дослідження.

\section{МЕТА ДОСЛІДЖЕННЯ}

Метою роботи є удосконалення методики внутрішнього контролю розрахунків з покупцями та замовниками для підвищення ефективності фінансово-господарської діяльності підприємства.

\section{Таблиця 1. Анкета перевірки розрахунків з покупцями} та замовниками

\begin{tabular}{|c|c|c|c|c|c|}
\hline \multirow[b]{2}{*}{ № } & \multirow[b]{2}{*}{ Зміст питання } & \multicolumn{4}{|c|}{ Варіанти відповіді } \\
\hline & & $\begin{array}{c}\text { Інформація } \\
\text { відсутня }\end{array}$ & Так & $\mathrm{Hi}$ & Примітки \\
\hline 1 & $\begin{array}{l}\text { Чи проводиться аналіз дебіторської } \\
\text { заборгованості? }\end{array}$ & & & & \\
\hline 2 & $\begin{array}{l}\text { Чи здійснюється перевірка } \\
\text { дебіторської заборгованості? }\end{array}$ & & & & \\
\hline 3 & $\begin{array}{l}\text { Чи здійснюється класифікація } \\
\text { дебіторської заборгованості? }\end{array}$ & & & & \\
\hline 4 & $\begin{array}{l}\text { Чи розраховується резерв сумнівних } \\
\text { боргів? }\end{array}$ & & & & \\
\hline 5 & $\begin{array}{l}\text { Чи здійснюється інвентаризація } \\
\text { дебіторської заборгованості? }\end{array}$ & & & & \\
\hline 6 & $\begin{array}{l}\text { Яка періодичність проведення } \\
\text { інвентаризації розрахунків } 3 \\
\text { покупцями та замовниками: }\end{array}$ & & & & \\
\hline & - раз на рік & & & & \\
\hline & - двічі на рік & & & & \\
\hline & - не проводиться? & & & & \\
\hline 7 & $\begin{array}{l}\text { Як ведеться облік розрахунків } 3 \\
\text { покупцями та замовниками: }\end{array}$ & & & & \\
\hline & - вручну & & & & \\
\hline & - автоматизовано & & & & \\
\hline & - комбіновано? & & & & \\
\hline 8 & $\begin{array}{l}\text { Хто приймає рішення про відпуск у } \\
\text { виробництво та випуск готової } \\
\text { продукції: }\end{array}$ & & & & \\
\hline & - керівник & & & & \\
\hline & - головний бухгалтер & & & & \\
\hline & - начальник виробництва & & & & \\
\hline
\end{tabular}


Таблиця 2. Загальний план проведення контролю розрахунків з покупцями та замовниками

\begin{tabular}{|c|c|c|c|c|}
\hline $\begin{array}{c}\text { Етап } \\
\text { перевірки }\end{array}$ & Процедури перевірки & $\begin{array}{c}\text { Методи } \\
\text { перевірки }\end{array}$ & $\begin{array}{c}\text { Період } \\
\text { прове- } \\
\text { дення }\end{array}$ & $\begin{array}{l}\text { Вико- } \\
\text { навці }\end{array}$ \\
\hline Підготовчий & $\begin{array}{l}\text { Знайомство з бізнесом клієнта, планування проведення } \\
\text { контролю розрахунків з покупцями та замовниками }\end{array}$ & & & \\
\hline Основний & $\begin{array}{l}\text { Перевірка правильності визначення дебіторської } \\
\text { заборгованості на початок періоду. } \\
\text { Звірка дебіторської заборгованості. } \\
\text { Перевірка правильності оформлення первинних документів } \\
\text { при розрахунках з покупцями та замовниками. } \\
\text { Перевірка правильності оформлення довіреності при } \\
\text { розрахунках з покупцями та замовниками. } \\
\text { Перевірка заліку заборгованості - відповідність сум авансів } \\
\text { отриманих сумам відвантаженої готової продукції покупцям. } \\
\text { Перевірка сум відвантаженої готової продукції покупцям } \\
\text { сумам отриманої оплати перевірка правильності класифікації } \\
\text { дебіторської заборгованості. } \\
\text { Перевірка правильності класифікації дебіторської } \\
\text { заборгованості. } \\
\text { Перевірка правильності виникнення та погашення } \\
\text { дебіторської заборгованості. } \\
\text { Перевірка правильності нарахування та списання резерву } \\
\text { сумнівних боргів. } \\
\text { Перевірка правильності кореспонденції рахунків при } \\
\text { розрахунках з покупцями та замовниками. } \\
\text { Перевірка правильності визначення залишку дебіторської } \\
\text { заборгованості на кінець періоду }\end{array}$ & $\begin{array}{l}\text { Суцільна, } \\
\text { суцільна, } \\
\text { вибіркова, } \\
\text { вибіркова, } \\
\text { вибіркова, } \\
\text { вибіркова, } \\
\text { вибіркова, } \\
\text { вибіркова, } \\
\text { вибіркова, } \\
\text { вибіркова, } \\
\text { суцільна }\end{array}$ & & \\
\hline Завершальний & Складання звіту за результатами перевірки & & & \\
\hline
\end{tabular}

\section{ВИКЛАД ОСНОВНОГО МАТЕРІАЛУ (РЕЗУЛЬТАТИ РОБОТИ)}

При проведенні перевірки спочатку встановлюється перелік дебіторів з визначенням критично допустимої величини їх заборгованості підприємству, що дає змогу сформувати загальну суму дебіторської заборгованості, яка має значний вплив на платоспроможність підприємства та розрахувати резерв сумнівних боргів. Своєчасний контроль за сумами дебіторської заборгованості надасть змогу застосовувати заходи до її погашення та своєчасної подачі позов до суду щодо стягнення сумнівної заборгованості. Одним із заходів попередження несплати дебіторської заборгованості $€$ нагадування покупцям про необхідність її сплати, нарахування фінансових санкцій за невчасну оплату, а це можливо тільки за допомогою аналізу втрат, пов'язаних з затримкою надходження грошових коштів.

При укладанні договорів та відвантаженні готової продукції покупцям потрібно здійснювати обов'язкову внутрішню перевірку документів та відомостей про покупця, щоб уникнути шахрайських дій покупця. При укладанні договорів можливо застосування особливих умов розрахунків з покупцями та замовниками. Важливе місце повинне займати надання покупцям певних преференцій при збільшенні кількості замовлень постійним покупцям, а також при $100 \%$ попередній оплаті замовлення.

Метою контролю розрахунків з покупцями та замовниками є встановлення законності, достовірності і доцільності здійснення розра- хунків з покупцями та замовниками підприємства і правильності їх відображення в обліку.

Завданнями проведення контролю розрахунків з покупцями та замовниками є: перевірка правильності визначення дебіторської заборгованості на початок періоду, звірка дебіторської заборгованості, перевірка правильності оформлення первинних документів з покупцями та замовниками, перевірка правильності оформлення довіреностей при розрахунках 3 покупцями та замовниками, перевірка заліку заборгованості, а саме відповідність сум авансів отриманих сумам відвантаженої готової продукції покупцям, перевірка сум відвантаженої готової продукції покупцям сумам отриманої оплати, перевірка правильності класифікації дебіторської заборгованості, перевірка правильності виникнення та погашення дебіторської заборгованості, перевірка правильності нарахування та списання резерву сумнівних боргів, перевірка правильності кореспонденції рахунків, перевірка правильності визначення залишку дебіторської заборгованості на кінець періоду.

Анкету перевірки розрахунків з покупцями та замовниками наведено в таблиці 1.

Одержавши в процесі попереднього планування дані про підприємство, перевіряючий приступає до розробки загального плану контролю розрахунків з покупцями та замовниками (табл. 2). План контролю є документом організаційно-методологічного характеру та складається з переліку робіт і строків їх виконання із зазначенням джерел інформації. Кон- 
Таблиця 3. Програма контролю розрахунків з покупцями та замовниками

\begin{tabular}{|c|c|c|c|c|c|c|c|}
\hline № & Мета контролю & Перелік процедур & Докази перевірки & $\begin{array}{c}\text { Код } \\
\text { робочого } \\
\text { документа }\end{array}$ & 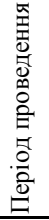 & 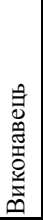 & . \\
\hline 1 & $\begin{array}{l}\text { Впевнитись у правильності } \\
\text { визначення залишку } \\
\text { дебіторської заборгованості на } \\
\text { початок періоду }\end{array}$ & $\begin{array}{l}\text { Перевірити правильність } \\
\text { визначення залишку } \\
\text { дебіторської заборгованості } \\
\text { на початок періоду }\end{array}$ & Баланс, Головна книга & Д3-1 & & & \\
\hline 2 & $\begin{array}{l}\text { Впевнитись у правильності } \\
\text { визначення дебіторської } \\
\text { заборгованості }\end{array}$ & $\begin{array}{l}\text { Провести звірку } \\
\text { дебіторської заборгованості }\end{array}$ & Акт звірки & Д3-2 & & & \\
\hline 3 & $\begin{array}{l}\text { Впевнитись у правильності } \\
\text { оформлення первинних } \\
\text { документів при розрахунках } 3 \\
\text { покупцями та замовниками }\end{array}$ & $\begin{array}{l}\text { Перевірити правильність } \\
\text { оформлення первинних } \\
\text { документів при розрахунках } \\
3 \text { покупцями та замовниками }\end{array}$ & $\begin{array}{l}\text { Договір, рахунок, накладні, } \\
\text { податкові накладні, товарно- } \\
\text { транспортні накладні, акт } \\
\text { приймання матеріалів, } \\
\text { платіжне доручення }\end{array}$ & Д3-3 & & & \\
\hline 4 & $\begin{array}{l}\text { Впевнитись у правильності } \\
\text { оформлення довіреності при } \\
\text { розрахунках з покупцями та } \\
\text { замовниками }\end{array}$ & $\begin{array}{l}\text { Перевірка правильності } \\
\text { оформлення довіреності при } \\
\text { розрахунках з покупцями та } \\
\text { замовниками }\end{array}$ & $\begin{array}{c}\text { Довіреність, Журнал } \\
\text { реєстрації довіреностей }\end{array}$ & Д3-4 & & & \\
\hline 5 & $\begin{array}{l}\text { Впевнитись у правильності } \\
\text { класифікації дебіторської } \\
\text { заборгованості }\end{array}$ & $\begin{array}{l}\text { Перевірити правильність } \\
\text { класифікації дебіторської } \\
\text { заборгованості }\end{array}$ & Рахунки обліку & Д3-5 & & & \\
\hline 6 & $\begin{array}{l}\text { Впевнитись у правильності } \\
\text { виникнення та погашення } \\
\text { дебіторської заборгованості }\end{array}$ & $\begin{array}{l}\text { Перевірити правильність } \\
\text { виникнення та погашення } \\
\text { дебіторської заборгованості }\end{array}$ & $\begin{array}{l}\text { Договір, рахунок, накладні, } \\
\text { податкові накладні, товарно- } \\
\text { транспортні накладні, акт } \\
\text { приймання матеріалів, } \\
\text { платіжне доручення }\end{array}$ & $\begin{array}{l}\text { Д3-6, } \\
\text { Д3-7, } \\
\text { Д3-8 }\end{array}$ & & & \\
\hline 7 & $\begin{array}{l}\text { Впевнитись у правильності } \\
\text { розрахунку резерву сумнівних } \\
\text { боргів }\end{array}$ & $\begin{array}{l}\text { Перевірити правильність } \\
\text { нарахування та списання } \\
\text { резерву сумнівних боргів }\end{array}$ & $\begin{array}{c}\text { Довідка бухгалтерії, } \\
\text { Відомість нарахування } \\
\text { резерву сумнівних боргів }\end{array}$ & Д3-9 & & & \\
\hline 8 & $\begin{array}{l}\text { Впевнитись у правильності } \\
\text { кореспонденції рахунків при } \\
\text { розрахунках з покупцями та } \\
\text { замовниками }\end{array}$ & $\begin{array}{l}\text { Перевірити правильність } \\
\text { кореспонденції рахунків при } \\
\text { розрахунках з покупцями та } \\
\text { замовниками }\end{array}$ & Журнал 3, Головна книга & Д3-10 & & & \\
\hline 9 & $\begin{array}{l}\text { Впевнитись у правильності } \\
\text { визначення залишку } \\
\text { дебіторської заборгованості на } \\
\text { кінець періоду }\end{array}$ & $\begin{array}{l}\text { Перевірити правильність } \\
\text { визначення залишку } \\
\text { дебіторської заборгованості } \\
\text { на кінець періоду }\end{array}$ & Баланс, Головна книга & Д3-11 & & & \\
\hline
\end{tabular}

Таблиця 4. Робочий документ перевіряючого Д3-1 - перевірка правильності визначення дебіторської заборгованості на початок періоду

\begin{tabular}{|l|c|c|c|c|c|}
\hline $\begin{array}{c}\text { Рахунок, рядок } \\
\text { Балансу }\end{array}$ & $\begin{array}{c}\text { Журнал, } \\
\text { грн }\end{array}$ & $\begin{array}{c}\text { Головна книга, } \\
\text { грн }\end{array}$ & Баланс, грн & \multicolumn{2}{|c|}{ Відхилення } \\
\cline { 5 - 6 } \\
\hline $\begin{array}{l}\text { Рax. 36-38, } \\
\text { pяд. 1125 }\end{array}$ & & & & & Головної книги від журналу, грн \\
\hline
\end{tabular}

Таблиця 5. Робочий документ перевіряючого д3-2 - Звірка дебіторської заборгованості

\begin{tabular}{l|c|c|c|c} 
Назва дебітора & За даними підприємства, грн & За даними контролю, грн & Відхилення, грн & Причина відхилення \\
\hline
\end{tabular}

Таблиця 6. Робочий документ перевіряючого д3-3 - перевірка правильності оформлення первинних документів при розрахунках з покупцями та замовниками

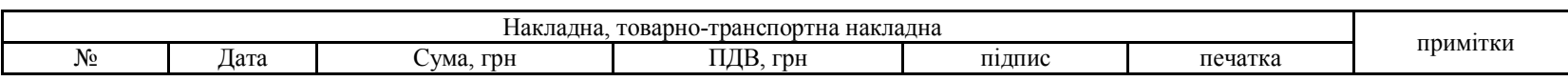

Таблиця 7. Робочий документ перевіряючого Д3-4 - перевірка правильності оформлення довіреності при розрахунках з покупцями та замовниками

\begin{tabular}{|c|c|c|c|c|c|c|}
\hline \multirow{2}{*}{$\begin{array}{c}\text { ПІБ матеріально- } \\
\text { відповідальної особи }\end{array}$} & \multicolumn{2}{|c|}{ Довіреність } & \multicolumn{2}{|c|}{ Журнал реєстрації довіреностей } & \multicolumn{2}{|c|}{ Відхилення, грн } \\
\hline & Дата видачі & Дата отримання & Дата видачі & Дата отримання & Дата видачі & Дата отримання \\
\hline
\end{tabular}

троль розрахунків з покупцями та замовниками нами рекомендується проводити в кілька етапів.
Програму контролю розрахунків з покупцями та замовниками наведено в таблиці 3. У програмі контролю розрахунків 3 покупцями 
Таблиця 8. Робочий документ перевіряючого д3-5 - перевірка правильності класифікації дебіторської заборгованості

\begin{tabular}{|l|l|l|l|}
\hline \multicolumn{1}{|c|}{ Вид дебіторської заборгованості } & За даними підприємства, грн & За даними контролю, грн & Відхилення, грн \\
\hline Розрахунки за виданими авансами & & & \\
\hline Розрахунки з підзвітними особами & & & \\
\hline Розрахунки за нарахованими доходами & & & \\
\hline Розрахунки за претензіями & & & \\
\hline Розрахунки за відшкодуванням завданих збитків & & & \\
\hline Розрахунки за позиками членам кредитних спілок & & & \\
\hline Розрахунки з іншими дебіторами & & & \\
\hline Розрахунки з державними цільовими фондами & & & \\
\hline Розрахунки за операціями з деривативами & & \\
\hline
\end{tabular}

Таблиця 9. Робочий документ перевіряючого д3-6 - перевірка заліку заборгованості відповідності сум авансів отриманих сумам відвантаженої готової продукції покупцям

\begin{tabular}{|c|c|c|c|c|c|c|}
\hline \multirow[b]{2}{*}{ ПІБ дебітора } & \multicolumn{2}{|c|}{ За даними підприємства, грн } & \multicolumn{2}{|c|}{ За даними контролю, грн } & \multicolumn{2}{|c|}{ Відхилення, грн } \\
\hline & $\begin{array}{c}\text { Отримано аванс } \\
(\text { рах 681) }\end{array}$ & $\begin{array}{c}\text { Відвантажено ГП } \\
(\text { pax 36) }\end{array}$ & $\begin{array}{c}\text { Отримано аванс } \\
(\text { рах 681) }\end{array}$ & $\begin{array}{c}\text { Відвантажено ГП } \\
(\text { рах 36) }\end{array}$ & $\begin{array}{c}\text { Отримано аванс } \\
(\text { рах 681) }\end{array}$ & $\begin{array}{c}\text { Відвантажено ГП } \\
(\operatorname{pax} 36)\end{array}$ \\
\hline
\end{tabular}

Таблиця 10. Робочий документ перевіряючого д3-7 - перевірка сум відвантаженої готової продукції покупцям сумам отриманої від них оплати

\begin{tabular}{|c|c|c|c|c|c|c|}
\hline \multirow{2}{*}{ ПІБ дебітора } & \multicolumn{2}{|c|}{ За даними підприємства, грн } & \multicolumn{2}{|c|}{ За даними контролю, грн } & \multicolumn{2}{|c|}{ Відхилення, грн } \\
\cline { 2 - 6 } & $\begin{array}{c}\text { Відванта-жено } \\
\text { ГП (рах 36) }\end{array}$ & $\begin{array}{c}\text { Отримано оплату від } \\
\text { покупців (рах 31) }\end{array}$ & $\begin{array}{c}\text { Відванта-жено ГП } \\
(\text { рах 36) }\end{array}$ & $\begin{array}{c}\text { Отримано оплату } \\
\text { від покупців } \\
(\operatorname{pax~31)~}\end{array}$ & $\begin{array}{c}\text { Відванта-жено } \\
\text { ГП (рах 36) }\end{array}$ & $\begin{array}{c}\text { Отримано оплату } \\
\text { від покупців } \\
(\operatorname{pax~31)~}\end{array}$ \\
\hline
\end{tabular}

Таблиця 11. Робочий документ перевіряючого Д3-8 - перевірка правильності виникнення та погашення дебіторської заборгованості

\begin{tabular}{|l|c|c|c|c|c|c|c|c|c|}
\hline \multirow{2}{*}{ Показники } & \multicolumn{2}{|c|}{ За даними підприємства, грн } & \multicolumn{3}{|c|}{ За даними контролю, грн } & \multicolumn{3}{|c|}{ Відхилення, грн } \\
\cline { 2 - 9 } & Поточна & Сумнівна & Безнадійна & Поточна & Сумнівна & Безнадійна & Поточна & Сумнівна & Безнадійна \\
\hline Виникнення & & & & & & & & & \\
\hline Погашення & & & & & & & & & \\
\hline Затримка & & & & & & & & & \\
\hline
\end{tabular}

Таблиця 12. Робочий документ перевіряючого д3-9 - перевірка правильності нарахування та списання резерву сумнівних боргів

\begin{tabular}{|l|c|c|c|c|c|c|c|c|c|}
\hline \multirow{2}{*}{ Показник } & \multicolumn{3}{|c|}{ За даними підприсмства, грн } & \multicolumn{3}{c|}{ За дании контролю, грн } & \multicolumn{3}{|c|}{ Відхилення, грн } \\
\cline { 2 - 9 } & $\begin{array}{c}\text { Заборго- } \\
\text { ваність }\end{array}$ & $\begin{array}{c}\text { Нараховано } \\
\text { резерв }\end{array}$ & $\begin{array}{c}\text { Списано } \\
\text { резерв }\end{array}$ & $\begin{array}{c}\text { Заборго- } \\
\text { ваність }\end{array}$ & $\begin{array}{c}\text { Нараховано } \\
\text { резерв }\end{array}$ & $\begin{array}{c}\text { Списано } \\
\text { резерв }\end{array}$ & $\begin{array}{c}\text { Заборго- } \\
\text { ваність }\end{array}$ & $\begin{array}{c}\text { Нараховано } \\
\text { резерв }\end{array}$ & $\begin{array}{c}\text { Списано } \\
\text { резерв }\end{array}$ \\
\hline Сумнівна & & & & & & & & & \\
\hline Безнадійна & & & & & & & & & \\
\hline
\end{tabular}

Таблиця 13. Робочий документ перевіряючого Д3-10 - перевірка правильності кореспонденції рахунків при розрахунках з покупцями та замовниками

\begin{tabular}{|c|c|c|c|c|c|c|c|c|c|}
\hline \multirow{2}{*}{ Зміст операції } & \multicolumn{3}{|c|}{ За даними підприємства } & \multicolumn{3}{|c|}{ За даними контролю } & \multicolumn{3}{|c|}{$\begin{array}{c}\text { Відхилення та запропоноване } \\
\text { виправлення }\end{array}$} \\
\hline & Дт & KT & Сума, грн & Дт & KT & Сума, грн & Дт & Кт & Сума, грн \\
\hline
\end{tabular}

Таблиця 14. Робочий документ перевіряючого д3-11 - перевірка правильності визначення залишку дебіторської заборгованості на кінець періоду

\begin{tabular}{|c|c|c|c|c|c|}
\hline \multirow[b]{2}{*}{$\begin{array}{c}\text { Рахунок, } \\
\text { рядок у Балансі }\end{array}$} & \multirow[b]{2}{*}{$\begin{array}{c}\text { Головна книга, } \\
\text { грн }\end{array}$} & \multirow{2}{*}{$\begin{array}{c}\text { Баланс на } \\
\text { кінець поперед- } \\
\text { нього періоду, } \\
\text { грн }\end{array}$} & \multirow[b]{2}{*}{$\begin{array}{c}\text { Баланс на } \\
\text { початок звітного } \\
\text { періоду, грн }\end{array}$} & \multicolumn{2}{|c|}{ Відхилення, грн } \\
\hline & & & & $\begin{array}{c}\text { Балансу на початок } \\
\text { звітного періоду від } \\
\text { Головної книги } \\
\end{array}$ & $\begin{array}{c}\text { Балансу на початок звітного } \\
\text { періоду від балансу на кінець } \\
\text { попереднього періоду, грн }\end{array}$ \\
\hline $\begin{array}{l}\text { Рах. 36-38, } \\
\text { ряд. } 1125\end{array}$ & & & & & \\
\hline
\end{tabular}

та замовниками відображено основні процедури для вирішення основних завдань перевірки.

Аля вирішення поставлених завдань контролю розрахунків з покупцями та замовника- ми пропонуємо робочі документи перевіряючого (табл. 4-14), які на нашу думку стануть обгрунтованими доказами якісного проведення контролю розрахунків з покупцями та замовниками. 


\section{ВИсновки}

Запропонована методика контролю розрахунків з покупцями та замовниками, яка на відміну від існуючих включає: анкету, загальний план контролю, програму контролю, робочі документи перевіряючого. Запропонована методика проведення перевірки надасть змогу перевіряючому охопити всі аспекти обліку розрахунків з покупцями та замовниками на підприємстві, дослідити правильність, своєчасність, законність відображення в обліку розрахунків з покупцями та замовниками, вчасно виявити порушення, провести якісний контроль та підвищити ефективність фінансово-господарської діяльності підприємства.

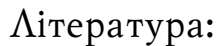

1. Макаренко А.П. Аудит: навч.-метод. посібник / А. П. Макаренко, Т.О. Меліхова, Г.М.Бескоста. - Запоріжжя: ЗАIA, 2016. - 184 с.

2. Макаренко А.П. Організація і методика аудит: навч.-метод. посібник / А.П. Макаренко, Т.О. Меліхова, Г.М. Бескоста. - Запоріжжя: 3АIA, 2015. — 190 с.

3. Макаренко А.П. Теоретико-методичні основи та практичні підходи до вдосконалення аудиту лізингових операцій / А.П. Макаренко, Т.О. Меліхова // Економічний вісник Запорізької державної. - 2016. - № 6. - С. 164-171.

4. Макаренко А.П. Бухгалтерський облік: навч.-метод. посібник / А.П. Макаренко, Т.О. Меліхова, Ю.В. Подмешальська, Н.С. Чакалова. - Запоріжжя: 3АIA, 2018. - 602 с.

5. Макаренко А.П. Інформаційна база заповнення спрощеної звітності - інструмент управління та фінансової безпеки / А.П. Макаренко, Т.О. Меліхова, Н.С. Чакалова // Часопис економічних реформ. - 2014. - № 1 . C. 26-32.

6. Макаренко А.П. Удосконалення облікових регістрів 3 метою своєчасного управління підприємством та контролю за його фінансовою безпекою/ А.П. Макаренко, Т.О. Меліхова, Н.С. Чакалова // Економічний вісник університету. - 2014. - Вип. 22 (1). - С. 85-95.

7. Макаренко А.П. Удосконалення аудиту короткострокової дебіторської заборгованості/ А.П. Макаренко, А.В. Ахмєдова // Агросвіт, 2018. — № 2. - C. 45-51.

8. Макаренко А.П. Аержавний фінансовий контроль: навч. посібник для внз: [гриф 3АIA] / А.П. Макаренко, І. Я. Максименко, Т.О. Меліхова, О.П. Зоря. - Запоріжжя: ЗАІА, 2017. $280 \mathrm{c}$.

9. Макаренко А.П. Соціальне страхування: сутність, значення та обліковий аспект: навч. посібник: [гриф 3АIA] / А.П. Макаренко, О.П. Зоря, Т.О. Меліхова, І.Я. Максименко. Запоріжжя: 3АIA, 2017. - 200 с.

10. Макаренко А.П. Оподаткування в системі обліку: навч.-метод. посібник / А.П. Макаренко, Т.О. Меліхова, О.В. Гамова; ЗАІА. Запоріжжя: 3АIA, 2015. - 147 с.

11. Макаренко А.П. Податкове планування та мінімізація податкових ризиків: навч. посібник: [рек. вченою радою 3АIA]/ А.П. Макаренко, Т.О. Меліхова, Н.С. Чакалова; 3АIA. Запоріжжя: 3АIA, 2017. - 260 с.

12. Меліхова Т.О. Розробка програми аудиту касових операцій для підвищення ефективності діяльності підприємства / Т.О. Меліхова, Т.В. Манойло // Регіональна бізнес-економіка та управління. - 2013. - № 2. - C. 97-106.

13. Меліхова Т.О. Удосконалення документального забезпечення аудиту розрахунків 3 підзвітними особами з метою якісного проведення перевірки / Т.О. Меліхова, К.О. Новосьолова // Проблеми і перспективи розвитку банківської системи України. - 2012. - Вип. 36. - С. 108-116.

14. Меліхова Т.О. Розробка програми аудиту ефективності використання основних засобів на підприємстві / Т.О. Меліхова, О. Буркова // Економічний аналіз. - 2012. - Вип. 11. Ч. 4. - C. $257-264$.

15. Меліхова Т.О. Економічна безпека підприємства: формування, контроль, ефективність: монографія Херсон, Видавничий дім "Гельветика". - 2018. - 632 с.

16. Меліхова Т.О. Удосконалення документування обліку розрахунків з покупцями та замовниками з метою зміцнення інформаційної безпеки підприємства / Т.О. Меліхова, Ф.О. Гавриленко // Інвестиції: практика та досвід, 2018. - № 2. - C. 24-32

17. Меліхова Т.О. Розробка програми аудиту виробничих запасів для підвищення фінансової безпеки підприємства / Т.О. Меліхова, Н.С. Ніколаєнко // Економіка та держава. 2017. — № 1. - C. 51-55.

18. Меліхова Т.О. Розробка програми аудиту податку на прибуток для підвищення фінансової безпеки підприємства / Т.О. Меліхова, М.М. Бикова // Агросвіт. - 2017. — № 1-2. C. $19-25$.

19. Меліхова Т.О. Розробка програми аудиту податку на додану вартість для підвищення фінансової безпеки підприємства / Т.О. Меліхова, М.Ю. Бойко // Інвестиції: практика та досвід. - 2017. - № 1. - С. 34-39.

20. Меліхова Т.О. Розробка програми аудиту екологічного податку для підвищення фінан- 
сової безпеки підприємства / Т.О. Меліхова, О.С. Зуб// Ефективна економіка. - 2016. - № 12 [Електронний ресурс]. - Режим доступу: http://www.economy.nayka.com.ua/?n=12\&$\mathrm{y}=2016$

21. Меліхова Т.О. Розробка програми аудиту витрат на виробництво для підвищення фінансової безпеки підприємства / Т.О. Меліхова, В.В. Височина // Економіка та держава. -2018 . - № 1. - С. 69-75.

22. Меліхова Т.О. Внутрішній контроль виробничих запасів для своєчасного виявлення загроз в системі управління фінансової безпеки підприємства / Т.О. Меліхова, І.О. Федоров. // Агросвіт. - 2018. - № 2. - C. 63-70.

23. Меліхова Т.О. Аналіз впливу податкового навантаження на рівень податкової безпеки підприємства / Т.О. Меліхова, О.В. Троян // Інвестиції: практика та досвід. - 2017. № $20 .-$ C. $33-37$.

24. Меліхова Т.О. Удосконалення методики внутрішнього аудиту розрахунків із покупцями з метою запобігання порушень під час тендерних закупівель. / Т.О. Меліхова, Н.С. Чакалова, А.С. Кулєк // Агросвіт. - 2019. - № 4. C. 32-41. DOI: 10.32702/2306-6792.2019.4.32

25. Подмешальська Ю.В. Бухгалтерський облік: навч.-метод. посібник/ Ю.В. Подмешальська, Т.О. Меліхова, Н.С. Чакалова. - Запоріжжя: 3АIA, 2017. - 400 с.

26. Салига С.Я. Аудит податків суб'єктів господарювання: монографія / С.Я. Салига, T.О. Меліхова. - Запоріжжя:КПУ, 2011. - 224 с.

27. Теорія і практика документування в облікуі аудиті: навч.-метод. посібник Ч. 2/ А. П. Макаренко, О.М. Панченко, А.В. Таратута, Т.О. Меліхова, А.А. Птіцина; ЗАІА. - Запоріжжя: 3AIA, 2011. - $127 \mathrm{c}$.

28. Maksymenko I. Accounting and analytical procurement of state financial control and directions of its implementation in Ukraine / I. Maksymenko, T. Melikhova // Baltic Journal of Economic Studies, Volume 3 Number 5. Riga: Publishing House "Baltija Publishing", 2017, P. 268-275.

\section{References:}

1. Makarenko, A.P. Melikhova, T.O. and Beskosta, H.M. (2016), Audyt [Audit], ZDIA, Zaporizhzhya, Ukraine.

2. Makarenko, A.P. Melikhova, T.O. and Beskosta, H.M. (2015), Orhanizatsiya i metodyka audyt [Organization and method of audit], ZDIA, Zaporizhzhya, Ukraine.

3. Makarenko, A.P. and Melikhova, T.O. (2016) "Theoretical and methodological foundations and practical approaches to improving the audit of leasing operations", Ekonomichnyy visnyk Zaporizkoyi derzhavnoyi inzhenernoyi akademiyi, vol. 6, pp. 164-171.

4. Makarenko, A.P. Melikhova, T.O. Podmeshalska, Y.V. and Chakalova, N.S. (2018), Bukhhalterskyy oblik: navch.-metod. posibnyk [Accounting: teaching method. manual], ZDIA, Zaporizhzhya, Ukraine.

5. Makarenko, A.P. Melikhova, T.A. and Chakalova, N.S. (2014), "Information base for filling in simplified reporting - a tool for management and financial security", Chasopys ekonomichnykh reform, vol. 1, pp. 26-32.

6. Makarenko, A.P. Melikhova, T.A. and Chakalova, N.S. (2014), "Improving accounting records in order to manage the enterprise in a timely manner and monitor its financial security", Ekonomichnyj visnyk universytetu, vol. 22 (1), pp. $85-95$.

7. Makarenko, A.P. and Akhmyedova, D.V. (2018) "Improving the audit of short-term receivables", Ahrosvit, vol. 2, pp. 45-51.

8. Makarenko, A.P. Maksymenko, I. Ya. Melikhova, T. O. and Zorya, O.P. (2017), Derzhavnyy finansovyy kontrol, [State financial control], ZDIA, Zaporizhzhya, Ukraine.

9. Makarenko, A.P. Zorya, O.P. Melikhova, T.O. and Maksymenko, I.YA. (2017), Sotsialne strakhuvannya: sutnist, znachennya ta oblikovyy aspekt, [Social insurance: essence, value and accounting aspect], ZDIA, Zaporizhzhya, Ukraine.

10. Makarenko, A.P. Melikhova, T.O. and Hamova, O.V. (2015) Opodatkuvannya v systemi obliku : navch.-metod. posibnyk, [Taxation in the accounting system: teaching method. manual], ZDIA, Zaporizhzhya, Ukraine.

11. Makarenko, A.P. Melikhova, T.O. and Chakalova, N.S. (2017) Podatkove planuvannya ta minimizatsiya podatkovykh ryzykiv: navch. posibnyk, [Tax planning and minimization of tax risks: teaching. manual], ZDIA, Zaporizhzhya, Ukraine.

12. Melikhova, T.O. and Manojlo, T.V. (2013), "Develop a program audit of cash transactions to improve the efficiency of enterprise activity", Rehional'na biznes-ekonomika ta upravlinnia, vol. 2, pp. 97-106.

13. Melikhova, T.O. and Novos'olova, K.O. (2012), "Improvements documentary providing audit settlements with accountable accountable persons for the purpose of quality inspection", Problemy i perspektyvy rozvytku bankivs'koi systemy Ukrainy. vol. 36, pp. 108-116.

14. Melikhova, T.O. and Burkova, O. (2012), "Develop a program effectiveness audit of the use of fixed assets in the enterprise", Ekonomichnyj analiz, vol. 11, no. 4, pp. 257-264. 
15. Melikhova, T.O. (2018), Ekonomichna bezpeka pidpryyemstva: formyrovanye, kontrol, efektyvnist [Economical bezpeka p_dpriemstva: formavannya, control, effektivn_st], Kherson, Ukraine.

16. Melikhova, T.O. and Havrylenko, F.O. (2018), "Accompanied documenting of the region of rozrakhunkiv with purchases that the deputies of the merit of information about the security", Investytsiyi: praktyka ta dosvid, vol. 2, pp. 2432.

17. Melikhova, T.O. and Nikolayenko, N.S. (2017), "Development of an inventory audit program to increase financial security of the enterprise", Ekonomika ta derzhava, vol. 1, pp. $51-55$.

18. Melikhova, T.O. and Bykova, M.M. (2017), "Development of a profit tax audit program to increase the financial safety of the enterprise", Ahrosvit, vol. 1-2, pp. 19-25.

19. Melikhova, T.O. and Boyko, M.Yu. (2017), "Development of a program for the audit of value added tax to increase the financial safety of the enterprise", Investytsiyi: praktyka ta dosvid, vol. 1 , pp. 34-39.

20. Melikhova, T.O. and Zub, O.S. (2016), "Development of Environmental Tax Audit Program for Increasing Financial Safety of an Enterprise", Efektyvna ekonomika, vol.12, available at: http://www.economy.nayka.com.ua/ $? \mathrm{n}=12 \& \mathrm{y}=2016$ (Accessed 10 April 2019).

21. Melikhova, T.O. and Vysochyna, V.V. (2018), "Development of a program for auditing production costs to improve the financial safety of the enterprise", Ekonomika ta derzhava, vol. 1, pp. 69-75.

22. Melikhova, T.O. and Fedorov, I.O. (2018), "Internal control of inventory for timely detection of threats in the system of financial security management of the enterprise", Ahrosvit, vol. 2, pp. 63-70.

23. Melikhova, T.O. and Troyan, O.V. (2017), "Analysis of the impact of the tax burden on the level of tax security of the enterprise", Investytsiyi: praktyka ta dosvid, vol. 20, pp. 33-37.

24. Melikhova, T., Chakalova, N. and Kuliek, A. (2019), "Improving the methodology of internal audit of settlements with customers in order to prevent breaches of tender procurement", Agrosvit, vol. 4, pp. 32-41. DOI: 10.32702/23066792.2019.4.32

25. Podmeshalska, Y.U. Melikhova, T.O. and Chakalova, N.S. (2017), Bukhhalterskyy oblik: navch.-metod. posibnyk [Accounting: teaching method. manual], ZDIA, Zaporizhzhya, Ukraine.
26. Salyha, S.YA. and Melikhova, T.O. (2011), Audyt podatkiv sub'iektiv hospodariuvannia [Audit of Taxes of Business Entities], KPU. Zaporizhzhya, Ukraine.

27. Makarenko, A.P. Panchenko, O.M., Taratuta, L.V. and Melikhova, T.O. (2011), Teoriya i praktyka dokumentuvannya v obliku i audyti, [The theory and practice of documenting in accounting and audit], ZDIA, Zaporizhzhya, Ukraine.

28. Maksymenko, I. and Melikhova, T. (2017), "Accounting and analytical procurement of state financial control and directions of its implementation in Ukraine", Baltic Journal of Economic Studies, Vol. 3, No. 5, pp. 268-275.

Стаття надійшла до редакиії 17.04.2019 p.

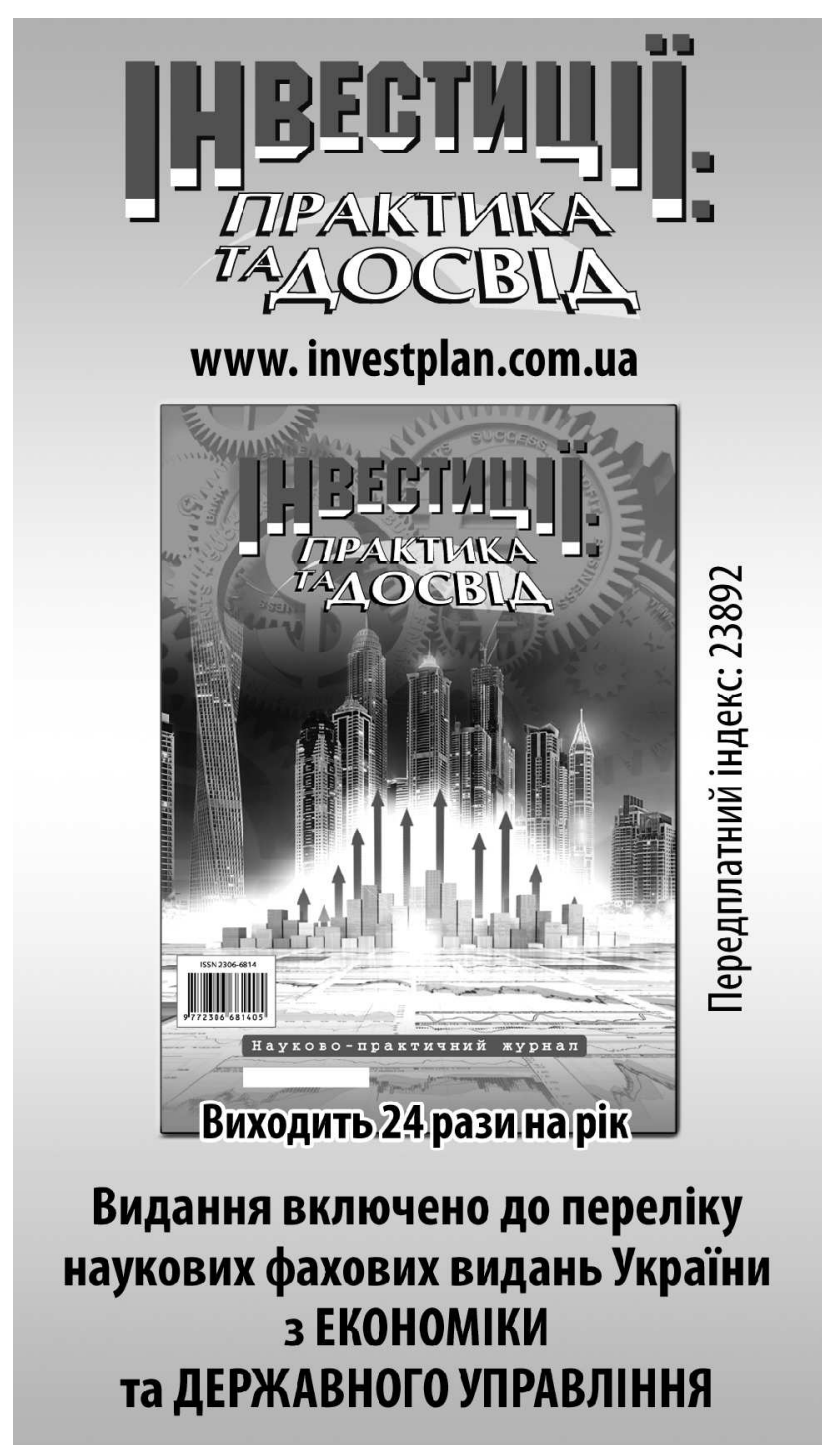


O. $\Lambda$. Руда,

к. е. н., Аоцент кафедри фінансів, банківської справи та страхування,

Вінницький національний аграрний університет, м. Вінниця

ORCID ID 0000-0002-3266-7470

DOI: $10.32702 / 2306-6792.2019 .9 .25$

\title{
СУЧАСНI ТЕНАЕНЦIÏ НА РИНКУ БАНКІВСЬКИХ ПОСАУГ В УКРАЇНI ТА ÏХ ВПЛИВ НА ФІНАНСОВУ АІЯАЬНІСТЬ БАНКІВСЬКОЇ СИСТЕМИ
}

\author{
O. Ruda, \\ Candidate of economic sciences, associate professor of department of finances, banking and insurance, \\ Vinnytsia national agrarian University, Vinnytsya
}

\section{CONTEMPORARY TRENDS IN THE BANKING SERVICES MARKET IN UKRAINE AND THEIR IMPACT ON THE FINANCIAL ACTIVITY OF THE BANKING SYSTEM}

У статті розглянуто значення банківської системи та ефективність банківської діяльності. Наведено функції які виконує банківська система. Надійна банківська система є важдивою умовою забезпечення фінансової стабільності Аержави, сталого економічного розвитку та загального добробуту, оскільки вона забезпечує рух фінансових ресурсів, без яких функціонування ринкового господарства неможливе. Виступаючи посереАниками у перерозподілі капіталів шляхом трансформації тимчасово вільних коштів у інвестиції, банки істотно підвищують загальну ефективність виробництва. Фінанси банківських установ повинні сприяти мобілізації достатнього обсягу фінансових ресурсів, отриманню доходів, зАійсненню обгрунтованих витрат, що є необхідною умовою стабільної діяльності банку.

Аналізуючи різні підходи до поняття "банківська система", ми навели чотири їх групи. Проаналізували динаміку зміни кількості банків України за 2016-2018 рр. та динаміку активів банківської системи Україні за 2015-2017 рр.

Зважаючи на проведений аналіз нами було виявлено необхідність підвищення рівня надійності, фінансової стійкості банків на внутрішньому й міжнародних ринках, тому було запропоновано відповідні заходи Аля покращення ситуації.

In this article the significance of the banking system and the efficiency of banking activity are considered. These functions are performed by the banking system. A reliable banking system is an important condition for ensuring the country's financial stability, sustainable economic development and welfare as it provides the flow of financial resources without which the functioning of a market economy is impossible. Acting as intermediaries in the redistribution of capital through the transformation of temporarily free funds into investments, banks significantly increase the overall efficiency of production. The finances of banking institutions should facilitate the mobilization of sufficient amount of financial resources, income, and reasonable expenses, which is a prerequisite for the stable operation of the bank.

Analyzing different approaches to the concept of "banking system", we set four groups. Analyzed the dynamics of changes in the number of Ukrainian banks for 2016-2018 and the dynamics of assets of the banking system of Ukraine for 2015-2017.

The current conditions for the activities of financial intermediaries in the process of economic development need to be allocated in the financial structure of such separate units as finances of banking institutions. Banking institutions play a leading role in providing the national economy with financial resources as key institutions in the financial and economic system of the country. Their role is not limited to managing only the quantitative parameters of financial resources, although they provide a concentration of significant disparate means. The main advantage of the banks is their unique ability to transform the usual funds held in the accounts of legal entities and individuals, the budget and trust funds, and credit and investment resources directed towards the development of the economy and, first of all, its real sector. As a financial institution, a modern banking institution serves as a commercial structure whose main purpose is profit making, and therefore the main tasks of its financial activity are the growth of financial potential and ensuring its effective use. 
Taking into account the analysis conducted, we have identified the need to increase the level of reliability, financial stability of banks in the domestic and international markets, therefore, appropriate measures were proposed to improve the situation.

Ключові слова: банківська діяльність, банк, банківська система, банківська послуга, фінансова стійкість, ліквідність активів, фінансові ресурси, посередники.

Key words: banking, bank, banking system, banking service, financial stability, asset liquidity, financial resources, intermediaries.

\section{ПОСТАНОВКА ПРОБЛЕМИ У ЗАГАЛЬНОМУ ВИГЛЯДІ ТА ІІЇ ЗВ'ЯЗОК ІЗ ВАЖЛИВИМИ НАУКОВИМИ ЧИ ПРАКТИЧНИМИ ЗАВДАННЯМИ}

Надійна банківська система є важливою умовою забезпечення фінансової стабільності держави, сталого економічного розвитку та загального добробуту, оскільки вона забезпечує рух фінансових ресурсів, без яких функціонування ринкового господарства неможливе. Виступаючи посередниками у перерозподілі капіталів шляхом трансформації тимчасово вільних коштів у інвестиції, банки істотно підвищують загальну ефективність виробництва. Фінанси банківських установ повинні сприяти мобілізації достатнього обсягу фінансових ресурсів, отриманню доходів, здійсненню обгрунтованих витрат, що $є$ необхідною умовою стабільної діяльності банку.

\section{АНАЛІЗ ОСТАННІХ ДОСЛІДЖЕНЬ І ПУБЛІКАЦІЙ}

Фінансові аспекти розвитку банківської діяльності знайшли своє відображення у працях як зарубіжних вчених та практиків банківської справи, зокрема західних - Е. Аолана, Аж. Кейнса, I. Фішера, М. Фрідмана, Б. Бєрмана, Аж. Сінкі, П. Роуза; російських - $\Lambda$. Батракової, Н. Куніциної, І. Ааріонової, Ю. Масленчикова, так і вітчизняних науковців М. Алексеєнко, 3. Васильченко, А. Вожжова, А. Герасимовича, О. Азюблюка, В. Міщенка, А. Мороза, А. Пересади, $\Lambda$. Примостки, Н. Шелудько.

\section{META CTATTI}

Метою статті є дослідження теоретичних, науково-методичних підходів та розробка практичних рекомендацій щодо удосконалення отримання фінансових результатів діяльності банківських установ.

\section{ВИКЛАД ОСНОВНОГО МАТЕРІАЛУ ДОСЛІДЖЕННЯ}

Ефективне управління фінансами всіх суб'єктів господарювання $є$ необхідною умо- вою забезпечення економічного благополуччя та економічного зростання національної економіки. В умовах функціонування фінансової моделі ринкової економіки, яка є відкритою, зрозумілою і точно характеризує фінансові реалії у суспільстві, структура фінансової системи є динамічною і не може розглядатися у статистичному вигляді. Важливим інструментом регулювання суспільно-економічного розвитку у ринковій економіці є фінансова політика, а основними провідниками їі реалізації $€$ банки.

Банки та інші кредитні організації діють у певному секторі ринку - в системі грошовокредитних і фінансових відносин. Цим визначається предмет їхньої діяльності: гроші, валютні цінності, інші фінансові інструменти. Банківська діяльність має безліч аспектів [1, c. 51].

Також слід розрізняти основну та допоміжну банківську діяльність. Основна банківська діяльність - це така діяльність кредитної організації, яка включає банківські операції та угоди. Аопоміжна банківська діяльність спрямована на забезпечення сприятливих і безпечних умов здійснення основної банківської діяльності. Ця діяльність побічно пов'язана 3 результатами основної банківської діяльності. Наприклад, до допоміжної банківської діяльності відносяться інформатизація, охорона, система безпеки та інші аналогічні види діяльності різних підрозділів кредитної організації.

Банківська діяльність як підприємницька діяльність, на думку О.П. Орлюка, має певну специфіку й певні, притаманні лише їй, особливі риси:

- отримання прибутку від обігу (за наявності ризиків) не тільки власних, а й залучених коштів;

- отримання прибутку від обігу фінансових інструментів, що $€$ одночасно умовою існування держави й забезпечення її суверенітету;

- наявність у силу перших двох обставин регламентованого й міцного державного регулювання цього виду підприємницької діяль- 


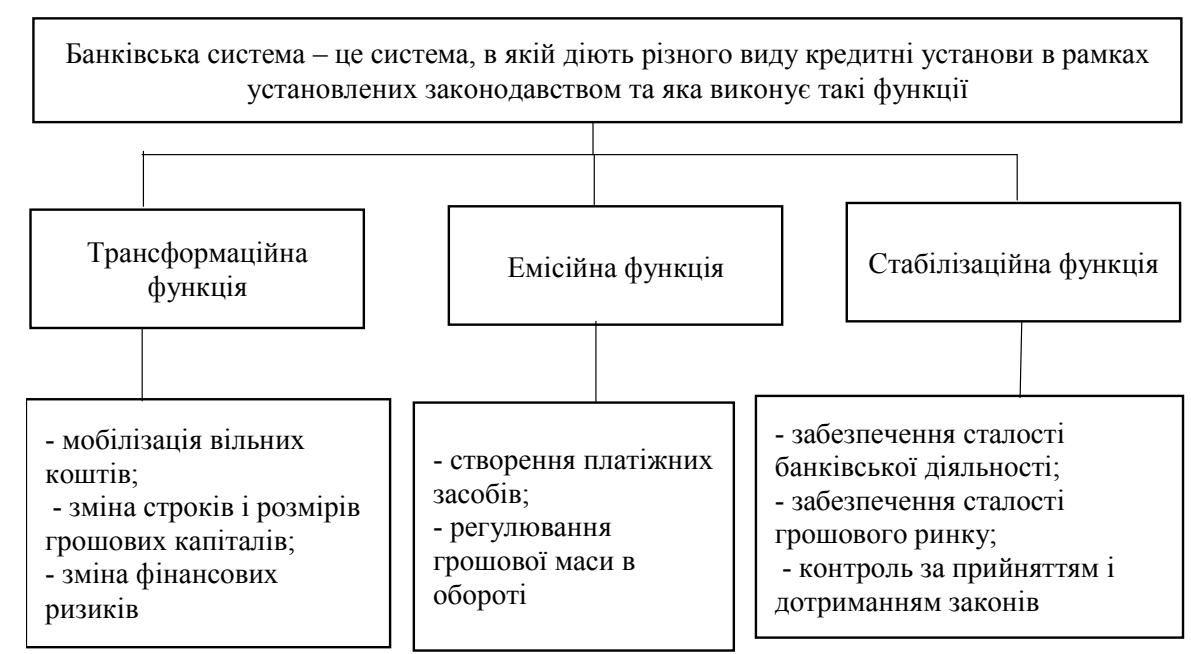

Рис. 1. Функції банківської системи

Ажерело: [1, с. 52].

ності, що забезпечує, в першу чергу, публічні інтереси, а потім уже приватні [8, с. 156].

3 поняття "банківської діяльності" випливає поняття "банківська система". В.С. Стельмах визначає, що "банківська система - це складний комплекс, який функціонує і розвивається відповідно до цілого ряду законодавчих і нормативних документів. Основним елементом цієї системи є комерційний банк - кредитно-фінансова установа, яка залучає і накопичує вільні грошові кошти підприємств, організацій, населення, а також здійснює випуск цінних паперів, кредитування народного господарства і населення на умовах платності, зворотності і строковості. Стан і рівень розвитку банків досить серйозно впливає на розвиток всієї суспільно-економічної формації". Тому, аналізуючи діяльність банківської системи, можна зрозуміти ситуацію в державі, а також зробити правильні висновки про роль Національного банку України у виконанні своєї головної функції - забезпечення стабільності національної грошової одиниці.

Аналізуючи різні підходи до поняття "банківська система", вважаємо, що їх можна об'єАнати в такі чотири групи:

- банківська система розглядається як сукупність банків держави;

- банківська система розглядається як сукупність банків, банківської інфраструктури;

- банківська система включає в себе кредитну систему;

- банківська система розглядається через систему комерційних банків [2, с. 114].

Отже, сьогодні російські вчені-економісти під банківською системою розуміють історично сформовану та законодавчо закріплену систему організації банківської справи в конк- ретній державі. У структуру сучасної банківської системи дані автори включають центральний банк, кредитні організації та філії і представництва іноземних банків. Кредитні організації розглядаються як сукупність банків та небанківських кредитних організацій.

3'ясувавши генезис поняття "банківської системи" та особливості функціонування банківської системи, перейдемо до розгляду їі структурних елементів.

Самостійність банківської системи проявляється у специфічних функціях. Функції, як структурний елемент банківської системи, відображені на рисунку 1.

Таким чином, у ході проведених досліджень можна визначити банківську діяльність як сукупність діючих спеціальних суб'єктів і операцій, які здійснюються банками згідно з переліком, встановленим законом, як учасниками єАиної банківської системи з приводу грошей, цінних паперів та валютних цінностей як засобів платежу, заощадження й товару.

Сучасний етап розвитку України характеризується гострою необхідністю створення цілісної програми соціально-економічного розвитку суспільства, а також забезпечення необхідних умов реальних перетворень фінансової, кредитної та грошової систем, адаптації їх до специфіки ринкових відносин. При цьому у сфері фінансового забезпечення економічної реформи подальшого вдосконалення потребує і банківська діяльність.

Ринок банківських послуг є однією із важливих та невід'ємних складових сучасної ринкової економіки. Тому на сьогодні зростає інтерес до різних аспектів діяльності банків та методів управління ними. Банки поступово перетворилися на основні посередники у перероз- 


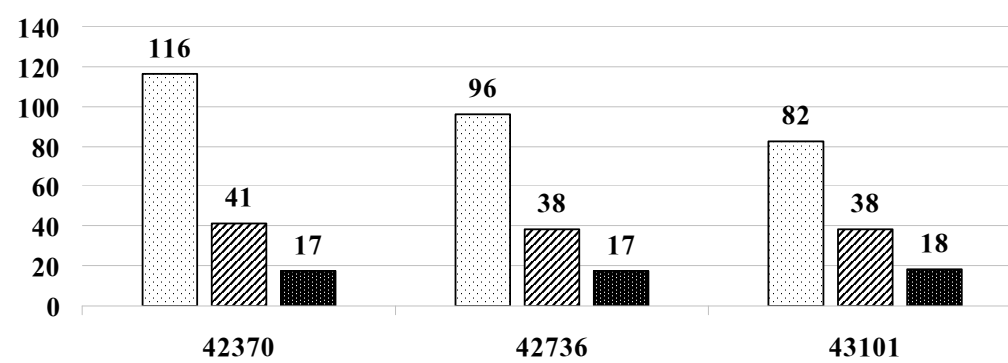

$\square$ Кількість банків, що мають ліцензію НБУ на здійснення банківських операцій

Кількість банків з іноземним капіталом

国 Кількість банків 3 100\% іноземним капіталом

Рис. 2. Динаміка зміни кількості банків України 3a 2016 - 2018 pp.

Ажерело: [6].

Таблиця 1. Динаміка активів банківської системи Україні, млрд грн

\begin{tabular}{|l|l|l|l|l|}
\hline \multirow{2}{*}{$№$} & \multicolumn{1}{|c|}{ Показник } & \multicolumn{3}{|c|}{ Станом на } \\
\cline { 3 - 5 } & & \multicolumn{1}{|c|}{$01.01 .2015 \mathrm{p}}$. & \multicolumn{1}{|c|}{$01.2016 \mathrm{p}}$. & $01.01 .2017 \mathrm{p.}$ \\
\hline 1 & Чисті активи & 1316,85 & 1254,39 & 1256,30 \\
\hline 2 & Кредитний портфель & 1006,36 & 965,09 & 1005,92 \\
\hline 3 & Вкладення в цінні папери & 168,93 & 198,84 & 332,27 \\
\hline 4 & Високоліквідні активи & 155,64 & 191,26 & 199,50 \\
\hline 5 & $\begin{array}{l}\text { Офіційний валютний курс } \\
\text { UАН/USD, грн }\end{array}$ & 15,77 & 24,00 & 27,19 \\
\hline 6 & $\begin{array}{l}\text { Середня відсоткова ставка за } \\
\text { кредитами в національній } \\
\text { валюті, \% }\end{array}$ & 18,80 & 21,47 & 17,70 \\
\hline 7 & $\begin{array}{l}\text { Середня відсоткова ставка за } \\
\text { кредитами в іноземній } \\
\text { валюті, \% }\end{array}$ & 8,30 & 6,88 & 8,20 \\
\hline
\end{tabular}

Ажерело: [6].

поділі капіталів, у забезпеченні безперервності процесу економічного відтворення.

Банківські послуги активно впливають на розвиток економіки України як на макро-, так і на мікрорівні. По-перше, банківська послуга $є$ одним із дійових факторів інтенсифікації відтворюваного процесу в цілому і такої його складової, як обмін, зокрема. По-друге, банківські послуги відіграють значну роль у задоволенні потреб населення, підвищенні його життєвого рівня шляхом надання споживчих кредитів і впливу на розвиток малого бізнесу.

Зміст категорії "банківська послуга" можна розглядати через призму поняття "фінансова послуга". Законодавство України визначає фінансову послугу як "операції з фінансовими активами, що здійснюються в інтресах третіх осіб за власний рахунок чи за рахунок цих осіб, а у випадках, передбачених законодавством, $\mathrm{i}$ за рахунок залучених від інших осіб фінансових активів, з метою отримання прибутку або збереження реальної вартості фінансових активів". Отже, поняття "банківська послуга" можна трактувати порізному, залежно від того, який саме економічний сенс чи ознака покладена в його основу [3, с. 447].
Банківські послуги на фінансовому ринку відображають динаміку ділової активності учасників таких угод - банків та клієнтів. Відновлення кредитування та стимулювання попиту позичальників на кредитні продукти є важливими питаннями стабілізації банківської, кредитної та економічної системи країни.

Станом на 01 січня 2017 р. ліцензію Національного банку України мали 96 банківських установ (у т.ч. 38 банків з іноземним капіталом). 3 початку 2016 р. кількість функціонуючих банківських установ скоротилася на 21. Починаючи 3 01.06.2016 р. Правлінням Національного банку України було прийнято декілька рішень про надання згоди на самоліквідацію банківських установ.

Першими випадками такої самоліквідації стали ПАТ "Фінанс Банк" та ПАТ "Інвестиційно-Трастовий Банк" [5]. Аетальна інформація про динаміку зміни у банківській системі України протягом 2016 р. відображена на рисунку 2.

Протягом 2015-2017 рр. спостерігається тенденція до зменшення кількість банківських установ як $з$ частковим, так із іноземним капіталом. Починаючи з 2015 р., прийнято рішення щодо ліквідації комерційних банків, що зумовило скорочення їх кількості на $40 \%$.

Однією з вагомих причин визнання банків неплатоспроможними, крім порушення законодавства, що регулює питання запобігання та протидії легалізації (відмиванню) доходів, одержаних злочинним шляхом, $є$ недостатній рівень їх капіталізації та неспроможність акціонерів забезпечити належний рівень фінансової підтримки.

Протягом 2016 р. у структурі власності банківської системи України відбувались значні перегрупування. Внаслідок переходу системного ПАТ КБ "ПриватБанк" у стовідсоткову власність держави частка державних банків в структурі активів банківської системи значно зросла протягом IV кварталу 2016 р. та станом на 01.01.2017 р. відповідала 52\%. Частка банків 3 приватним українським капіталом складала близько $13 \%$, банків іноземних банківських груп - $35 \%$. Зауважимо, що в подальшому можливе скорочення частки банків іноземних 
банківських груп внаслідок виходу 1400 банківських установ з російським капіталом 3 українського ринку. 3а підсумками 2016 р. чисті активи банківської системи України збільшились несуттєво, їх обсяг станом на 01.01.2017 р. відповідав 1256,30 млрд грн проти 1254,39 млрд грн на початок року (табл. 1).

Аані таблиці 1 показують значні зміни активів банківської системи України у 2016 р. порівняно з 2015 р., а саме стрімко підвищився офіційний курс валюти з 15,77 грн до 24,00 грн, тобто на 8,23 грн, що $є$ негативним явищем. Отже, аналіз сучасного ста-

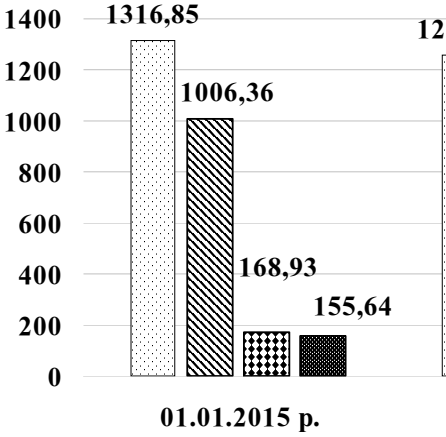

01.01.2015 p.

$\checkmark$ Чисті активи

由 Вкладення в цінні папери
1256,3

254,39

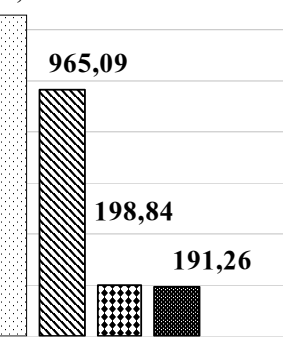

01.01.2016 p.

$\$$ Кредитний портфель

Високоліквідні активи

Рис. 3. Динаміка активів банківської системи Україні

Ажерело: [6]. за 2015-2017 рр., млрд грн

ну банківського сектору національної економіки дає можливість виявити декілька проблем у банківській сфері: політична та фінансова нестабільність у країні; низька якість банківських активів; зниження ліквідності банківських активів; недосконала нормативно-правова база в державі; високий ступінь вразливості банківської системи до валютно-курсової політики в країні, що проводиться Національним банком України.

Протягом 2016 р. обсяг клієнтського кредитного портфелю скоротився на $0,4 \%$ (3,85 млрд грн) та станом на 01.01.2017 р. відповідав 1005,92 млрд грн (рис. 3). Серед причин, що призвели до погіршення ситуації у динаміці активів банківської системи можна зазначити нестабільну політичну та економічну ситуацію в країні, низьку платоспроможність вітчизняних позичальників, неврегульованість процедури банкрутства та процедури реєстрації, високий кредитний ризик, що у свою чергу, вимагає формування значних резервів.

Високий рівень доларизації економіки країни призводить до інфляції. Водночас за умови фінансової стабілізації та суворої монетарної політики можна значно знизити рівень доларизації в Україні, проте постійно його утримувати неможливо, адже юридичні та фізичні особи купують та зберігають тверду іноземну валюту на депозитних рахунках у комерційних банках.

Аинаміка клієнтського кредитного портфелю в розрізі позичальників та рівень доларизації кредитів протягом 2016 р.

Рівень доларизації кредитів станом на 01.01 .2017 р. зменшився з $58 \%$ до $52 \%$, тобто на $6 \%$.

Курсові різниці виступають вагомим чинником коливання сукупного обсягу кредитного портфеля протягом року, оскільки близько половини виданих кредитів номіновані в іноземній валюті (52\% станом на 01.01.2017р.).

Скорочення загального обсягу кредитного портфеля за досліджуваний період відбувалося внаслідок зменшення протягом року суми кредитів, наданих фізичним особам.

За підсумком 2016 р. їх обсяг знизився на $10,43 \%$ до 847,09 млрд грн Кредити, надані суб'єктам господарюванням за підсумком року навпаки збільшилися на $1,98 \%$ та на початок 2017 р. досягли 157,39 млрд грн.

Сьогодні лідером серед банків з впровадження інновацій в Україні є ПриватБанк. Інноваційна політика ПриватБанку орієнтована на впровадження на українському ринку принципово нових, провідних банківських послуг, які надають клієнтам нові можливості управління своїми фінансами.

Приватбанк першим в Україні запропонував своїм клієнтам послуги Інтернет-банкінгу "Приват24" та GSM-банкінгу, а також послуги з продажу через мережу своїх банкоматів та POSтерміналів електронних ваучерів провідних операторів мобільного зв'язку та IP-телефонії [5].

Окрім ПриватБанку, інновації на сьогодні активно впроваджують "Альфа-Банк", "Промінвестбанк", "Райффайзен Банк Аваль" та ін

Аосить великого поширення сьогодні набувають інновації як Private Banking. Елементи Private Banking вже впроваджує ряд українських банків, зокрема, "ПриватБанк", "АльфаБанк", "ОТП Банк", "Укрсиббанк" та інші.

Щодо надання нестандартних банківських послуг VIP-клієнтам, слід відмітити такі: довірче управління активами клієнта та членів його родини, формування банками індивідуальних інвестиційних портфелів VIP-осіб і управління ними, забезпечення фінансового управління на підприємствах, якими володіють такі особи, податкове планування та розроблення 
індивідуальних фінансових схем для оптимізації грошових потоків і т.д.

Окрім надання базових фінансових послуг, часто банки пропонують ряд інших послуг, зокрема, організацію відпочинку, туристичних i ділових поїздок, підбір шкіл для дітей за кордоном, тест-драйв автомобілів класу "дюкс", арт-банкінг.

Сучасний розвиток банківської системи характеризується стрімким зростанням кількості банків, у результаті чого останні змушені шукати нові способи залучення клієнтів.

Теорія та практика аналізу ефективності діяльності банку дає широкий інструментарій Аля їі оцінки, але використання існуючих методик як елементу управління не дозволяє чітко визначити прибутковість окремо взятої послуги, клієнта, структурного підрозділу банку, оскільки ці методики спрямовані на оцінку діяльності банківської установи в цілому. Спроби практиків розподілити доходи та затрати між структурними підрозділами не дозволяють коректно оцінити ефективність певного виду послуг, оскільки спрямовані в багатьох випадках на визначення операційного доходу підрозділу (послуги) без врахування неопераційних (внутрібанківських витрат) або на визначення прибутковості підрозділу без врахування прибутковості послуг [4, с. 763].

На фоні зростання банківського сектору економіки, в умовах загострення конкуренції на ринку банківських послуг, що посилюється ймовірною експансією іноземних банків на вітчизняний ринок, створюються умови, які вимагають підвищення ефективності діяльності банку не за рахунок інтенсифікації, а за рахунок екстенсифікації його діяльності. Одним із таких шляхів $є$ підвищення якості управління банком шляхом запровадження ефективної системи фінансового планування.

Зважаючи на необхідність підвищення рівня надійності, фінансової стійкості банків на внутрішньому й міжнародних ринках, необхідно вжити такі заходи:

- розширити можливості підтримання ліквідності банків на основі програм фінансового оздоровлення,

- збільшити нормативи резервування за кредитними операціями по кредитах, інформацію щодо яких не внесено до кредитних історій,

- оптимізувати структуру капіталу, активів та зобовязань, виходячи із завдань забезпечення фінансової стійкості банків та їх позитивного впливу на розвиток реального сектору економіки;
- посилити вимоги щодо прозорості корпоративного управління банками, зокрема визначення реальних власників банків, та їх відповідальність за підтримання фінансової стабільності банків;

- забезпечити пропорційне зростання регулятивного капіталу та його складових обсягів активно-пасивних операцій;

- підвищити ефективність управління активами і пасивами з метою недопущення необгрунтованого збільшення відрахувань від регулятивного капіталу, зокрема пов'язаних із нарахованими, але не сплаченими доходами;

- розробити стратегічні цілі в залежності від ситуації в країні та за кордоном;

- активніше застосовувати процедуру реорганізації банків шляхом приєднання або злиття, а також реструктуризація банків шляхом закриття збиткових філій.

Серед багатьох факторів, які визначають ефективність банківської діяльності (економічних, правових, організаційних, кадрових тощо) важливе місце посідає також психологічний чинник довіри населення. Він має дві складові: довіра населення до національних грошей - гривні та довіра до банків [7, с. 84].

Підвищення довіри до банків - це актуальне завдання загальнодержавної ваги. Зволікання з її вирішенням може найближчим часом відчутно загальмувати розвиток економіки країни. Тому необхідно невідкладно вживати заходів. Насамперед повинні діяти самі банки. В умовах швидкого загострення конкурентної боротьби вистоять ті з них, які завоюють найвищу довіру населення.

Аля зростання довіри до банків необхідне створення суспільно позитивного іміджу навколо банків. Нині, на жаль, ніхто про такий імідж не дбає, навіть самі банкіри.

Загальноекономічний ефект від зростання довіри населення до банків можна реалізувати за такими напрямами:

— шляхом збільшення ресурсної бази банків завдяки інтенсивнішому припливу вкладів, нарощуванню кредитних та інвестиційних відрахувань в економіку, внаслідок чого поліпшується забезпечення фінансовими ресурсами субєктів господарювання, і, в свою чергу, підвищує фінансовий стан останніх;

- шляхом здешевлення банківських ресурсів, а отже, і кредитів, оскільки, довіряючи банкам, населення нарощуватиме вклади навіть у разі зниження процентних виплат за ними.

Аля зміцнення довіри до банків з боку найкомпетентнішої частини населення важливе значення має послаблення політичних ризиків 
у їх діяльності. Річ у тім, що політичні ризики є найочевиднішими для клієнтів банків і чи не першими застерігають їх від вкладення грошей у банки.

Удосконалення організаційної структури та якості персоналу. Високий рівень управління кадрами забезпечить такі напрями: формування корпоративної культури та поліпшення якості персоналу (рівень освіти, компетенція, навички та професіоналізм); програми мотивації праці та управління чисельністю персоналу.

\section{ВИСНОВКИ 3 ПРОВЕДЕНОГО ДОСЛІДЖЕННЯ І ПЕРСПЕКТИВИ ПОДАЛЬШИХ РОЗВІДОК У ЦЬОМУ НАПРЯМ I}

Аля банків України важливим завданням постає забезпечення свого стабільного розвитку для досягнення найвищих фінансових результатів, також підвищення конкурентоспроможності на внутрішньому та зовнішньому фінансових ринках, посилення взаємодії банків із реальним сектором економіки України. Подальші наші дослідження будуть пов'язані з універсалізацію банку, підвищення якості обслуговування, оскільки розвиток усіх традиційних видів банківських послуг, а також розробка власних, з урахуванням специфіки роботи в Україні і вимог клієнтів, поліпшення якості наданих операцій і послуг.

\ітература:

1. Андрушків T.I. Банки як суб'єкти фінансових ринків України: роль і значення / T.I. Андрушків // Банківська справа. - 1998. № 2. - С. $50-53$.

2. Карминский А.М. Современные тенденции банковских инноваций / А.М. Карминский, О.Р. Жданова // Маркетинг і менеджмент інновацій. - 2013. - № 2. - С. 106-118.

3. Коваленко В.В. Грошово-кредитна політика та її вплив на подолання структурних дисбалансів економіки України / В.В. Коваленко // Глобальні та національні проблеми економіки. - 2016. - № 12. - С. 445-449.

4. Ксьондз, С.М. Сучасний стан банківської системи України [Текст]/ С.М. Ксьондз, А.П. Степанишена // Економіка і суспільство. - 2016. № 7. - С. 761-766.

5. Огляд банківського сектору - НБУ, Випуск 6, лютий 2018 р. [Електронний ресурс]. Режим доступу: https://bank.gov.ua/doccatalog/document?id $=64628171$

6. Основні показники діяльності банків $\mathrm{Y}_{\mathrm{K}-}$ раїни, за даними Національного банку України. [Електронний ресурс]. - Режим доступу: http://www.bank.gov.ua/control/uk/publish/ article?art_id $=36807 \&$ cat_id $=36798$

7. Тарасова, О.В. Стан і тенденції розвитку банківської системи України [Текст]/ О.В. Тарасова, Ю.О. Панова// Економіка харчової промисловості. - 2014. - № 3 (23). - С. 79-86.

8. Чайковський, Я.I. Проблеми та напрямки підвищення ефективності функціонування банківської системи України [Текст]/ Я.І. Чайковський // Економічний аналіз: зб. наук. праць / Тернопільський національний економічний університет; редкол.: В.А. Аерій (голов. ред.) та ін. - Тернопіль: Видавничо-поліграфічний центр Тернопільського національного економічного університету "Економічна думка", 2016. - T. 23. - № 1. - C. 153-160.

\section{References:}

1. Andrushkov, T. I. (1998), "Banks as subjects of the financial markets of Ukraine: the role and significance", Banking, no 2, pp. 50-53.

2. Karminsky, A. M. and Zhdanova, O.R. (2013), "Modern tendencies of banking innovations", Marketing i menedzhment innovacij, No 2, pp. 106-118.

3. Kovalenko, V.V. (2016), "Monetary Policy and its Impact on Overcoming Structural Imbalances in the Economy of Ukraine", Global'ni ta nacional'ni problemi ekonomiki, No. 12, pp. 445449.

4. Ksondz, S.M. and Stepanishhen, A.P. (2016), "Modern state of the banking system of Ukraine", Economy and society, no. 7, pp. 761-766.

5. Overview of the banking sector - National bank of Ukraine (2018), vol. 6, available at: https:/ / bank.gov.ua/doccatalog/document?id=64628171 (Accessed 18 April 2019).

6. Basic indicators of activity of Ukrainian banks, according to the National Bank of Ukraine, available at:http://www.bank.gov.ua/control/uk/ publish/article?art_id $=36807 \&$ cat_id $=36798$ (Accessed 20 April 2019).

7. Tarasova, O. V. and Panov, Yu.O. (2014), "Status and trends of the banking system of Ukraine", Economy of the food industry, no. 3 (23), pp. 79-86.

8. Tchaikovsky, Ya.I. (2016), "Problems and directions of increasing the efficiency of functioning of the banking system of Ukraine", Economic analysis: Sb. sciences works / Ternopil National Economic University; Editorial: V.A. Derii (head ed.) and others. - Ternopil: Publishing and Printing Center of Ternopil National Economic University "Economic Thought", vol. 23, no. 1, pp. 153-160.

Стаття надійшла до редакиії 22.04.2019 p. 


\title{
УAK 331:658
}

С. В. Васильєв, к. е. н., доцент кафедри економіки, Аніпровський Аержавний аграрно-економічний університет, Україна ORCID ID: 0000-0002-4388-4091

А. О. Кривонос, к. е. н., професор кафедри менеАжменту, Аніпровський інститут Приватного акціонерного товариства "Вищий навчальний заклад "Міжрегіональна Академія Управління персоналом", Україна

ORCID ID: 0000-0002-9810-2018

\section{МЕТОАИ ПІАВИЩЕННЯ ЕФЕКТИВНОСТІ УПРАВАІННЯ ПІАПРИСМСТВ УКРАЇНИ В СУЧАСНИХ УМОВАХ}

\author{
S. Vasil'ev, \\ Ph. D. in Economics, Associate Professor of Economics Department \\ Dnipro State Agrarian and Economic University, Ukraine \\ A. Krivonos, \\ Ph. D. in Economics, Professor of Management Department, Dnepr institute of the Private joint-stock company \\ "Higher educational establishment "Interregional Academy of Management a personnel", Ukraine
}

\section{THE METHODS OF ENHANCE THE EFFECTIVENESS OF UKRAINE'S ENTERPRISES MANAGEMENT IN MODERN CONDITIONS}

Розглянуто основні положення методів підвищення ефективності управління підприємств України в сучасних умовах і на основі цього розрахунку чисельності управлінського персоналу.

Аосліджено, що Аля оцінки ефективності апарату управління підприємством, необхідно визначити завантаженість кожного управлінського підрозділу. Аля цього доцільним буде оцінювати ефективність управлінської праці за ії функціями, що дозволить більш обгрунтовано визначити, які фахівці потрібні Аля апарату управління і в якому управлінському підрозАілі є резерв.

Визначено, що кількісно оцінити вплив обсягів змістовного навантаження на ефективність управлінської праці на теперішній час не є можливим. В якості нульового приближення до оцінки цієї величини пропонується підхіА, що базується на порівняльній оцінці змістовного навантаження різних управлінських підрозділів, що функціонують у межах встановленого показника якості.

У статті пропонується визначити ефективність управління в залежності від обсягів змістовного навантаження на співробітників управлінських підрозділів у відносних величинах, що надасть можливість аналізувати діяльність підрозділів незалежно від їх спеціалізації.

Результатом застосування методики $є$ формування рекомендацій щодо удосконалення стратегії розвитку системи управління персоналом підприємства, що дадуть змогу зАійснювати контроль за оптимальною завантаженістю управлінських робітників; розрахувати оптимальну чисельність управлінських підрозділів; регулювати ефективність управлінської праці.

The main provisions of the enhance the effectiveness methods of Ukrainian enterprises management in modern conditions and the number of management personnel is based on this calculation are considered.

This requires the development of methodological provisions for optimizing the workload of the management units, which will promotes efficiency of management and reduce management costs. 
It is investigated that in order to assess the efficiency of enterprise management, it is necessary to determine the load capacity of each administrative unit.

For this purpose, it will be useful to assess the management effectiveness for its functions, which will allow more reasonably to determine what specialists are needed for the management and in which management unit has a reserve.

If the factor of time is taken as a criterion for the management functions classification, then they could be considered as successive stages of the implementation of managerial influence on the production process.

It is determined that it is not possible to quantify the impact of volumes of content load on the efficiency of managerial labor at the present time.

As a zero approximation to the estimation of this value, an approach based on a comparative assessment of the content load of various management units operating within the established quality index is proposed.

The indicator of the rhythm of work could be selected on the role of the normative quality indicator in this case.

In the article proposes to determine the management effectiveness according to the amount of content load on employees of administrative units in relative terms, which will enable the analysis of the activities of units, regardless of their specialization.

The organizational and economic mechanism for managing the company's efficiency that is proposed by authors has universal character and could applied to any enterprise of any branch of social production.

The result of the application of the method are to formulate recommendations for improving the strategy of development of the personnel management system of the enterprise, which will enable to control the optimal workload of the managerial workers; calculate the optimal number of administrative units; regulate the effectiveness of managerial work.

Ключові слова: підприємство, управління, економічна ефективність, змістовне навантаження в управлінні.

Key words: enterprise, management, economic efficiency, content management.

\section{ПОСТАНОВКА ПРОБЛЕМИ}

Аосягнення необхідного рівня конкурентоспроможності підприємств в Україні у разі входження в середовище вільного простору європейського ринку, що сформувався в умовах жорсткої політичної та економічної конкуренції, на тлі діючих європейських стандартів, конче потрібен відповідальний підхід у прийнятті того чи іншого методу корегування управлінської діяльності.

Прийнявши до уваги дійсне положення підприємств України в рейтингах європейських ринків, а також розбіжності концептуального плану, які склалися у наслідок історичної та геополітичної обстановки, треба відмітити слабкість вітчизняного управлінського персоналу в порівнянні з європейським. Безперечно результат менеджменту - це техніко-економічні показники підприємства. Навіть у цьому випадку на підприємстві у механізмах керування персоналом відсутні чіткі, а інколи й загальноприйняті методи підвищення ефективності управління. 3 огляду на вказане, суттєвого значення на сьогодні отримує підвищення ефективності управлінської праці.

\section{АНАЛІЗ ОСТАННІХ ДОСЛІДЖЕНЬ І ПУБЛІКАЦІЙ}

Проблематика ефективності процесу управління в умовах нестабільного як внутрішнього, так і зовнішнього середовища досліджена в наукових працях такими вченими: Б.М. Андрушків, І.О. Бланк, В.П. Галенко, Й.С. Завадський, I.I. Мазур, В.А. Шапіро, А.В. Шегда, В.В. Юрчишин, П. Арукер, Е. Мейо, К. Норт та іншими вітчизняними та зарубіжними науковцями. Аналіз наукових думок зазначених авторів дає підстави стверджувати, що єдиної точки зору щодо трактування та оцінювання ефективності управління досі не сформовано. Разом із тим збільшилася неоднозначність визначення ефективності управління та урізноманітнилися її показники оцінки.

\section{META CTATTI}

Метою статті $€$ пропозиція науково-обгрунтованого метода удосконалення системи управління на підприємствах. Це потребує розробки методичних положень оптимізації навантаження робітників управлінських підрозділів, що сприятиме підвищенню ефективності управ- 
Таблиця 1. Взаємозв'язок функцій, завдань управління та їх результатів

\begin{tabular}{|l|l|l|}
\hline \multicolumn{1}{|c|}{$\begin{array}{c}\text { Функції } \\
\text { управління }\end{array}$} & \multicolumn{1}{|c|}{ Завдання управління } & \multicolumn{1}{|c|}{$\begin{array}{c}\text { Результати виконання } \\
\text { функцій }\end{array}$} \\
\hline Планування & $\begin{array}{l}\text { Обгрунтування темпів } \\
\text { пропорційного кількісного і } \\
\text { якісного розвитку виробничої } \\
\text { системи }\end{array}$ & $\begin{array}{l}\text { Плани економічного, } \\
\text { соціального, науково- } \\
\text { технічного розвитку } \\
\text { виробництва }\end{array}$ \\
\hline Регулювання & $\begin{array}{l}\text { Створення стійкості, стабільності } \\
\text { виробництва }\end{array}$ & $\begin{array}{l}\text { Затвердження стандартів } \\
\text { і норм }\end{array}$ \\
\hline Координування & $\begin{array}{l}\text { Встановлення взаємозв'язку } \\
\text { підрозділів в системі виробництва, } \\
\text { маневрування ресурсами у } \\
\text { відповідності зі зміною завдань }\end{array}$ & $\begin{array}{l}\text { Затвердження графіків, } \\
\text { розпорядку роботи, } \\
\text { корегування планів }\end{array}$ \\
\hline Контроль & $\begin{array}{l}\text { Кількісна і якісна оцінка та облік } \\
\text { результатів дійсного стану справ. } \\
\text { Перевірка рішень, пов'язаних з } \\
\text { розвитком виробництва }\end{array}$ & $\begin{array}{l}\text { Рішення по результатам } \\
\text { обліку, перевірок, ревізії } \\
\text { тощо }\end{array}$ \\
\hline \multicolumn{2}{|l}{}
\end{tabular}

лінської праці і скороченню видатків на управління.

\section{РЕЗУЛЬТАТИ ДОСЛІДЖЕННЯ}

У науковій літературі розглядається багато підходів, як схожих між собою, так і зовсім різних, щодо оцінки ефективності управління. Основна причина існування такої їх різноманітності полягає в тому, що управління тісно пов'язане з усіма економічними та соціальними процесами, що відбуваються на підприємстві. На думку професора П. Березівського, ефективність виробничого сектору економіки лише на третину зумовлюється вкладеннями в техніку й устаткування, а все інше залежить від людського чинника, а саме інтелектуального потенціалу, кваліфікаційного рівня, здібностей керівників і спеціалістів [2]. Як стверджує професор Юрчишин В.В. [10], ще однією особливістю сучасного етапу розвитку системи управління є відсутність необхідної єдності нових форм організації виробництва і управління та ї змісту. Помітна питома вага управлінського персоналу свідчить про збереження на підприємствах практично незмінної структури системи управління, i, як наслідок, великої кількості закріплених за управлінцями зон контролю багатьох параметрів виробництва.

Систематизація існуючих підходів до оцінювання ефективності управління зроблена у праці Т. Коваленко [5] може бути також доповнена новими, що представлені в наукових працях інших авторів [1].

Окрім підходів до оцінювання ефективності управління, які були виділені Агатаєвою А.А., існують й інші методи оцінювання ефективності управлінської праці. Так, у праці $\Lambda$. Тараєвської пропонується визначати ефективність управління в залежності від обсягів змістовного навантаження [8]. Такий підхід в сучасній рин- ковій економіці набуває вирішального значення і потребує подальшого дослідження.

У статті пропонується визначити ефективність управління в залежності від обсягів змістовного навантаження на співробітників управлінських підрозділів. Реальний результат управлінської праці відображається в кінцевому рахунку в техніко-економічних показниках господарської діяльності в цілому. При отриманні заданих (або навіть покращених) показників доцільно говорити про достатньо високу ефективність управлінської праці. Однак навіть в такому випадку на підприємствах нерідко має місце нерівномірність навантаження управлінських підрозділів, що значно знижує ефективність управління. Причинами такого навантаження можуть бути неправильний розподіл робіт між підрозділами і нерівномірний розвиток підрозділів.

Таким чином, щоб оцінити ефективність апарату управління підприємством, необхідно визначити завантаженість кожного управлінського підрозділу.

Відомо, що діяльність апарату управління спрямована на те, щоб об'єднати всі функції управління. Отже, доцільним буде оцінювати ефективність управлінської праці за її функціями, що дозволить більш обгрунтовано визначити, які фахівці потрібні для апарату управління і в якому управлінському підрозділі $€$ резерв.

Управлінню притаманним є розподіл праці за функціями управління, тобто за ділянками управлінської діяльності, відокремленими під впливом як об'єкта управління виробництвом, так і закономірностями самого управління. Особливістю праці робітників апарату управління є велика питома вага розумових (творчих і логічних) операцій. Обсяг таких робіт пов'язаний зі змістовним навантаженням. 
Якщо в якості критерію класифікації функцій управління візьмемо фактор часу, то їх можна розглядати як послідовні етапи реалізації управлінського впливу (табл. 1). Отже, управлінську працю можна поділити на такі складові: $\mathrm{x}_{1}-$ планування, $\mathrm{x}_{2}-$ регулювання, $\mathrm{x}_{3}$ - координування, $\mathrm{x}_{4}$ - контроль.

Кожна функція здійснює вплив на інші функції і всі вони об'єднані в спільний процес управління. Отже, ефективність управління буде залежати від ефективності функціонування кожної із його складових. Тоді ефективність управління:

$$
\mathrm{E}_{\text {ф. упр }}=\mathrm{F}\left(\mathrm{x}_{1}, \mathrm{x}_{2}, \mathrm{x}_{3}, \mathrm{x}_{4}\right) \text {. }
$$

Вплив кожної складової функції управління на ефективність всього управління буде різним. На практиці має місце одночасне виконання підрозділом декілька функцій. Аослідження окремих функцій дає можливість зрозуміти сутність механізму управління, усунути залишкові ланцюги, підвищити ефективність діяльності апарату управління. Тому є доцільним визначити обсяги робіт підрозділів, пов'язаних зі здійсненням виконання ними функцій. Таке визначення може бути здійснено на основі експертних оцінок.

Аіяльність управляючого апарату в цілому і виконання кожної його функції складається під впливом різноманітних факторів, які здійснюють вплив на обсяг робіт управлінських підрозділів [2].

Попередній вибір факторів, що впливають на працеємкість робіт, здійснюється на основі логічного аналізу причин зміни працеємкості виконання окремих управлінських робіт. На цьому етапі для дослідження може застосовуватися велика кількість факторів, але вони повинні відповідати вимогам дієвості (здійснювати вплив на величину працеємкості робіт або відображати відмінності в техніко-організаційним умовам виконання робіт) і стабільності (не коливатися дуже різко по місяцям).

Вибір основних факторів дозволить вирішити важливу проблему - очистити основні показники управлінської праці від впливу другорядних явищ. Крім того, представлення єдиної якості як сукупності його складових має певні переваги. Набагато простіше дати оцінку по окремим критеріям. Якщо декілька експертів оцінюють вплив одного фактору, то можливо, що їх думки можуть розходитися. Практика показує, що ці розходження значно сильніші при оцінці впливу в цілому. При оцінці по окремим критеріям збіг точок зору експертів набагато більше, оскільки оцінка по окремому критерію не дуже складна і має більш чіткий зміст.
Визначення виробничих факторів та їх значимість в обсязі робіт управлінських підрозділів також можна оцінити методом експертних оцінок [7]. Експертам з числа провідних фахівців підприємства (начальників відділів, головних спеціалістів) пропонується перелік факторів, які можуть здійснювати вплив на складність та обсяги робіт управлінських підрозділів. При цьому слід зауважити, що серед найбільш істотних факторів можуть опинитися такі, між якими існує кореляція (наприклад, між чисельністю основних робітників і кількістю робочих місць). Такі фактори не повинні включатися у перелік для однієї і тієї ж функції управління.

Зростаючий обсяг управлінської роботи, який раніше виконувався завдяки збільшення кількості робітників у сфері управління, на сучасному етапі передбачає інший, більш раціональний шлях - підвищення ефективності праці робітників управління.

Враховуючи, що складність функцій управління неоднакова, тому різні і величини змістовного навантаження на управлінські підрозділи. Одним із головних факторів, що визначають зміст управління підприємством, $€$ взаємозв'язок його підрозділів. Цей зв'язок знаходить прояв у вигляді потоків інформації, яку підрозділи, що виконують функції управляння, використовують при прийнятті рішень і за допомогою якої передають управлінський вплив на виробництво.

Між обсягом інформації і складністю управління існує пряма залежність. Чим складніший процес управління, тим більший обсяг інформації, тим більша кількість управлінських робітників потрібна цьому виробничому об'єкту.

Метод визначення змістовного навантаження, що пропонується, заснований на використанні звітних кількісних показників. Зазвичай абсолютні значення факторів, що визначають кількість інформації і складність функції управління, представлені у непорівнянних величинах (обсяг продукції, серійність виробництва, норма витрачання матеріалів та ін.). Тому $є$ доцільним визначати обсяг змістовного навантаження на управлінські підрозділи у відносних величинах. Це надасть можливість аналізувати діяльність підрозділів незалежно від їх спеціалізації.

В основу цього методу покладений той факт, що управлінські підрозділи виконують одночасно декілька функцій управління. Причому, як це було зазначено вище, обсяги виконання цих функцій кожним підрозділом $є$ різними. 


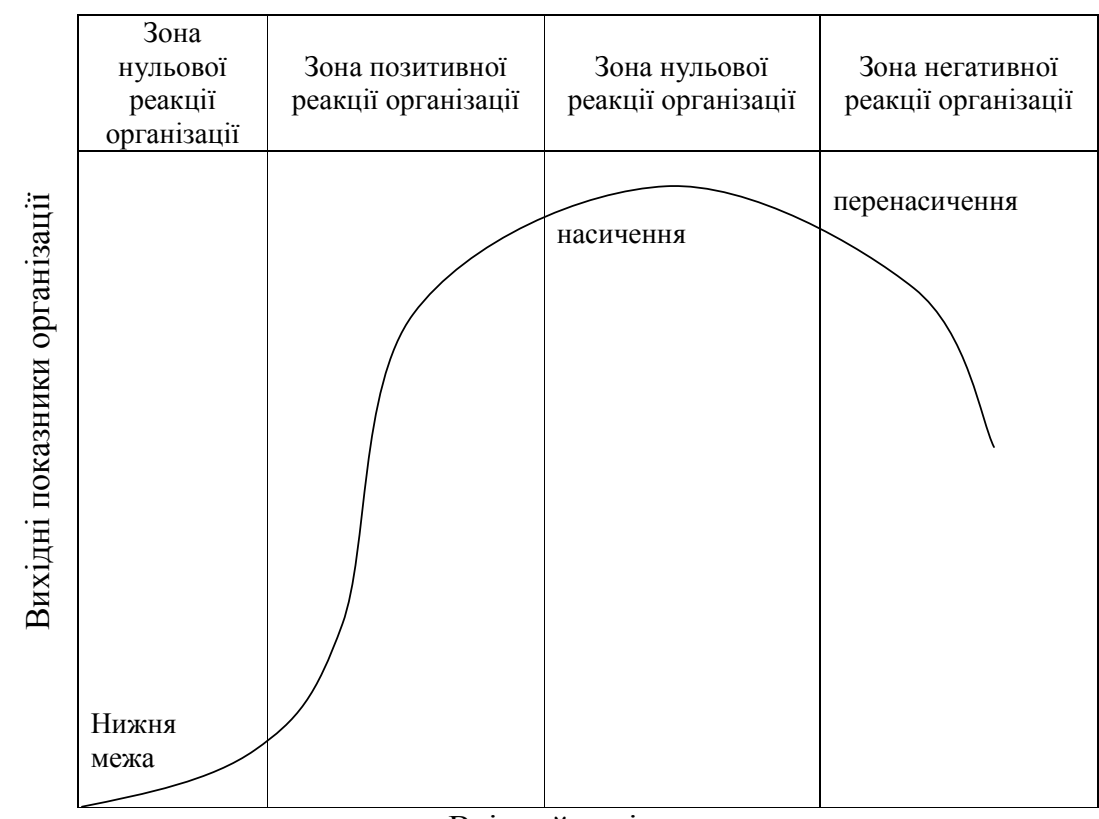

Вхідний потік

Рис. 1. Реакція організації на чисельність персоналу

Аля того, щоб визначити повний обсяг змістовного навантаження, необхідно спочатку визначити обсяг цього навантаження (K), зумовлений впливом кожного фактору окреMO:

$\mathrm{K}=\mathrm{P}_{\text {пит } 1, \mathrm{~g}} \times \mathrm{K}^{\prime}$

де $\mathrm{P}_{\text {пит } 1, \mathrm{~g}}$ - питома вага 1-ої функції управління в обсязі робіт g-го підрозділу;

$\mathrm{K}^{\prime}$ - коефіцієнт відносної участі.

$\mathrm{K}^{\prime}=1 / \mathrm{u}$,

де u - кількість підрозділів, для яких фактор, що розглядається, є визначальним.

Після вибору виробничих факторів і визначення окремих коефіцієнтів змістовного навантаження можна розрахувати повний коефіцієнт змістовного навантаження 1-ої функції управління.

$\mathrm{K}_{\Pi}=\Sigma \mathrm{K} \phi$

де $\mathrm{K}_{1}, \mathrm{~K}_{2}, \mathrm{~K}_{3}, \ldots \ldots ., \mathrm{K}_{\phi}$ - окремі коефіцієнти; ф- кількість факторів.

Підставив у формулу (1) значення окремих коефіцієнтів із формули (2), отримаємо наступну формулу розрахунку повного коефіцієнта змістовного навантаження для підрозділу по даній функції управління:

$\mathrm{K}_{\text {пg }}=\mathrm{P}_{\text {пит } 1, \mathrm{~g}} \times \mathrm{K}_{1}^{\prime}+\mathrm{P}_{\text {пит } 1, \mathrm{~g}} \times \mathrm{K}_{2}^{\prime}+\ldots+\mathrm{P}_{\text {пит } 1, \mathrm{~g}} \times \mathrm{K}_{\phi}^{\prime}$.

Метод визначення змістовного навантаження дозволяє шляхом нескладних розрахунків визначити відносну завантаженість управлінських підрозділів.

Повний коефіцієнт змістовного навантаження по всім функціям, що виконуються g-им підрозділом, тобто його повне змістовне навантаження:
$\mathrm{Ng}=\Sigma \mathrm{K}_{\mathrm{ng} 1,} 1=1,2,3,4$,

де $\mathrm{Ng}$ - повне змістовне навантаження $g$ го підрозділу;

$\mathrm{K}_{\mathrm{g}}$ - повний коефіцієнт змістовного навантаження g-го підрозділу по $l$-й функції управління.

Кількісно оцінити вплив обсягів змістовного навантаження на ефективність управлінської праці на теперішній час не $є$ можливим. В якості нульового приближення спробуємо визначити загальний характер такої залежності на основі концептуальних уявлень.

Відомо, що при дуже низькому навантаженні ефективність наближується до нулю. Поперше, це пов'язано з тим, що людина яка знаходиться на роботі, так чи інакше витрачає весь свій час безповоротно і якщо за цей час вирішується дуже мало управлінських завдань, то ефективність $\dddot{1} є є$ низькою. По-друге, при дуже низькому навантаженні вступають у дію психологічні фактори: людина втрачає інтерес до роботи, відчуття відповідальності, професіоналізм і в кінці кінців виконує дуже погано навіть те, що йому доручено.

3 іншого боку, зрозуміло, що при високих навантаженнях людина не встигає справлятися з усіма завданнями і починає вирішувати їх по спрощеному алгоритму (по аналогії, за натхненням), не особливо вникаючи в їх специфіку. Чим вищим буде навантаження, тим більший відсоток таких завдань, які вирішуються неадекватними методами. Таким чином, людина звикає до подібного стилю, у неї атрофується відчуття відповідальності, втрачається істин- 
ний професіоналізм і замість цього формується так званий "професіоналізм" бюрократичний - здатність швидко "відмовитися" від будьякого складного запитання. В результаті не вирішується по справжньому навіть той невеликий відсоток завдань, який міг би бути вирішений на достатньо високому рівні.

Отже, при занадто високих змістовних навантаженнях ефективність також, як і при занадто низьких, наближується до нулю (рис. 1). 3 цього можна зробити висновок, що існує таке навантаження, яке відповідає максимальній ефективності, яку можна вважати оптимальною.

Наведене вище непрямо підтверджується даними досліджень закордонних вчених, в яких показана залежність загального ефекту, що досягає організація, від чисельності персоналу [4]. Оскільки при фіксованому обсязі завдань зростання чисельності є адекватним зниженню змістовного навантаження, то це співпадає з тенденцією побудованою на основі загальних концептуальних уявлень.

Питання масштабування кривої, представленої на рисунку 1 , тобто прив'язка її до конкретних величин навантаження та ефективності і визнання конкретного значення оптимального навантаження залишається поки що відкритим. У цій статті в якості нульового приближення до оцінки цієї величини пропонується підхід, що базується на порівняльній оцінці змістовного навантаження різних управлінських підрозділів, що функціонують в межах встановленого показника якості. На роль нормативного показника якості може бути вибраний показник ритмічності роботи. В такому випадку в управлінських підрозділах, які ритмічно функціонують, питоме змістовне навантаження близьке до оптимального, буде мати те, в якому це навантаження $€$ найбільшим. Слід підкреслити, що це буде справедливим за умови збереження ритмічності роботи. Якщо питоме змістовне навантаження перевищить оптимальне, то у відповідності до кривої на рисунку 1 , ефективність роботи повинна знизитися, і це, зазвичай, в першу чергу відобразиться на ритмічності роботи.

Якщо визначене таким чином питоме змістовне навантаження прийняти в якості оптимального, то логічно поставити завдання вирівнювання змістовного навантаження між окремими управлінськими підрозділами. Одним 3 ефективних способів такого вирівнювання $€$ перерозподіл чисельності управлінських підрозділів.

Обгрунтованою є така чисельність робітників апарату управління і окремих його ланцюгів, яка забезпечує повне завантаження кож- ного робітника упродовж року і можливість якісного і своєчасного виконання робіт.

Оптимізація чисельності, на наш погляд, може бути досягнута шляхом находження нормованого співвідношення між чисельністю робітників за всіма функціями управління на основі оптимальної величини обсягу змістовного навантаження. Аля цього здійснюються розрахунки на основі питомого оптимального змістовного навантаження базових підрозділів підприємств. Базовий підрозділ вибирається наступним чином:

1) зі всіх підрозділів відбираються ті, які функціонують ритмічно, всі інші підрозділи в подальшому аналізу участі не прияють;

2) з вибраних підрозділів базовим приймається той, в якому питоме змістовне навантаження буде найбільшим.

При цьому чисельність управлінських підрозділів підприємства, що мають величину питомого змістовного навантаження нижче базового рівня, повинна зменшуватися. Це приведе до збільшення обсягу змістовного навантаження на кожного робітника підрозділу і, відповідно, підвищить ефективність праці.

Таким чином, ситуацію, коли за відсутності норм для управлінських робіт на однакових підприємствах і в однакових управлінських підрозділах є різна кількість робітників управління, усувається. Зміною чисельності управлінських підрозділів можна зробити однаковою завантаженість робітників управління в аналогічних підрозділах різних підприємств.

\section{вИСнОВки}

1. Розподіл процесу праці управлінських підрозділів на складові функції управління, які визначаються як послідовні етапи реалізації управлінського впливу, надає можливість здійснити оцінку завантаженості управлінських підрозділів.

2. Обсяг роботи і чисельність управлінських підрозділів залежать від багатьох виробничих факторів, які визначають потужність виробництва. Вплив цих факторів знаходить прояв у вигляді обсягів змістовного навантаження як непрямого відображення обсягу інформації і обсягу роботи апарату управління.

3. Залежність ефективності управлінської праці від обсягів змістовного навантаження знаходить вираз у вигляді кривої колообразного типу.

4. Визначення обсягу змістовного навантаження дозволить:

- здійснювати контроль за оптимальною завантаженістю управлінських робітників, 
- розрахувати оптимальну чисельність управлінських підрозділів, праці.

- регулювати ефективність управлінської

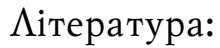

1. Агатаева А.А. Управленческие решения, которые типичны для функций менеджмента / А.А. Агатаева // Materialy XII mezinarodni vedecko - praktika conference. - Praha.: Publishing House "Education and Science" s.r.o., 2016. - s. 33-35.

2. Березівський П.С. Організація виробництва і підприємницької діяльності в аграрних формуваннях: навч. посібник / П.С. Березівський, Ю.Е. Губені, Н.І. Михалюк: за ред. П.С. Березівського. - - ьвів: Укр. Технології, 2002. $-536 \mathrm{c}$.

3. Гудзій 3.М. Впровадження вартісноорієнтованого управління як елемент підготовки компанії до виходу на європейські ринки капіталу / 3.M. Гудзій // Матеріали IV всеукраїнської науково-практичної Інтернет-конференції. ційної академії, 2015. - С. 71-73.

4. Исследование операций. Т. 2. Модели и применения / Под ред. Аж. Моудера, С. Элмагради: Пер. с англ. Под. ред. И.М. Макарова, И.М. Бескровного. - М.: Мир, 1981. - 677 с.

5. Коваленко Т. Система показників комплексної оцінки управління персоналом/ Т. Коваленко // [Електронний ресурс]. - Режим доступу: http://ea.donntu.edu.ua/bitstream/ 123456789/14912/1/тернополь $1 . p d f$

6. Кривонос А.О., Прокопенко Ю.О. Адаптація менеджменту підприємств сучасної України в умовах європейської інтеграції/ А.О. Кривонос, Ю.О. Прокопенко // Materialy XII mezinarodni vedecko - praktika conference. Praha.: Publishing House "Education and Science" s.r.o., 2016. - S. 34-37.

7. Аепа Р.Н. Влияние качества управленческих решений на эффективность функционирования предприятия/P.Н. Аепа [Електронний ресурс].Режим доступу: http://dspace.nbuv.gov.ua/ bitstream/handle/123456789/2943/St_34_13.pdf

8. Тараєвська $\Lambda$., Ріщук $\Lambda$. Методичні підходи до оцінки рівня управління організацією / $\Lambda$. Тараєвська, $\Lambda$. Ріщук // Економічний аналіз. - 2013. - T. 12 (4). - С. 79-83.

9. Щекин Г.В. Теория и практика управления персоналом: учеб. метод. пособ. - 2-е изд. — К.: МАУП, 2007. - 208 с.

10. Юрчишин В.В. Науково-методологічні та організаційні основи розвитку систем управ- ління аграрним сектором економіки / В.В. Юрчишин // Економіка АПК. - 2003. - № 1. C. $17-25$.

\section{References:}

1. Ahataeva, A.A. (2016), "Management decisions that are typical of management functions", Materialy XII mezinarodni vedecko - praktika conference, Praha: Publishing House "Education and Science, pp. 33-35.

2. Berezivskiy, P. Gubeny, Yu. and Muyhalyuk, N. (2002), Orhanizatsiia vyrobnytstva i pidpryiemnyts'koi diial'nosti v ahrarnykh formuvanniakh [Organization of production and entrepreneurial activity in the agrarian forming], Ukr. Tekhnolohii, L'viv, Ukraine.

3. Hudzij, Z.M. (2015), "The introduction of value-oriented management as an element of preparation for the company to enter the European capital markets", Materialy IV vseukrains'koi naukovo-praktychnoi Internet-konferentsii [Conference proceedings of IV Ukrainian scientific and practical Internet-conference], Lviv, Ukraine, pp. 71-73.

4. Moder, Joseph J. and Elmaghraby, Salah E. (1981), Operations Research. Models and Applications, Moscow, Mir, 677 p.

5. Kovalenko, T. (2011), "System of indicators of integrated assessment of personnel management" [Online], availableat: http://ea.donntu.edu.ua/bitstream/123456789/14912/1/ тернополь1.pdf (Accessed 30 March 2019).

6. Kryvonos, A.O. and Prokopenko, Yu.O. (2016), "Adaptation of management of enterprises of modern Ukraine in conditions of European integration", Materialy XII mezinarodni vedecko - praktika conference [Conference proceedings of XII international scientific and practical conference], Praha.: Publishing House 'Education and Science" s.r.o., pp. $34-37$.

7. Lepa, R.N. (2006), "The impact of quality management decisions on the enterprises' efficiency" [Online], available at: http://dspace.nbuv.gov.ua/bitstream/handle/123456789/2943/ St_34_13.pdf (Accessed 12 April 2019).

8. Taraievs'ka, L. and Rischuk, L. (2013), "Methodological approaches to assessing the level of management of an organization", Ekonomichnyj analiz, vol. 12 (4), pp. 79-83.

9. Schekyn, H.V. (2007), "Theory and practice of personnel management", Kyiv, MAUP, 208 p.

10. Yurchyshyn, V.V. (2003), "Scientific, methodological and organizational foundations for the development of agrarian sector management systems", Ekonomika APK, vol. 1, pp. 17-25. Стаття надійшла до редакиії 02.05.2019 p. 


\title{
А. В. Ковальов,
} к. с.-г. н., Аоцент, доцент кафедри загальноекономічних дисциплін, Аержавний вищий навчальний заклаА "Херсонський державний аграрний університет", м. Херсон

\section{ОЦІНКА КЛЮЧОВИХ ТЕНАЕНЦІЙ У ТРАНСФОРМАЦІЇ ЗАЙНЯТОСТІ НАСЕЛЕННЯ ХЕРСОНСЬКОÏ ОБААСТI ТА ЗМIH У ÏÏ СТРУКТУРI}

\author{
D. Kovalyov, \\ Candidate of Agricultural Sciences, Associate Professor, Department of General Economics, \\ State Higher Educational Institution "Kherson State Agrarian University", Kherson
}

\author{
ASSESSMENT OF KEY TENDENCIES IN TRANSFORMATION OF EMPLOYMENT \\ OF POPULATION OF KHERSON REGION AND CHANGES IN ITS STRUCTURE
}

\begin{abstract}
У статті систематизовано сучасні негативні тенденції формування та розвитку ринку праці. Надано характеристику рівня зайнятості та економічної активності населення з розподілом за видами економічної діяльності, за статтю та місцем проживання, віковими групами, за освітою, а також проаналізовано попит та пропозицію робочої сили за професійними групами у 2014-2017 pр. На основі проведеної оцінки встановлено, що проблемою у Херсонській області залишається значний професійно-кваліфікаційний дисбаланс на ринку праці. Проведені дослідження довели, що основними причинами такого дисбалансу є структурні диспропорції в національній економіці, зміни статевовікової структури населення, відсутність механізму забезпечення наступності поколінь за окремими професіями. Аоведено, що структура зайнятості у Херсонській області є протилежної високо розвинутим країнам, оскільки більша частина трудового потенціалу, порівняно з іншими галузями, припадає на галузі матеріального виробництва. Спостерігається досить низький рівень зайнятості сфер обслуговування самої людини.
\end{abstract}

The article is given the description of level of employment and economic activity of population with division according to the types of economic activity, gender and location, age groups, education and also it is analyzed supply and demand of workers to their professional groups within 2014-2017 years.

On the base of assessment, it is determined that during the period from 2014 till 2017 the quantity of employed population has been shortened on 8 thousand persons aged 15-70 and on 1.300 persons of working age. The level of employment of working age population was $66.3 \%$.

Researches proved that shortening of structural indicators of employment touched such kinds of economic activity as: extractive industry and open - cast mines $-50 \%$, activity in the sphere of administrative and auxiliary exploitation $25 \%$. 
The most growth of structural indicators of employment were in the State management and defense, compulsory social insurance $-\mathbf{1 1 . 1} \%$.

The level of employment of population on the 1 -st of January 2018 was $56.2 \%$, employment among men was on $16.8 \%$ higher than among women. The level of employment of population that locate in countryside is on $9 \%$ higher than in the urban settlements.

The level of employment in 2017 was $\mathbf{6 6 . 0 \%}$ for the people with complete higher education, for the people that have incomplete higher education $-\mathbf{5 9 . 4 \%}$ and basic higher education $-\mathbf{5 3 . 9 \%}$. Workers with professional-technical education are also in demand among employers, their level of employment is $62.5 \%$. The least demanded are the people with primary general education or the people that have not any education $-10.1 \%$.

As for demand from the side of employers, it is raised among technical workers, workers in the sphere of trade, services and qualified workers of rural and forest manufacturing, fish-breeding and fishing industry.

The analysis of statistics proves that the structure of employment in Kherson region is in opposition to highly developed countries because of the most part of labor potential in comparison with other branches are the branches of material manufacturing. It is observed rather low level of employment of the spheres of service of a person himself: education, health protection, science, social guaranteeing and others.

Ключові слова: ринок прачі, зайнятість, безробіття, постіндустріальна економіка, трансформачіл структури зайнятості.

Key words: labor market, employment, unemployment, post-industrial economy, transformation of employment structure.

\section{ПОСТАНОВКА ПРОБЛЕМИ}

У процесі становлення постіндустріального суспільства трансформується сфера зайнятості. Це відбувається, перш за все, відповідно до змін у структурі економіки регіону. При цьому потрібні докорінні структурні зміни, що породженні функціональними завданнями кожної із галузей економіки та перспективами їх розвитку. В такому випадку значної актуальності набуває потреба у дослідженні структури зайнятості населення Херсонської області за видами економічної діяльності. Неоднорідний розвиток сфер економічної діяльності та галузей економіки під дією цілого ряду факторів обумовив значні зрушення у галузевій структурі та динаміці зайнятого населення. У зв'язку з цим виникає необхідність у проведенні аналізу тенденцій розвитку, інерційних процесів та проявів турбулентного стану ринку праці, зокрема сфери зайнятості.

\section{АНАЛІЗ ОСТАННІХ ДОСЛІДЖЕНЬ І ПУБЛІКАЦІЙ}

Проблеми трансформації зайнятості в умовах переходу до інформаційного суспільства, впливу інформаційних технологій на занятість та формування нового співвідношення між зайнятістю та безробіттям досліджено у працях Р. Арона, О. Тоффлера, Я. Корнаї, М. Барінова, П. Нікіфорова, Т. Власенко, В. Гутника, $\Lambda$. Шевчука та ін.

Комплексному аналізу різноманітних аспектів ринку праці, зокрема, сфери зайнятості, присвячено багато досліджень. Найбільш дотичною у цій сфери є монографія В.В. Онікієн-

Таблиця 1. Зайняте населення Херсонської області у 2014-2017 рр.

\begin{tabular}{|c|c|c|c|c|}
\hline \multirow{4}{*}{ Роки } & \multicolumn{4}{|c|}{ Зайняте населення } \\
\cline { 2 - 5 } & $\begin{array}{c}\text { у віці 15-70 років } \\
\text { середньому, } \\
\text { тис. осіб }\end{array}$ & $\begin{array}{c}\text { у \% до } \\
\text { населення } \\
\text { відповідної } \\
\text { вікової групи }\end{array}$ & $\begin{array}{c}\text { працездатного віку } \\
\text { в середньому, } \\
\text { тис. осіб }\end{array}$ & $\begin{array}{c}\text { у до } \\
\text { населення } \\
\text { відповідної } \\
\text { вікової } \\
\text { групи }\end{array}$ \\
\hline 2014 & 450,2 & 56,4 & 434,4 & 65,3 \\
\hline 2015 & 445,8 & 56,1 & 436,4 & 65,7 \\
\hline 2016 & 441,0 & 55,8 & 432,1 & 65,1 \\
\hline 2017 & 442,2 & 56,2 & 433,1 & 66,3 \\
\hline
\end{tabular}

Ажерело: розраховано за даними [5]. 
Таблиця 2. Безробітне населення Херсонської області у 2014-2017 рр.

\begin{tabular}{|c|c|c|c|c|}
\hline \multirow[b]{3}{*}{ Роки } & \multicolumn{4}{|c|}{ Безробітне населення (за методологією МОП) } \\
\hline & \multicolumn{2}{|c|}{ у віці $15-70$ років } & \multicolumn{2}{|c|}{ працездатного віку } \\
\hline & $\begin{array}{c}\text { в } \\
\text { середньому, } \\
\text { тис. осіб }\end{array}$ & $\begin{array}{c}\text { у \% до } \\
\text { економічно } \\
\text { активного } \\
\text { населення } \\
\text { відповідної } \\
\text { вікової групи }\end{array}$ & $\begin{array}{c}\text { в } \\
\text { середньому, } \\
\text { тис. осіб }\end{array}$ & $\begin{array}{c}\text { у \% до } \\
\text { економічно } \\
\text { активного } \\
\text { населення } \\
\text { відповідної } \\
\text { вікової групи }\end{array}$ \\
\hline 2014 & 49,6 & 9,9 & 49,6 & 10,2 \\
\hline 2015 & 50,8 & 10,2 & 50,8 & 10,4 \\
\hline 2016 & 55,9 & 11,2 & 55,9 & 11,5 \\
\hline 2017 & 55,0 & 11,1 & 55,0 & 11,3 \\
\hline
\end{tabular}

Ажерело: розраховано за даними [5].

ко [1], у якої розглядаються економічні, політичні, демографічні, соціальні та інші процеси, які значною мірою впливають на попит та кваліфікацію працівників, рівень зайнятості і безробіття. Нормативно-правовий та організаційно-економічний механізм регулювання ринку праці досліджено в працях Ю.М. Маршавина
[2], О.В. Чернявської [3]; Я.А. Жаліло [4] окреслив передумови, ризики, шляхи подолання системної кризи в Україні.

\section{ПОСТАНОВКА ЗАВДАННЯ}

Метою дослідження є визначення стану зайнятості населення Херсонської області в су-

Таблиця 3. Зайнятість населення за видами економічної діяльності, тис. осіб

\begin{tabular}{|c|c|c|c|c|c|}
\hline Показники & 2014 p. & 2015 p. & 2016 p. & 2017 p. & 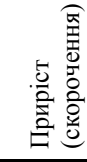 \\
\hline Усього & 450,2 & 445,8 & 441,0 & 442,2 & $-8,0$ \\
\hline $\begin{array}{l}\text { Сільське, лісове господарство та рибне } \\
\text { господарство }\end{array}$ & 131,5 & 128,8 & 130,3 & 135,1 & $+3,6$ \\
\hline Промисловість & 44,4 & 40,9 & 39,8 & 39,4 & $-5,0$ \\
\hline \multicolumn{6}{|l|}{ у тому числі } \\
\hline $\begin{array}{l}\text { Добувна промисловість і розроблення } \\
\text { кар'єрів }\end{array}$ & 0,2 & 0,2 & 0,1 & 0,1 & $-0,1$ \\
\hline Переробна промисловість & 32,4 & 29,9 & 28,7 & 28,4 & $-3,7$ \\
\hline Будівництво & 12,6 & 12,0 & 12,9 & 12,6 & 0,0 \\
\hline $\begin{array}{l}\text { Оптова та роздрібна торгівля; ремонт } \\
\text { автотранспортних засобів і мотоциклів }\end{array}$ & 95,1 & 96,6 & 95,3 & 94,5 & $-0,6$ \\
\hline $\begin{array}{l}\text { Транспорт, складське господарство, } \\
\text { поштова та кур'єрська діяльність }\end{array}$ & 21,4 & 21,3 & 23,0 & 22,7 & $+1,3$ \\
\hline $\begin{array}{l}\text { Тимчасове розміщування й організація } \\
\text { харчування }\end{array}$ & 6,9 & 6,7 & 6,3 & 5,8 & $-1,1$ \\
\hline Інформація та телекомунікації & 3,7 & 3,6 & 3,3 & 3,4 & $-0,3$ \\
\hline Фінансова та страхова діяльність & 4,3 & 3,9 & 3,7 & 3,6 & $-0,7$ \\
\hline Операції з нерухомим майном & 5,9 & 5,9 & 6,0 & 5,9 & 0,0 \\
\hline $\begin{array}{l}\text { Професійна, наукова та технічна } \\
\text { діяльність }\end{array}$ & 8,1 & 8,4 & 7,3 & 7,4 & $-0,7$ \\
\hline $\begin{array}{l}\text { Діяльність у сфері адміністративного та } \\
\text { допоміжного обслуговування }\end{array}$ & 4,4 & 4,3 & 4,2 & 3,3 & $-1,1$ \\
\hline $\begin{array}{l}\text { Державне управління й оборона; } \\
\text { обов’язкове соціальне страхування }\end{array}$ & $26,2^{1}$ & 26,3 & 27,2 & 29,1 & $+2,9$ \\
\hline Освіта & 42,1 & 44,5 & 39,4 & 37,9 & $-4,2$ \\
\hline $\begin{array}{l}\text { Охорона здоров'я та надання соціальної } \\
\text { допомоги }\end{array}$ & 27,1 & 26,0 & 25,7 & 25,1 & $-2,0$ \\
\hline Мистецтво, спорт, розваги та відпочинок & 8,3 & 8,2 & 7,7 & 7,7 & $-0,6$ \\
\hline Інші види економічної діяльності & 8,2 & 8,4 & 8,9 & 8,7 & $+0,5$ \\
\hline
\end{tabular}

Ажерело: розраховано за даними [5]. 


\section{Таблиця 4. Рівень зайнятості населення за статтю та місцем проживання, за віковими групами у 2017 році (відсотків до кількості всього населення відповідної вікової групи)}

\begin{tabular}{|l|l|l|l|l|l|l|l|l|}
\hline & \multirow{2}{*}{$\begin{array}{c}\text { Усього } \\
\text { у віці }\end{array}$} & \multicolumn{6}{|c|}{ у тому числі за віковими групами (років) } \\
\cline { 5 - 10 } & $15-70$ років & $15-24$ & $25-29$ & $30-34$ & $35-39$ & $40-49$ & $50-59$ & $60-70$ \\
\hline Усе населення & 56,2 & 35,4 & 68,3 & 68,4 & 80,0 & 78,5 & 67,6 & 6,8 \\
\hline жінки & 48,2 & 24,8 & 56,7 & 56,9 & 75,1 & 74,2 & 60,5 & 4,6 \\
\hline чоловіки & 65,0 & 45,3 & 79,3 & 79,5 & 85,0 & 83,2 & 76,3 & 10,0 \\
\hline міські поселення & 52,7 & 29,5 & 66,7 & 63,5 & 76,7 & 74,0 & 63,8 & 6,1 \\
\hline $\begin{array}{l}\text { сільська } \\
\text { місцевість }\end{array}$ & 61,7 & 42,9 & 70,7 & 77,5 & 85,4 & 85,5 & 73,7 & 8,0 \\
\hline
\end{tabular}

Ажерело: розраховано за даними [5].

часних умовах економічної нестабільності, дослідити причини негативних тенденцій, визначення можливих напрямів переходу до продуктивної та інноваційної зайнятості.

\section{ВИКЛАД ОСНОВНОГО МАТЕРІАЛУ}

У зв'язку з кризовими явищами, які почалися у 2014 році у політиці та економіці, ринок праці України зазнав несприятливої трансформації. Соціально-економічна нестабільність і гальмування економічного зростання призвели до істотного охолодження ринку праці. Сучасний ринок праці має низку досить значущих для життя суспільства проблем: відсутність мотивації в професійній сфері, низький рівень оплати праці та соціальної допомоги, високий рівень безробіття, постійне скорочення робочих місць у зв'язку несприятливими економічними обставинами, невідповідність професійної структури зайнятих професійній структурі робочих місць. Що стосується ринку праці Херсонської області, можна спостерігати суттєві структурні зрушення у сфері зайнятості. При цьому їх не можна охарактеризувати як позитивні та такі, що розвиваються у відповідності до сучасних тенденцій НТП.

Розглянемо ключові тенденції у трансформації зайнятості населення Херсонської області. У таблиці 1 відображена структуру зайнятого населення.

Так, за період 2014-2017 рр. кількість зайнятого населення скоротилась на 8 тис. осіб віком $15-70$ років та на 1.3 тис. осіб працездатного віку. Рівень зайнятості працездатного населення України у 2017 році становив $64,5 \%$, у Херсонської області цей показник дещо кращий $-66,3 \%$.

У Херсонської області відбулося зростання безробітного населення у 2017 році на 5,4 тис. осіб порівняно з 2014 р., в основному за рахунок високого зростання безробіття у період 3 2015 по 2016 рр. (на 5,1 тис. осіб).

Стабільний розвиток економіки регіону неможливий без достатнього функціонування економік окремих галузей або видів економічної діяльності. Варто відзначити, що інтенсивніший розвиток одних галузей обумовлює і розвиток інших видів діяльності. Такі провідні галузі підвищують рівень розвитку регіону та стабілізують його економічну систему.

Проте для такого зростання важливий розвиток кадрових ресурсів, адже саме від наявності висококваліфікованих працівників належатиме функціонування підприємств. Водночас структура зайнятості формується разом із створенням нових видів економічної діяльності, реформуванням сільського господарства та промисловості. При цьому важливим $€$ інноваційний вектор розвитку, який надасть можливість створення нових робочих місць відповідно до потреб інноваційних зрушень в економіці. У зв'язку із набранням чинності з 1 січня 2012 року національного класифікатора України АК 009:2010 " Класифікація видів економічної діяльності" (KBEA-2010) стає можливим проведення оцінки структурних зрушень в зайнятості за видами економічної діяльності за 2014-2017 рр. (табл. 3).

Так, значні структурні зрушення відбулися за усіма видами економічної діяльності. Зокрема, чисельність зайнятих скоротилась за усіма видами економічної діяльності (на 8 тис. осіб в області), скорочення структурних показників зайнятості відбулось за такими видами економічної діяльності: промисловість - 11,3\%; добувна промисловість і розроблення кар'єрів $50 \%$; переробна промисловість - $12,3 \%$; оптова та роздрібна торгівля; ремонт автотранспортних засобів і мотоциклів - 0,6\%; тимчасове розміщування й організація харчування $-16 \%$; інформація та телекомунікації - 8,1\%; фінансова та страхова діяльність - 16,3\%; професійна, наукова та технічна діяльність - 8,6\%; діяльність у сфері адміністративного та допоміжного обслуговування - $25 \%$; освіта $-10 \%$; охорона здоров'я та надання соціальної допомоги - 7,4\%; мистецтво, спорт, розваги та відпочинок - 7,2\%. 


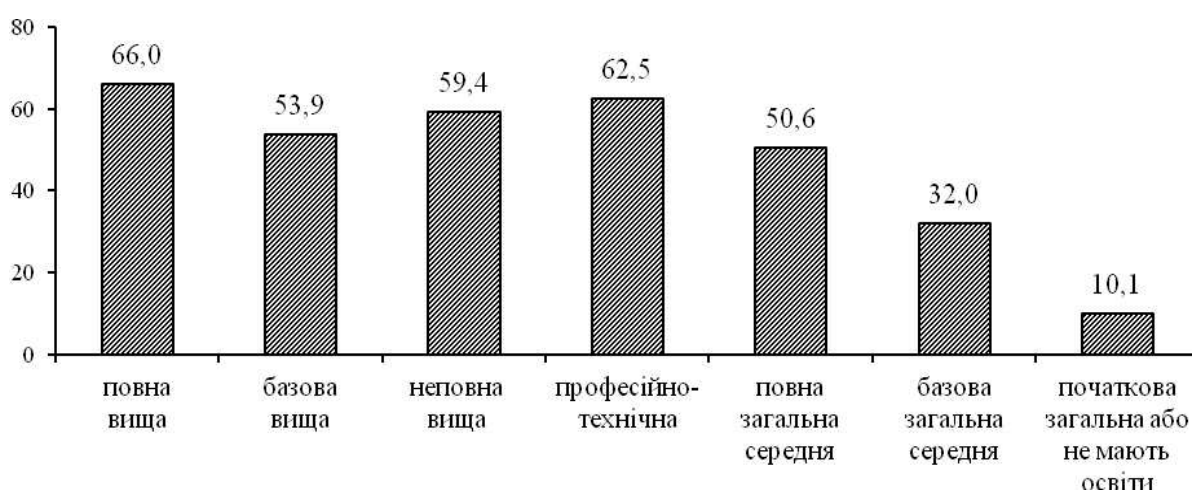

Рис. 1. Рівень зайнятості населення Херсонської області за освітою у \% до населення відповідного рівня освіти у 2017 р.

Незначне зростання структурних показників зайнятості Херсонської області спостерігалося в таких галузях: сільське, лісове та рибне господарство - 2,7\%; транспорт, складське господарство, поштова та кур'єрська діяльність - 6,1\%; державне управління й оборона; обов'язкове соціальне страхування $11,1 \%$; інші види економічної діяльності - $6,1 \%$.

Більш менш стабільними виявилися показники зайнятості у будівництві та за таким ви- дом економічної діяльності, як операції з нерухомим майном.

Таким чином, можна стверджувати, що структурні зміни зайнятості населення є деструктивними, оскільки скорочення зайнятих відбуваються в інформаційній та телекомунікаційній сферах, а також у сферах обслуговування самої людини.

Отже, тенденція підвищення показника зайнятості у сфері послуг обумовлена не зростан-

Таблиця 5. Попит та пропозиція робочої сили Херсонської області за професійними групами у $2014-2017$ рр., осіб

\begin{tabular}{|c|c|c|c|c|c|c|c|c|c|c|}
\hline \multirow[b]{2}{*}{ Професійні групи } & \multicolumn{5}{|c|}{ Кількість зареєстрованих безробітних } & \multicolumn{5}{|c|}{$\begin{array}{c}\text { Потреба роботодавців у працівниках для заміщення } \\
\text { вільних робочих місць (вакантних посад) }\end{array}$} \\
\hline & 2014 p. & $2015 \mathrm{p}$. & $2016 \mathrm{p}$. & 2017 p. & 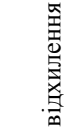 & 2014 p. & $2015 \mathrm{p}$. & $2016 \mathrm{p}$. & 2017 p. & 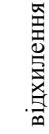 \\
\hline $\begin{array}{l}\text { Законодавці, вищі } \\
\text { державні службовці, } \\
\text { керівники, } \\
\text { менеджери } \\
\text { (управителі) }\end{array}$ & 1282 & 1616 & 1367 & 1181 & -101 & 55 & 30 & 33 & 39 & -16 \\
\hline Професіонали & 1090 & 1057 & 805 & 768 & -322 & 142 & 93 & 59 & 83 & -59 \\
\hline Фахівці & 1363 & 1371 & 915 & 852 & -511 & 85 & 42 & 46 & 59 & -26 \\
\hline Технічні службовці & 845 & 857 & 532 & 571 & -274 & 21 & 14 & 11 & 26 & +5 \\
\hline $\begin{array}{l}\text { Працівники сфери } \\
\text { торгівлі та послуг } \\
\end{array}$ & 2448 & 2440 & 1654 & 1706 & -742 & 57 & 70 & 50 & 91 & +34 \\
\hline $\begin{array}{l}\text { Кваліфіковані } \\
\text { робітники сільського } \\
\text { та лісового } \\
\text { господарств, } \\
\text { риборозведення та } \\
\text { рибальства }\end{array}$ & 1665 & 1814 & 1394 & 1296 & -369 & 2 & 14 & 12 & 8 & +6 \\
\hline $\begin{array}{l}\text { Кваліфіковані } \\
\text { робітники } 3 \\
\text { інструментом }\end{array}$ & 1227 & 1068 & 665 & 708 & -519 & 64 & 45 & 74 & 47 & -17 \\
\hline $\begin{array}{l}\text { Робітники з } \\
\text { обслуговування, } \\
\text { експлуатації та } \\
\text { контролюванню за } \\
\text { роботою } \\
\text { технологічного } \\
\text { устаткування, } \\
\text { складання } \\
\text { устаткування та } \\
\text { машин }\end{array}$ & 2414 & 2246 & 1929 & 2145 & -269 & 86 & 63 & 65 & 49 & -37 \\
\hline Найпростіші професії & 2766 & 2758 & 1939 & 1996 & -770 & 42 & 70 & 52 & 74 & +32 \\
\hline Усього & 15100 & 15227 & 11200 & 11223 & -3877 & 554 & 441 & 402 & 476 & -78 \\
\hline
\end{tabular}

Ажерело: розраховано за даними [5]. 
ням кількості працюючих в інформаційній сфері, а незначним підвищенням структурного показника зайнятості у транспорті, складському господарстві, поштової та кур'єрської діяльності.

В останнє десятиріччя сегрегація зайнятості за видами економічної діяльності набула істотних змін, а саме:

- розширились види та форми зайнятості: аутсорсінг, фріланс, віддалена зайнятість тощо;

- розширилась сфера послуг фінансової та страхової діяльності, інформації та телекомунікації тощо за рахунок зменшення сфери матеріального виробництва, що $є$ важливим кроком до розвитку інноваційної праці;

- з'явилися нові компетенції, які є необхідними для нових професій та для сучасних умов праці: обов'язковими стають навички роботи за комп'ютером, багато професій потребують знання іноземних мов, уміння спілкуватися 3 людьми, домовлятися і керувати ними, вміння вести бізнес тощо;

- значно розширився сектор таких наукомістких видів діяльності, як інформаційні, наукові, технічні, консалтингові, юридичні тощо, але він розвивається достатньо повільно і не має вирішального впливу на прискорення інноваційних процесів та удосконалення виробництва.

Рівень зайнятості населення Херсонської області станом на 1 січня 2018 року становив $56,2 \%$, зайнятість серед чоловіків на 16,8 \% вища ніж у жінок. Але, як доведено багатьма фахівцями 3 гендерних проблем, очевидним $€$ той факт, що безробітні жінки є більш проблемною групою, оскільки втрата роботи для них пов'язана з меншою імовірністю виходу зі стану безробіття, порівняно з чоловіками. Проте аналіз загальних показників зайнятості й безробіття та їх гендерний розподіл засвідчує, що в Україні для жінок існують доволі широкі можливості зайнятості, і в динаміці ці можливості зростають 6. Рівень зайнятості населення, що проживає у сільської місцевості вища на 9\% ніж у міських поселеннях, що зумовлено сезонністю сільськогосподарської праці і, як наслідок, переміщенням значної кількості міського працездатного населення у сільську місцевість в пошуках роботи. (табл. 4).

Аинаміка рівня зайнятості населення Херсонської області за різними віковими групами показує, що вікові групи $35-39$ років та $40-49$ мають майже однакові значення рівня зайнятості, близькою до них є динаміка у вікової групі 30-34 років. Аостатньо високі значення рівня зайнятості має ще одна група людей 50-59 років, бо згідно із Законом України "Про заходи щодо законодавчого забезпечення реформування пенсійної системи" та із Законом України "Про внесення змін до деяких законодавчих актів України щодо підвищення пенсій" чоловіки (а тепер ще й жінки) цієї вікової категорії належать до працездатного віку. Це позитивно вплинуло на рівень зайнятості цієї вікової групи.

Показники рівня зайнятості за ступенями освіти демонструють, що працівники з вищою освітою $є$ достатньо затребуваними на ринку праці (рис. 1).

Рівень зайнятості у 2017 р. склав 66,0 \% для людей із повною вищою освітою, для людей, що мають неповну вищу освіту $-59,4 \%$ та базову вищу- 53,9\%. Працівники 3 професійно-технічною освітою також користуються попитом у роботодавців, рівень зайнятості складає $62,5 \%$. Найменш затребуваними залишаються люди з початковою загальною або ті, які зовсім не мають освіти - $10,1 \%$.

Важливе значення під час дослідження структурних зрушень зайнятості має оцінка професійно-кваліфікаційної структури зайнятості населення Херсонської області та змін їі динаміки (табл. 5).

Так, за період 2014-2017 рр. кількість зареєстрованих безробітних за професійними групами скоротилася на 3877 осіб, що є досить низьким показником ефективних структурних зрушень зайнятості, поряд з цим скоротилась потреба підприємств Херсонської області у працівниках для заміщення вільних робочих місць (вакантних посад). Значне зниження попиту відбулося на робочу силу таких професійно-кваліфікаційних груп: професіонали $58,5 \%$, фахівці - $69,4 \%$, робітники з обслуговування, експлуатації та контролювання за роботою технологічного устаткування - $60 \%$. Підвищився попит з боку роботодавців на: технічних службовців - 23,8\%, кваліфікованих робітників сільського та лісового господарств, риборозведення та рибальства - у 4 рази, найпростіших професій - 76,2\%. Варто вказати також на значне зростання попиту на працівників сфери торгівлі та послуг $(59,6 \%)$, але часто ця сфера не потребує висококваліфікованих працівників, плинність кадрів дуже висока, тому коливання у попиту та пропозиції робочої сили завжди значні.

Незважаючи на достатньо високий зріст кількості висококваліфікованих працівників у складі зайнятого населення, частка працівників із низькою кваліфікацією залишається досить 
великою, що призводить до гальмування інноваційного розвитку сфери зайнятості [7, с. 60], бо інноваційна зайнятість передбачає необхідність отримання працівником нових знань упродовж всього життя [8, с. 274].

\section{ВИСНОВКИ}

Проаналізувавши наявні статистичні дані, можна стверджувати, що структура зайнятості в Херсонській області є протилежною високорозвинутим країнам, оскільки більша частина трудового потенціалу, порівняно з іншими галузями, припадає на галузі матеріального виробництва. Спостерігається досить низький рівень зайнятості сфер обслуговування самої людини: освіти, охорони здоров'я, науки, соціального забезпечення та інших. Аля трансформації структури зайнятості важливого значення набуває зростання галузей обслуговування. При цьому відбувається не тільки диверсифікація системи галузей та видів діяльності, але й з'являються нові процеси обслуговування; та частина обслуговуючих функцій, яка раніше входила до складу сільського господарства чи промисловості, відокремиться в незалежні галузі обслуговування, що існуватимуть самостійно. Структурні зміни, що відбуваються сьогодні в економіці, повинні забезпечити вихід із стану рецесії, тотального обвалу виробництва та масового безробіття.

У такій ситуації реформування економіки мають спрямовуватися на активізацію соціально-економічного розвитку, підтримку та прогрес інноваційно-технологічної діяльності, стабілізації ситуації на ринку праці. Разом з тим недостатня увага до розвитку інтелектуалізації, наукомісткості праці, впровадження нових технологій у перспективі може стати гальмуючим фактором впливу на соціально-економічний розвиток.

$\Lambda$ ітература:

1. Онікієнко В.В. Розвиток ринку праці України: тенденції та перспективи: монографія / В.В. Онікієнко, М.М. Емельяненко, А.Г. Ткаченко. - К.: РВПС України НАН України, 2007. 286 c.

2. Маршавін Ю.М. Регулювання ринку праці України: теорія і практика системного підходу: монографія / Ю.М. Маршавін. - К.: Альтерпрес, 2011. - 396 с.

3. Чернявська Ю.Б. Економічні важелі механізму державного регулювання ринку праці в Україні / Ю.Б. Чернявська // Формування ринкових відносин в Україні. — 2007. - 8 (75). - C. $104-105$.
4. Системна криза в Україні: передумови, ризики, шляхи подолання: аналіт. доп./ Я.А. Жаліло, К.А. Кононенко, В.М. Яблонський та ін.; за заг. Ред. Я.А. Жаліла. - К.: НICA, 2014. $132 \mathrm{c}$.

5. Статистичний щорічник Херсонської області за 2017 рік / За ред. В.А. Вознюка. - Херсон: Головне управління статистики у Херсонській області. 2018. - 452 с.

6. Сергій О. Гендерний аспект ринку праці України / О. Сергій, А. Рандіна // Управління трудовими ресурсами. - 2010. - 5. - С. 3536.

7. Близнюк В.В. Український ринок праці: історичні виклики та нові завдання. Український соціум. - 2016. - 3 (58). - С. 58-71.

8. Інноваційна Україна 2020: національна доповідь / за заг. ред. В. Гейця та ін.; НАН України. - Київ, 2015. - 336 с.

\section{References:}

1.Onikiinko,V.V. Yemelianenko, L.M. and Tkachenko, L.H. (2007), Rozvytok rynku pratsi Ukrainy: tendentsii ta perspektyvy Development of the Ukrainian labor market: trends and prospects , RVPS Ukrainy NAN Ukrainy, Kyiv, Ukraine, p. 286.

2. Marshavin, Yu. M. (2011), Rehuliuvannia rynku pratsi Ukrainy: teoriia I praktyka systemnoho pidkhodu Development of the Ukrainian labor market: trends and prospects, Alterpres, Kyiv, Ukraine, p. 286.

3. Cherniavska, Yu. B. (2007), "Economic levers of the mechanism of state regulation of the labor market in Ukraine", Formuvannia rynkovykh vidnosyn v Ukraini, vol. 8 (75), pp. 104-105.

4. Zhalilo, Ya. A. and others (2014), Systemna kryza v Ukraini: peredumovy, ryzyky, shliakhy podolannia Systemic crisis in Ukraine: preconditions, risk, ways of overcoming , NISD, Kyiv, Ukraine, p. 132.

5. Vozniuk, V.A. (2017), Statystychnyj schorichnyk Khersons'koi oblasti za 2017 rik Statistikal Yearbook of Kherson Oblast for 2017 , Holovne upravlinnia statystyky u Khersons'kij oblasti, Kherson, Ukraine.

6. Serhii, O. and Randina, A. (2010), "Gender aspect of the labor market of Ukraine", Upravlinnia trudovymy resursamy, vol. 5, pp. 3536.

7. Blizniuk, V.V. (2016), "Labor market of Ukraine: historical challenges and new tasks". Ukrains'kiy sotsium. 3.(58). pp. 58-71.

8. Geits, V. (2015), " Innovative Ukraine 2020: national report". NAN, Kyiv, Ukraine.

Cтаття надійшла до редакчї 04.05.2019 p. 
УAK 338.242

\author{
М. Б. Артеменко, \\ к. е. н., Аоцент кафедри економіки та фінансів,
}

Тернопільський національний технічний університет імені Івана Пулюя, м. Тернопіль

ORCID ID: 0000-0001-6653-3043

DOI: $10.32702 / 2306-6792.2019 .9 .46$

\title{
ЄВРОПЕЙСЬКИЙ АОСВІА АЕРЖАВНОЇ ПІАТРИМКИ ОРГАНІЧНОГО ВИРОБНИЦТВА У КОНТЕКСТІ ЗАБЕЗПЕЧЕННЯ ПРОАОВОАЬЧОЇ БЕЗПЕКИ УКРАЇНИ
}

\author{
L. Artemenko, \\ Ph.D. in Economics, Associate Professor of the Department of Economics and finance, \\ Ternopil Ivan Pul'uj National Technical, University, Ternopil
}

\author{
EUVROPIEN EXPERIENCE OF GOVERNMENT SUPPORT OF THE ORGANIC PRODUCTION \\ IN THE CONTEXT OF ENSURING FOOD SECURITY OF UKRAINE
}

У статті розглянуто динамічні світові тенденції розвитку органічного продовольчого ринку. Підкреслено, що успішний досвід провідних країн має прикладне значення для сприяння системності процесу господарювання вітчизняних суб'єктів органічної сфери. Ринок сільськогосподарської органіки виступає як функціональна підсистема забезпечення продовольчої безпеки держави. Тому основна увага приділена розгляду методів державного регулювання, які використовуються в європейських країнах з метою активізації перспективного напряму агропродовольчого національного ринку. Виокремлено переваги споживання органічної продукції для здоров'я людини 3 точки зору біологічної цінності та корисності. Проаналізовано нинішній стан та надано рекомендації щодо аАаптації органічного сектору України до євроінтеграційної моделі. Визначено проблемні аспекти, які стримують вітчизняний споживчий попит на здорову продукцію. Зазначено, що їх вирішення лежить у площині державної політики. Наголошено на тому, що у ході трансформаційних процесів традиційного фермерства в органічні практики в суспільстві створюються умови балансу екологічних потреб та безпечного продовольства. Аилема ринку органіки полягає у тому, що, 3 одного боку, економіка спроможна виробити потрібну кількість продуктів високої якості, а з іншого - споживачі не в змозі забезпечити попит на такі товари. Усунути протиріччя можна тільки шляхом впровадження державних інструментів компенсаційного та мотиваційного напряму з одночасним підвищенням рівня оплати праці, що змінить вектор у бік розвитку як попиту, так і пропозиції. Ефективність розширення меж органічної сфери стане каталізатором мультиплікативного ефекту забезпечення населення якісними та екобезпечними сертифікованими продуктами харчування без шкоди довкілдю та підвищить рівень продоводьчої безпеки.

Author reviews dynamic global trends of the organic food market. Special emphasis is made on successful experience of leading states that has practical application for systematic management of domestic organic food manufacturers. Market of agro organics is a functional unit that provides food safety of the country. Thus, key attention is paid to learning of the methods of government regulations that are implemented in European countries to activate promising sectors of national agro-product market. Author distinguishes benefits for consumption of organic produce for person's health and well-being from perspective of biological value and usefulness. Author analyzed current situation and suggested recommendations to adapt organic sector of Ukraine to European integration model. Problematic aspects have been determined that slow down domestic consumer demand for healthy products and estimated that these can be solved with proper government policies. Author stressed that transformational processes of traditional farming into organic practices create conditions for balance of ecological needs and safe production. Major dilemma of the organic market is that economy is able to produce required quantity of high-quality food products. On the other hand, consumers are not able to deliver demand on such products. These contradictions may only be solved by introduction of government compensatory and motivational instruments simultaneously with increase of salary level in the industry. This will shift the industry into improving both supply and demand. Efficiency of organic industry broadening will trigger multiplicative effect in providing consumers with quality and eco-safe certified food products without harming environment that will finally increase level of food safety. Organic production in 21 st century became a contemporary trend and is considered 
to be perfect model for steady development that harmonizes its three components: economic efficiency (increasing of product competitiveness, decrease of production expense by banning chemical ingredients), ecological orientation (restoration of agricultural systems - regeneration of soil fertility, decrease of water and air pollution) and social aspect (formation of company eco-image, increasing of vitality for rural communities, providing consumers with quality food products).

Ключові слова: органічне сільськогосподарське виробничтво, державне регулювання, мотивачія, продовольча безпека, сертифікачія.

Key words: organic agricultural production, government regulation, motivation, food safety, certification.

\section{ПОСТАНОВКА ПРОБЛЕМИ}

Органічне виробництво у XXI ст. стало сучасним напрямом розвитку ресурсного світового потенціалу, модним трендом та розглядається в якості взірцевої моделі сталого розвитку, що узгоджує три його компоненти економічну ефективність (підвищення конкурентоспроможності продукції, зниження виробничих витрат внаслідок відмові від застосування хімікатів), екологічну спрямованість (відновлення агроекосистем - відтворення родючості грунтів, зниження забруднення водних джерел і атмосферного повітря) та соціальний аспект (створення екоіміджу підприємства, підвищення життєздатності сільських громад, забезпечення споживачів якісними продуктами харчування). Саме змістове наповнення продовольчої безпеки органічної продукції в повній мірі композиціонується із категорією "якість", насамперед з точки зору підвищення безпеки життя населення. Отже, набувають актуальності питання формування стратегії розвитку органічного виробництва як важливого сегмента національного аграрнопродовольчого ринку.

\section{АНАЛІЗ ОСТАННІХ ДОСЛІДЖЕНЬ І ПУБЛІКАЦІЙ}

Вітчизняна наукова думка забезпечила вагомий внесок у проблематику органічного виробництва, де серед авторів Т. Аверіхіна, В. Артиш, Ю. Бєлінська, Р. Безус, А. Гринів, Є. Каблучка, А. Сава, В. Ткачук, Т. Чайка, І. ЧичкалоКондрацька та ін. Проте деякі аспекти залишаються не у повному обсязі вирішеними. Зокрема недостатньо висвітлено підходи щодо використання європейських практик державного регулювання та стимулювання внутрішнього попиту органічної продукції з метою гарантування споживачам високої біологічно цінної якості та оздоровчих властивостей продукції, яка маркована як органічна. В умовах глобалі- заційних процесів та враховуючи перспективність вектору розвитку такої ніші економіки України, набувають пріоритетності питання використання міжнародного досвіду для запровадження нової моделі національної державної політики, спрямованої на мотивування суб'єктів господарювання органічної сфери.

\section{ФОРМУВАННЯ ЦІЛЕЙ СТАТТІ}

Метою статті $€$ констатація необхідності імплементації європейського досвіду розвитку органічного агровиробництва у вітчизняну економіку, оскільки він становить практичний інтеpec, як більш досвідчений, тривалий та успішний. Використання зарубіжних напрацювань надасть можливість державі розробити алгоритм подальших дій, які повинні охопити економіку, соціальну політику, екологію та сформулювати основні стандарти забезпечення продовольчої безпеки у відповідності до міжнародних норм та правил.

\section{ВИКЛАД ОСНОВНОГО МАТЕРІАЛУ}

Багаторічний досвід провідних європейських країн, які інтегрували органічне сільське господарство у свою аграрну політику, демонструє його лідерські позиції у забезпеченні продовольчої безпеки, що свідчить про доцільність запровадження такої концепції у вітчизняну економіку.

У XX ст. японський філософ Мокіхі Окада започаткував термін "природнє сільське господарство" (Nature Farming), де окреслив принципи, які тотожні сучасним вимогам. У 1940 році науковець Оксфордського університету лорд Нортборн вперше використав термін "органічне сільське господарство", що призвело до появи нового самостійного напряму. Піонером органічного сектору вважається Німеччина, де батько й син Георг і Клаус Хіпп у 50-х роках минулого століття свою підприємницьку діяльність сконцентрували на продуктах дитя- 


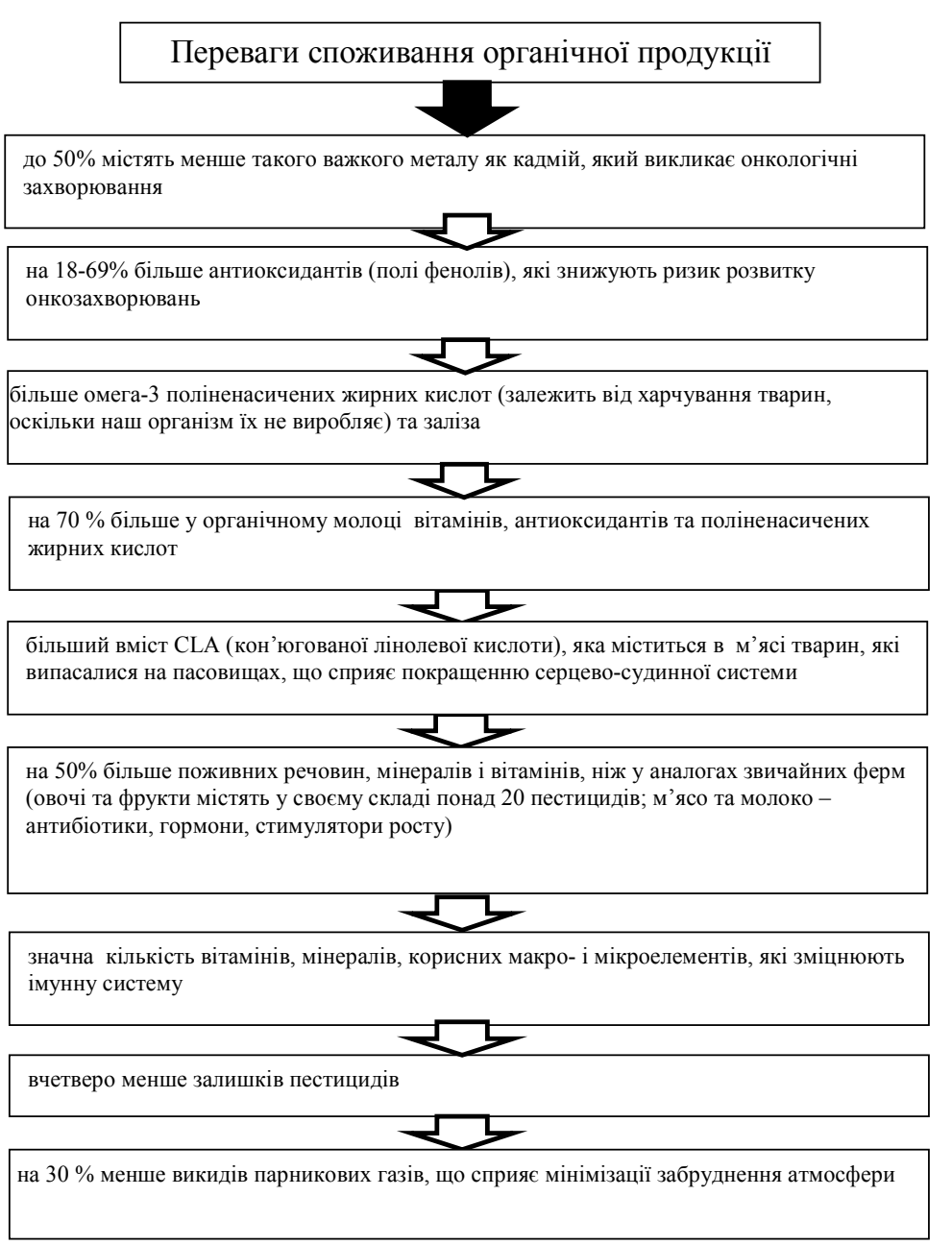

\section{Рис. 1. Переваги споживання органічної продукції} для здоров'я людини

Ажерело: сформовано за даними [3; 4].

чого харчування під брендом "НіPP". I тільки в 2008 році Міжнародною Федерацією органічного сільськогосподарського руху (IFOAM) було прийнято уніфіковане трактування органічного сільського господарства, де підкреслюється обов'язковість поєднання в собі традицій, нововведень, науки з метою покращення стану навколишнього середовища та сприяння належному рівню життя [1]. Тобто у міжнародному науковому співтоваристві $€$ усвідомлення того, що в ракурсі органічного виробництво створюються умови для забезпечення інтегрованої сталості у відповідності до концепції збалансованого розвитку.

Чим викликана така велика увага та посилений інтерес до споживання органічної продукції саме у європейських країнах? Аинамічний процес пояснюється тим що, по-перше, виробництво спирається на наявність як ресурсної бази, так і вагомих стимулів для розвитку такого ринку. Тут зосереджено $23 \%$ усіх органічних світових сільськогосподарських земель, що підтверджується відповідними сертифікатами. Чотири країни понад 10\% таких земель задіяли під органічне виробництво: Аіхтенштейн $(30 \%)$, Австрія $(16 \%)$, Швейцарія $(11,1 \%)$ та Швеція $(10,8 \%)$. Найбільші площі земель знаходяться в Іспанії (1,1 млн га) та Італії (1 млн га). Мідером за кількістю підприємств, які займаються виробництвом органічної продукції, є Італія (понад 44 тис. виробників), найбільша частка відповідного виробництва припадає на Швейцарію (35\% ринку продуктів харчування) [2]. По-друге, у країнах пропагується концепція здорового способу харчування населення, посилюється турбота урядів, яка спрямована на покращення здоров'я нації та продовження тривалості життя, фінансово спроможні споживачі стають вимогливішими та прагнуть забезпечення гарантій чистоти продуктів. I, як результат значна кількість громадян таке харчування перетворило на своєрідну "філософії життя" під гаслом: "Я живу органічно". Аослідження зарубіжних експертів засвідчили підвищену біологічну цінність та корисність споживання органічної продукції для людини у порівнянні з конвенційними товарами.

По-третє, найголовніше, спільним для європейських країн $є$ комплексне застосування різнопланової державної фінансової підтримки виробників органічної продукції. Програми, які стосуються органічного землеробства, а значить і підтримки екології, не підпадають під обмеження з боку бюджетного фінансування у відповідності до принципів СОТ.

Провідним іноземним досвідом слугують Нідерланди, де фермери, торговці, банки та переробники знайшли збалансоване узгоджене рішення з метою збільшення частки як місцевого ринку органічних продуктів, так і його експорту. Уряд країни витратив 50 млн євро упродовж 2008-2011 рр. на інновації та інформованість населення, в результаті чого експорт такої продукції збільшився до 50\% [5, с. 44]. Франція стала першою країною Європейського Союзу, яка впровадила механізм підтримки органічного сільського господарства в 1993 році. В сучасних умовах фермерам надаються податкові кредити у сумі 2500 євро на рік, при потребі можливо отримати додаткові кошти в розмірі 400 євро на гектар. Аеякі регіони країни використовують інші преференції (наприклад, у 
Пікардії господарствам, які повністю перейшли на органічне виробництво, компенсується $100 \%$ витрат та 50\% для тих, які частково здійснили такі заходи [5, с. 52]. Швейцарія, де був заснований у 1973 році дослідний інститут органічного сільського господарства (FiBL), має найвищий у світі показник споживання органічної продукції на душу населення 274 євро на рік [6], що є прикладом успішної державної мотиваційної політики власного виробника. Країна представляє свою корисну органічну продукцією під брендом "Naturaplan" з логотипом зеленого серця. Це засвідчує вдалу маркетингову політику та підкреслює гармонізацію інтересів всіх учасників ринку: споживачів, виробників та суспільства. На особливу увагу заслуговує практика державного стимулювання Польщі, яка здійснюється за кількома напрямами: дотується участь фермерів у системах контролю якості харчових продуктів (додатковий дохід у 255 євро на рік); виділяється допомога на рекламну та інформаційну діяльність (до 70\% таких витрат); компенсуються витрати, пов'язані з переходом до виробництва органіки (в середньому 240 євро за 1 га на рік) [7]. Уряд Чехії щорічно у вересні проводить конкурс "Місяць органічних харчових продуктів", обов'язковим є закупівля дошкільними, освітніми та медичними закладами не менше $70 \%$ органічних продуктів. Аналогічний підхід використовується також в Італії та Аанії для шкільного харчування, а Голландія заохочує виїзне органічне ресторанне обслуговування (кейтерінг).

У сучасному тренді споживачів Европи, після буму органічної продукції, з'явилися нові вимоги до продукції під маркуванням "органік +", що означає: без солі (або із мінімальним їі вмістом), без глютену, з високим вмістом клітковини та протеїну, попит на корисні суперфуди. Прикладом довготривалого позиціювання таких продуктів може слугувати досвід Великої Британії, яка пропагує здорове харчування через інформаційні канали, які закликають споживачів стежити за кількістю солі та цукру в продуктах харчування, споживати протягом дня п'ять різноманітних овочів та фруктів. На такі заходи уряд щорічно виділяє 1 млрд фунтів стерлінгів [8, c. 103].

Отже, із вище зазначеного, можна зробити висновок про тісний взаємозв'язок рівня розвитку органічного виробництва від розміру державної підтримки як запоруки зміцнення продовольчої безпеки та здоров'я населення. Комплексна та дієва державна підтримка вироб- ників органіки в Европі здійснюється за різними напрямами та за допомогою низки інструментів, які можна згрупувати:

1. Використання фінансових важелів підтримки органічного сільського господарства (надання субсидій в рамках національних або регіональних програм з метою компенсації додаткових витрат під час конверсійного періоду, отримання дотацій протягом трьох років перехідного періоду, пільги з оподаткування та кредитування, покриття частини або у повному обсязі витрат на сертифікацію).

2. Впровадження програм підтримки органічного тваринництва, спрямованих на відшкодування додаткових витрат у зв'язку із зобов'язаннями фермерів випасати худобу на відкритому повітрі.

3. Грантове фінансування (для молодих підприємців на інноваційні проекти, модернізацію сільськогосподарських угідь, придбання біообладнання).

4. Інформаційна підтримка (проведення науково-популярної реклами, спеціалізованих виставок, ярмарок; надання фахових консалтингових консультації конверсії органічного господарства; забезпечення професійної підготовки, освітніх та кулінарних курсів для учнів навчальних закладів, екскурсій на такі ферми).

5. Розповсюдження системи безпосередньої доставки екопродуктів від виробників до споживачів (абонементні кошики, тобто заходи пабліситі з використанням Інтернету та преси, постачання екопродуктів до шкільних їдалень та закладів: медичних, курортних, громадського харчування).

6. Адресна державна допомога: екологічним інспекціям, науковим організаціям, які досліджують екологічні насіннєві та тваринницькі питання; для підвищення кваліфікації фермерів.

7. Налагоджена гарантійна система якості органічного сільського господарства (сертифікація, акредитація, встановлення стандартів, інспектування, маркування).

Аграрний сектор України є традиційною галуззю спеціалізації України та завжди розглядався як один із локомотивів розвитку національної економіки. Україна посідає 11-е місце в Европі за обсягами виробництва органічних продуктів, тому перехід на органічні стандарти є одним із майбутніх векторів підвищення конкурентоспроможності аграрного сектору держави. Поки що такий ринок залишається незначним у порівнянні з європейськими країнами та в більшій мірі орієнтований на експорт (приблизно 80 \% продукції). 
Таблиця 1. Позиції України у Глобальному індексі продовольчої безпеки 3а 2012-2018 pp.

\begin{tabular}{|l|l|l|l|}
\hline Роки & $\begin{array}{c}\text { Значення } \\
(\text { бали })\end{array}$ & $\begin{array}{c}\text { Відхилення } \\
(+/-)\end{array}$ & $\begin{array}{c}\text { Позиція у } \\
\text { рейтингу }\end{array}$ \\
\hline 2012 & 58,4 & & 44 \\
\hline 2013 & 58,0 & $-0,4$ & 47 \\
\hline 2014 & 58,0 & $-1,6$ & 52 \\
\hline 2015 & 56,1 & $-0,3$ & 59 \\
\hline 2016 & 55,2 & $-0,9$ & 63 \\
\hline 2017 & 54,1 & $-1,1$ & 63 \\
\hline 2018 & 55,7 & $+1,8$ & 63 \\
\hline
\end{tabular}

Ажерело: сформовано за даними [10].

Окреслимо досягнуті результати досліджуваної сфери. В Україні прийнято Закон "Про виробництво та обіг органічної сільськогосподарської продукції та сировини" та ухвалена стратегія розвитку аграрного сектору економіки на період до 2020 р., серед пріоритетних напрямів якої - забезпечення продовольчої безпеки. Позитивний момент у прийнятті таких законодавчих документів полягає у тому, що започатковується формування нормативноправової бази у цій сфері. Окрім того, передбачена державна фінансова підтримка фермерським господарствам в якості безвідсоткових кредитів обсягом до 500 тис. грн; деякі області внаслідок децентралізації почали закладати у місцеві бюджети фінансові кошти на часткову компенсацію вартості органічної сертифікації; створена система сертифікації органічної продукції, яка здійснюється спеціалізованим органом "Органік Стандарт" за міжнародними стандартами. Нарешті із 2 серпня 2019 р. набере чинності Закон України "Про основні принципи та вимоги до органічного виробництва, обігу та маркування органічної продукції", де передбачено введення єдиного державного логотипу з написом "organic", що означатиме вміст не менше ніж 95\% органічних інгредієнтів, виробники будуть внесені до нового Аержавного реєстру операторів. Використання терміну "органічне виробництво" буде стосуватися тільки сертифікованої діяльності виробництва на всіх стадіях технологічного процесу (збирання, обробка та операції, які пов'язані із зміною стану продукції). Також заборонено застосовувати пестициди, консерванти, штучні барвники, генетично модифіковані організми (ГМО). Тобто в законі сформульовані основоположні вимоги для органічного сільського господарства, відповідальність за оману споживача з боку виробників та гарантія захисту його прав. Продукція із маркерами: "еко", "біо", "натуральний" буде знята із продажу.

Важливим кроком у розширенні нових ініціативних ідей є створення достатньо розга- луженої системи різних громадських організацій, які займаються популяризацією безпечної продукції, як-от: Федерація органічного руху України, Асоціація "Біо Аан Україна", Спілка учасників органічного сільського господарства "Натурпродукт". У 2017 році створена Громадська спілка "Український органічний кластер". Аосвід кластерного підходу європейських країн засвідчує появу процесів інтеграції конкуренції та співробітництва, використання інноваційних технологій, створення нових робочих місць із замкненим циклом виробництва, що загалом забезпечує ефективність механізму регіонального розвитку. Нові можливості для розширення споживання органічної продукції відкриває проект "Органічна корзина", який стартував наприкінці 2015 року, де Тернопільська область представлена такими фірмами, як "Аисоня Біо" (молочні продукти) та "Жива земля Потутори" (травяні чаї, пряні трави та спеції).

Слід зазначити, що хоча в Україні сформована система виробництва, сертифікації та контролю органічних продуктів, діють спільні проекти із Швейцарією, Німеччиною, Австрією, внутрішнє споживання залишається на досить низькому рівні. Потенційними вітчизняними споживачами органічної продукціїє близько 5 \% населення великих та близько 1-2 \% середніх міст України. Найбільша частка припадає на м. Київ (біля $25 \%$ ), близько $10 \%$ - на обласні центри [9], сільське населення орієнтується на свої земельні ділянки.

Окрім того на протязі останніх трьох років Україна стабільно посідає "центриський" рядок рейтингу (63 місце) та останнє (26 місце в Європі) серед 133 країн світу у Глобальному індексі продовольчої безпеки (Global Food Security Index), який визначається із 2012 року 3 метою виявлення найбільш і найменш уразливих країн світу з точки зору продовольчої безпеки. Базою для формування оцінки слугують 34 параметра, але основними індикаторами є три групи факторів: фінансова та фізична доступність (affordability), достатність (availability), якість та безпечність (quality and safety). Із 2017 року методика розрахунку індексу збагатилася новим складником - природні ресурси та стійкість, визнаючи необхідність збереження ресурсів та їх адаптацію до кліматичних змін, які зумовлені процесами глобального потепління. За цим параметром наша держава посіла у 2018 році посіла 76 місце, у 2017 року - 74 [10]. Зміну позиції України у GFSI демонструє таблиця (табл. 1). 
У наведеній таблиці поточні показники $\mathrm{У}_{\mathrm{K}}$ раїни за вказаний період демонструють регресивні результати: (-19 місць) та (-2,7 балів). Експерти відзначили такі сильні сторони низький рівень втрат продовольства, показники безпеки продуктів харчування $(98,4$ бала із 100 можливих), якість та безпечність (43 місце). Слабкими позиціями країни є низький рівень ВВП на душу населення та відсутність доступу до дешевих кредитів. Отже, напрошуються висновки, що погіршення рейтингу у глобальному індексі та незначні обсяги споживання здорової органічної продукції пояснюється тим, що:

- вітчизняний інформаційний простір навпаки активно рекламує та переконує населення споживати некорисні та "нездорові" продукти такі, як чіпси, сухарики, бургери, солодощі, ковбасні вироби, солодка газована вода;

- споживацькі пріоритети громадян країни лежать у площині низького життєвого рівня. Оскільки органічна продукція передбачає збільшення цінової премії на 40-60\%, тому тільки за наявності вирішальної умови підвищення рівня оплати праці формується мотиваційний механізм внутрішнього попиту;

- унеможливлюється розвиток органічного сектору, як свідчить зарубіжний досвід, без обов'язкової дієвої фінансової державної підтримки як складової забезпечення продовольчої безпеки країни;

- стимулювати внутрішній споживчий попит необхідно шляхом проведення просвітницької PR- компанії, спрямованої на формування споживацької свідомості та суспільної обізнаності щодо переваг органічної продукції (рекламні заходи і акції, виставки, фестивалі, дегустаційні ярмарки, круглі столи) із одночасним моніторингом умов реалізації; популяризації таких торгових марок, на шталт "Родинний добробут" (органічні овочі, зелень та салати); "BIOFARM ORGANIC" (іміджева лінійка товарів під гаслом "Смачнюсики 3 користю": пасти на основі органічного меду, батончики 3 горіхами і медом, протеїнові добавки з ядрів коноплі); "Рудь"(органічне морозиво пломбір без глазурі); "Золотий Пармен" (соки, яблука).

Оскільки процеси гармонізації та адаптації законодавства у сфері органічного регулювання досить фінансово затратні (для прикладу, на старті органічного молочного тваринництва потрібно інвестувати в кожну корову 1 тисячу доларів) [11], модератором таких процесів має стати держава. Ао найважливіших заходів, які мають бути реалізовані на державному рівні в
Україні можна віднести: систему фінансової підтримки такої сфери, зокрема бюджетні субсидії (у тому числі для здійснення конвертації та сертифікації), зменшення процентних ставок за інвестиційними кредитами, пільги з оподаткування. Європейський досвід засвідчує домінантну роль субсидій підтримки ринку органічної продукції. Варто застосовувати також інші наявні інструменти та важелі державного впливу, а саме: задіяти механізм земельного моніторингу, уніфікувати нормативи оцінки якості природних ресурсів, забезпечити дієвий контроль за дотриманням фітосанітарних норм. Одна 3 провідних ролей у стратегії розвитку органічного агропродовольчого ринку відводиться внутрішній інфраструктурі, яка нині залишається слабкою ланкою, тому доцільним стане створення спеціалізованих магазинів, належних каналів логістики, дилерських фірм, сервісних центрів. Тобто ключова позиція мотиваційного процесу полягає у налагодженні усього ланцюга комунікацій - від виробника до покупця.

\section{ВИСНОВКИ}

Підводячи підсумки, можна констатувати, що основна дилема ринку органіки полягає у тому, що, з одного боку, економіка спроможна виробити потрібну кількість продуктів високої якості, а 3 іншого - споживачі не в змозі забезпечити попит на такі товари. Усунути протиріччя можна тільки шляхом впровадження державних інструментів компенсаційного та мотиваційного напряму з одночасним підвищенням рівня оплати праці, що змінить вектор у бік розвитку як попиту, так і пропозиції. Трансформація традиційного фермерства в органічні практики із врахуванням особливостей природно-ресурсного потенціалу України лежить в площині державної політики, яка створить в суспільстві умови балансу екологічних потреб та безпечного продовольства. Ми поділяємо думку $\Lambda$. Гринів, що найбільша віддача в довготерміновому періоді агроекосистема може забезпечити лише за умови органічного землеробства, оскільки тоді вона функціонує у замкнутому циклі, а відтак відбувається нарощування енергетичного бюджету природи Землі $[12$, с. 11]. Отже, ефективність розширення меж органічної сфери стане каталізатором мультиплікативного ефекту забезпечення населення якісними та екобезпечними сертифікованими продуктами харчування без шкоди довкіллю та підвищить рівень продовольчої безпеки. 


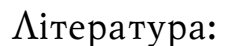

1. The official website of the International Federation of Organic Agriculture Movements. URL: www.ifoam.bio/sites/default/files/page/file s/ doa_ukranian.pdf (in Ukrainian)

2. IFOAM Basic Standards (approved by the IFOAM General Assembly, Victoria, Canada (August 2002). URL: www.ifoam.org

3. Романенко Ю. Три переваги органічних продуктів. Студвей. - 2018. URL: https://stud way.com.ua/organichni-produkti/

4. Каблучка Є. За останні півтора роки кількість органічних виробників збільшилася вдвоє. Енерго $\Lambda$ айф. інфо. - 2016. URL: http:// energolife.info/ ua/2016/News/ 2846

5. Швейцарсько-український проект: Можливості державної підтримки для розвитку органічного сільського господарства: досвід інших країн. - 2013. - 122 c. URL: ttp://www.ukraine.fibl.org/ fileadmin/documents-ukraine/

6. Чичкало-Кондрацька І.Б., Новицька I.В. Світовий досвід просування органічної продукції. Ефективна економіка. - 2018. - № 2. URL: http://www.economy.nayka.com.ua/pdf/ 2_2018/10.pdf

7. FiBL \& IFOAM The World of Organic Agriculture: statistics and Emerging Trends, Frick and Boon. - 2016. - 340 c. URL: http:// orgprints.org/31151/1/willer-lernoud-2016world-of-organic.pdf

8. Wiswall R. The Organic Farmer's Business Handbook: A Complete Guide to Managing Finances, Crops, and Staff - and Making a Profit, Chelsea: Green Publishing - Boon: Germany. 2009. - 224 c.

9. Офіційний веб-сайт Міністерства аграрної політики та продовольства України. URL: http://minagro.gov.ua/ -

10. Global Food Security Index model. Official site of The Global Food Security Index - 2018. URL: https://foodsecurityindex.eiu.com/Resources

11. Аебідь $\Lambda$. Узаконені правила для органіки. Аграрний тиждень. - 2012. URL: https:// a7d.com.ua/agropoltika/agri-work/8579-uzakonen-pravila-dlya-organki.html

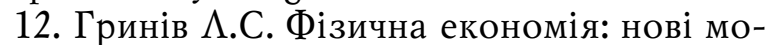
делі сталого розвитку: монографія. $-\Lambda_{\text {ьвів: }}$ Міга-прес, 2016. - 424 с.

\section{References:}

1. The official website of the International Federation of Organic Agriculture Movements, (2008), [Online], available at: www.ifoam.bio/ sites/default/files/page /file s/doa_ukranian.pdf (in Ukrainian) (Accessed 22 March 2019).
2. IFOAM "Basic Standards", approved by the IFOAM General Assembly, Victoria, Canada (August 2002), [Online], available at: www.ifoam.org (Accessed 22 March 2019).

3. Romanenko, U. (2018), "Three Advantages of Organic Products", Studway, [Online], available at: https://stud way.com.ua/organichni-produkti/ (Accessed 21 April 2019).

4. Kabluchka, E. (2016), "Number of Organic Producers Doubled During Last One and Half Years", Energolife, [Online], available at: http:// energolife.info/ ua/2016/News/2846 (Accessed 7 April 2019).

5. Swiss-Ukrainian project (2013), "Opportunities of Government Support for Development of Organic Agricultural Economy: Experience of Other Countries", [Online], available at: ttp://www.ukraine.fibl.org/fileadmin/documents-ukraine/ (Accessed 2 April 2019).

6. Chychkalo-Kondratska, I. and Novitska, I. (2018), "Global Experience in Promotion of Organic Products", Effective economy, [Online], vol. 2, available at: http://www.economy.nayka.com.ua/pdf/2_2018/10.pdf (Accessed 11 April 2019).

7. FiBL \& IFOAM (2016), "The World of Organic Agriculture: statistics and Emerging Trends, Frick and Boon", [Online], available at: http://orgprints.org/31151/1/willer-lernoud2016-world-of-organic.pdf (Accessed 2 April 2019).

8. Wiswall, R. (2009), "The Organic Farmer's Business Handbook: A Complete Guide to Managing Finances, Crops, and Staff - and Making a Profit", Chelsea, Green Publishing, Boon, Germany.

9. Official website of the Ministry of Agrarian Policy and Food Ukraine (2017), [Online], available at: http://minagro.gov.ua/ - (Accessed 12 April 2019).

10. Official site of The Global Food Security Index (2018), "Global Food Security Index model", [Online], available at: https://foodsecurityindex.eiu.com/Resources (Accessed 15 March 2019).

11. Lebid, L. (2012), "Legalized Rules for Organics", Agrarian week [Online], available at: https://a7d.com.ua/agropoltika/agri-work/8579uzakonen-pravila-dlya-organki.html (Accessed 4 April 2019).

12. Hryniv, L. S. (2016), Fizychna ekonomiia: novi modeli staloho rozvytku [Physical economies: new models of consistent development], Ligapress, Lviv, Ukraine.

Стаття надійшла до редакиіӥ 06.05.2019 p. 
УАK 657.411:658.15

\author{
А. В. Коваль, \\ к. е. н., Аоцент кафедри бухгалтерського обліку, \\ Вінницький національний аграрний університет, м. Вінниця \\ ORCID ID: 0000-0003-3637-850x \\ В. В. Болехівська, \\ студентка магістратури факультету обліку та аудиту, \\ Вінницький національний аграрний університет, м. Вінниця \\ ORCID ID: 0000-0002-3906-8008
}

DOI: $10.32702 / 2306-6792.2019 .9 .53$

\title{
БУХГАЛТЕРСЬКИЙ ОБАІК ВААСНОГО КАПІТААУ В УПРАВАІННІ ПІАПРИСМСТВОМ
}

\author{
L. Koval, \\ Ph.D. in Economics, Associate Professor of the Accounting \\ Department, Vinnytsia National Agrarian University, Vinnytsia \\ V. Bolekhivska, \\ Masters degree of the Accounting Department, Vinnytsia National Agrarian \\ University, Vinnytsia
}

\section{ACCOUNTING OF OWN CAPITAL IN MANAGEMENT ENTERPRISE}

У статті представлено інформацію стосовно бухгалтерського обліку власного капіталу, а саме в управдінні підприємством. Оскільки на сьогоднішній день власність є фундаментом сучасної підприємницької діяльності, в дослідженні розглянуто сутність даного поняття, з різних наукових точок зору. Розглянуто основні складові власного капіталу, конкретизовано його основні функції. Приділили увагу дослідженню важливості управління, так як воно передбачає ефективне використання та отримання максимальних прибутків в процесі його діяльності, виділили етапи Аій управлінського персоналу в процесі прийняття управлінських рішень, що в свою чергу допоможе в прийнятті правильного рішення, яке призведе Ао високих показників діяльності, також виокремили основні напрями управління власним капіталом підприємства та яке програмне забезпечення використовується в бухгалтерському обліку.

The article presents information on the accounting of equity, namely in the management of the enterprise. So, as today's property is the foundation of modern entrepreneurial activity, the study examines the essence of this concept, from different scientific points of view. The main components of equity capital are considered, its main functions are specified. They focused on the study of the importance of management, since it involves the effective use and maximization of profits in the process of its activities, identified the stages of the actions of management staff in the process of making managerial decisions, which in turn will help in making the right decision, which will lead to high performance, as well outlined the main areas of management of the company's own capital and the software used in accounting.

At the present stage of development of the domestic market economy, the role and importance of accounting, which is responsible for providing information management of the enterprise, promotes efficient use of all its available resources, ensures the completeness and reliability of displaying data on the financial and property status of the entity.

The most significant indicator that characterizes the financial position of an enterprise is equity. Therefore, the issues of its formation, use and management are important in the management of both private and public enterprises, and it can also be added that equity is the basis of sustainable growth and financial sustainability.

Information about equity is the basis for analytical forecasts for the future development of the enterprise. Thus, the important task of any enterprise is the growth of own capital. Of course, in today's conditions, an increase in equity can not be achieved without the development and implementation of effective managerial decisions. In the process of managing own capital, it is necessary to have constant control over its change, which in turn will allow us to identify the reasons for its change. In this aspect, there is a need for a comprehensive analysis of equity capital, the definition of factors for its change and the development of management directions.

Equity is the financial basis of an enterprise, and the very existence of capital is a condition for business creation and development. An enterprise that carries out business activities, separated from others, must own capital. The very structure and dynamics of equity is the most significant indicator that determines the financial position of the enterprise. Equity represents part of the property of an enterprise, which is funded by the owners and owners' own funds. That is, it is not only a foundation for the establishment of an enterprise, but also stability and continuation of its economic activity. 
One of the most significant indicators that characterizes the financial position of the company is equity. Therefore, the question of controlling its formation, use are important in the management of the activities of any business entity. Information about equity should be the basis for analytical forecasts for the future development of the enterprise. In this regard, the requirements for the content and quality of the reporting information on equity capital are increasing significantly.

Ключові слова: власний капітал, фінансова стійкість, облік, управління, інформачіл.

Key words: equity, financial stability, accounting, management, information.

\section{ПОСТАНОВКА ПРОБЛЕМИ}

На сучасному етапі розвитку вітчизняної ринкової економіки все більше посилюється роль і значення бухгалтерському обліку, що відповідає за інформаційне забезпечення менеджменту підприємства, сприяє ефективному використанню всіх його наявних ресурсів, забезпечує повноту та достовірність відображення даних про фінансово-майновий стан суб'єкта господарювання.

Найсуттєвішим показником, що характеризує фінансовий стан підприємства, є власний капітал. Тому питання його формування, використання та управління мають важливе значення в управлінні діяльності як приватних, так і державних підприємств, також можна додати, що власний капітал $є$ основою стійкого росту та фінансової стійкості.

Інформація про власний капітал $€$ підгрунтям для аналітичних прогнозів щодо майбутнього розвитку підприємства. Таким чином, вагомим завданням будь-якого підприємства $є$ ріст власного капіталу. Звичайно, що в сучасних умовах збільшення власного капіталу неможливе без розробки та реалізації ефективних управлінських рішень. У процесі управління власним капіталом необхідним $€$ постійний контроль за його зміною, що в свою чергу дозволить виявляти причини його зміни. У цьому аспекті виникає необхідність комплексного аналізу власного капіталу, визначення факторів його зміни та розробки напрямів управління.

\section{АНАЛІЗ ОСТАННІХ ДОСЛІДЖЕНЬ І ПУБЛІКАЦІЙ}

Облік власного капіталу досліджений в науковій літературі як вітчизняними, так і зарубіжними вченими-економістами: В.Ю. Фабіянська, та О.П. Петровська, В.В. Сопко,

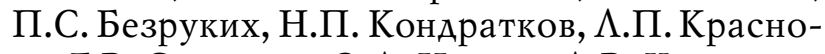
ва, Г.В. Савицька, О.А. Нужна, А.В. Хмелевська та Г.М. Незборецька та багато інших.

\section{META CTATTI}

Основною метою статті є висвітлення ролі обліку власного капіталу в управлінні підприємством.

Таблиця 1. Поняття власний капітал з точки зору науковців

\begin{tabular}{|l|l|l|}
\hline $\begin{array}{c}\text { № } \\
\text { п/п }\end{array}$ & \multicolumn{1}{|c|}{ Автори } & \multicolumn{1}{|c|}{ Визначення власного капіталу } \\
\hline 1 & \multicolumn{1}{|c|}{2} & \multicolumn{1}{|c|}{3} \\
\hline 1 & $\begin{array}{l}\text { П.С. Безруких, } \\
\text { Н.П. Кондратков, } \\
\text { Л.П. Краснова, } \\
\text { Г.В. Савицька }\end{array}$ & $\begin{array}{l}\text { Як джерело утворення майна, } \\
\text { основне джерело фінансування [3, } \\
\text { с. 372] }\end{array}$ \\
\hline 2 & В В. Сопко & $\begin{array}{l}\text { Це сума власних коштів } \\
\text { підприємства, яка утворена } \\
\text { внаслідок позитивних результатів } \\
\text { діяльності, внесків учасників або } \\
\text { залишена на підприємстві } \\
\text { безоплатно [4, с. 48] }\end{array}$ \\
\hline 3 & О.І. Пилипенко & $\begin{array}{l}\text { Загальнавартість власних засобів } \\
\text { підпри- ємства, які належать йому } \\
\text { на правах власності і } \\
\text { використовуються ним для } \\
\text { формування його активів [5, с. 8] }\end{array}$ \\
\hline 4 & О.А. Нужна & $\begin{array}{l}\text { Сума власних засобів } \\
\text { підприємства, які належать йому на } \\
\text { правах власності і } \\
\text { використовуються для придбання } \\
\text { активів [6, с. 500] }\end{array}$ \\
\hline 5 & $\begin{array}{l}\text { А.В. Хмелевська та } \\
\text { Г.М. Незборецька }\end{array}$ & $\begin{array}{l}\text { Цедифікована величина } \\
\text { заборгованості підпиємства його } \\
\text { засновникам у розмірі вартості } \\
\text { активів, які ним забезпечуються [7, } \\
\text { с. 193] }\end{array}$ \\
\hline & &
\end{tabular}


Таблиця 2. Складові власного капіталу підприємства

\begin{tabular}{|l|l|}
\hline $\begin{array}{l}\text { 3ареєстрований } \\
\text { капітал }\end{array}$ & $\begin{array}{l}\text { Юридично оформлена та офіційно об'явлена частина внесків } \\
\text { власників до капіталу підприємства. У тому числі виділяють: } \\
\text { статутний капітал та пайовий }\end{array}$ \\
\hline \multicolumn{1}{|c|}{$\begin{array}{l}\text { Капітал у } \\
\text { дооцінках }\end{array}$} & $\begin{array}{l}\text { Сума дооцінки необоротних активів і фінансових } \\
\text { інструментів }\end{array}$ \\
\hline $\begin{array}{l}\text { Додатковий } \\
\text { капітал }\end{array}$ & $\begin{array}{l}\text { Відображається емісійний дохід, вартість безкоштовно } \\
\text { отриманих необоротних активів, сума капіталу, який } \\
\text { вкладено засновниками понад статутний капітал, накопичені } \\
\text { курсові різниці, які відповідно до національних положень } \\
\text { (стандартів) бухгалтерського обліку відображаються у складі } \\
\text { власного капіталу та інші складові додаткового капіталу }\end{array}$ \\
\hline $\begin{array}{l}\text { Резервний } \\
\text { капітал }\end{array}$ & $\begin{array}{l}\text { Наводиться сума резервів, створених відповідно до чинного } \\
\text { законодавства або установчих документів за рахунок чистого } \\
\text { прибутку підприємства }\end{array}$ \\
\hline $\begin{array}{l}\text { Нерозподілений } \\
\text { прибуток } \\
\text { (непокритий } \\
\text { збиток) }\end{array}$ & $\begin{array}{l}\text { Відображається накопичена сума чистого прибутку, що } \\
\text { залишається на підприємстві після розподілу або чистого } \\
\text { збитку, в результаті отримання негативного фінансового } \\
\text { результату за звітний період }\end{array}$ \\
\hline $\begin{array}{l}\text { Вилучений } \\
\text { капітал }\end{array}$ & $\begin{array}{l}\text { Господарські товариства відображають фактичну собівартість } \\
\text { акцій власної емісії або часток, викуплених товариством у } \\
\text { иого учасників. Сума вилученого капіталу наводиться в } \\
\text { дужках і підлягає вирахуванню при визначенні підсумку } \\
\text { власного капіталу }\end{array}$ \\
\hline $\begin{array}{l}\text { Неоплачений } \\
\text { капітал }\end{array}$ & $\begin{array}{l}\text { Відображається сума заборгованості власників (учасників) за } \\
\text { внесками до статутного капіталу. Ця сума наводиться в } \\
\text { дужках і вираховується при визначенні підсумку власного } \\
\text { капіталу }\end{array}$ \\
\hline
\end{tabular}

Ажерело: [9-10].

\section{ОСНОВНІ РЕЗУЛЬТАТИ ДОСЛІДЖЕННЯ}

Власний капітал $€$ фінансовою основою підприємства, саме наявність капіталу є умовою створення та розвитку бізнесу. Підприємство, що здійснює підприємницьку діяльність, відокремлену від інших, повинно володіти капіталом. Сама структура та динаміка власного капіталу є найсуттєвішім показ- ником, що визначає фінансовий стан підприємства. Власний капітал показує частину майна підприємства, яка фінансується за рахунок коштів власників і власних засобів підприємства. Тобто він $є$ не тільки фундаментом для створення підприємства, а й стабільністю і продовженням його господарської діяльності [1, c. 309].

\begin{tabular}{|c|c|}
\hline Функці & ного капіталу \\
\hline $\begin{array}{l}\text { Заснування та введення в дію } \\
\text { підприсмства }\end{array}$ & $\begin{array}{l}\text { Власний капітал у частині статутного } \\
\text { є фінансовою основою для запуску в } \\
\text { дію нового суб'єкта господарювання }\end{array}$ \\
\hline Відповідальності та гарантії & $\begin{array}{l}\text { Статутний капітал є свого роду } \\
\text { кредитним забезпеченням для } \\
\text { кредиторів підприємства }\end{array}$ \\
\hline Захисна & $\begin{array}{l}\text { Чим більший власний капітал, тим } \\
\text { краще захищеним } є \text { підприємство від } \\
\text { впливу загрозливих для його } \\
\text { iснування факторів }\end{array}$ \\
\hline Стабілізацї̈ & $\begin{array}{l}\text { Власний капітал виступає основним } \\
\text { індикатором фінансової стійкості } \\
\text { підприємства }\end{array}$ \\
\hline Розподілу & $\begin{array}{l}\text { Обсяг власного капіталу визначає } \\
\text { пропорцію розподілу чистого } \\
\text { прибутку між власниками } \\
\text { підприємства }\end{array}$ \\
\hline Забезпечення ефективності & $\begin{array}{l}\text { Наявність власного капіталу в } \\
\text { джерелах формування майна } \\
\text { забезпечує ефективність діяльності } \\
\text { підприємства }\end{array}$ \\
\hline
\end{tabular}

Рис. 1. Функції власного капіталу 
Таблиця 3. Напрями управління власним капіталом підприємства

\begin{tabular}{|l|l|l|}
\hline \multicolumn{3}{|c|}{ Напрями управлінн власним капіталом підприємства } \\
\hline На етапі формування: & На етапі використання: & $\begin{array}{l}\text { На етапі розподілу } \\
\text { чистого прибутку: }\end{array}$ \\
\hline $\begin{array}{l}\text { Забезпечення своєчасного } \\
\text { внесення коштів до статутного }\end{array}$ & $\begin{array}{l}\text { Забезпечення власного } \\
\text { капіталу в обороті }\end{array}$ & $\begin{array}{l}\text { Розробка дивідендної } \\
\text { політики }\end{array}$ \\
\hline $\begin{array}{l}\text { Забезпечення відрахувань із } \\
\text { прибутку до резервного } \\
\text { капіталу }\end{array}$ & $\begin{array}{l}\text { Вкладення власних } \\
\text { коштів у прибуткові } \\
\text { інестиційні проекти }\end{array}$ & $\begin{array}{l}\text { Визначення } \\
\text { капіталізованої та } \\
\text { споживчої частки } \\
\text { чистого прибутку }\end{array}$ \\
\hline $\begin{array}{l}\text { Збільшення нерозподіленого } \\
\text { прибутку }\end{array}$ & $\begin{array}{l}\text { Визначення потреби в } \\
\text { інвестиціях та оцінка } \\
\text { альтернативних джерел }\end{array}$ \\
\hline
\end{tabular}

Одним із найсуттєвіших показників, що характеризує фінансовий стан підприємства, є власний капітал. Тому питання контролю за його формуванням, використанням мають важливе значення в управлінні діяльності будь-якого господарюючого суб'єкта. Інформація про власний капітал повинна бути основою для аналітичних прогнозів щодо майбутнього розвитку підприємства. У зв'язку з цим вимоги до змісту та якості звітної інформації про власний капітал істотно зростають [2].

Взагалі власний капітал як об'єкт обліку почав розглядатись 3 моменту розвалу $\mathrm{Pa-}$ Аянського союзу та створення в Україні ринкової економіки і налаштування системи бухгалтерського обліку, відповідно до світових стандартів. Перш ніж розглянути особливості бухгалтерського обліку власного капіталу в управлінні підприємством, визначимо сутність цього економічного терміну. Проаналізувавши Ажерела наукової літератури можна зробити висновок, що існують різні бачення даного поняття (табл. 1), які більш детально описані в таблиці.

Тобто з вищенаведених тверджень, щодо сутності власного капіталу, ми розуміємо, що чітко одного визначення не існує, думки у науковців досить різні, наприклад Т. С. Яровенко та К.П. Свистільник звертають увагу на те що власний капітал доцільно визначати як основу створення й розвитку господарської діяльності підприємства, а також головну складову його загального потенціалу у вигляді початково зареєстрованих та додатково створених власних коштів (засобів) [8, с. 190].

На сьогоднішній день керуючись національним положенням (стандартом) бухгалтерського обліку 1 "Загальні вимоги до фінансової звітності", яке затверджено Міністерством фінансів України 07.02.2013 р. № 73, зазначається, що власний капітал - це частина в активах підприємства, що залишається після вирахування його зобов'язань [9].

Розмір власного капіталу підприємства відображається у першому розділі пасиву ба- лансу, а джерела його створення у звіті про власний капітал. Згідно з Методичними рекомендаціями, власний капітал включає в себе зареєстрований, додатковий, резервний, неоплачений та вилучений капітал, капітал у дооцінках, нерозподілений прибуток (непокритий збиток) [10]. Більш детальний опис про кожну складову власного капіталу, наведено в таблиці (табл. 2).

У цілому власний капітал відіграє досить важливу роль в діяльності підприємства, що проявляється у його функціях (рис. 1).

Реалізація вищенаведених функцій дає змогу досягнути досить високӧ̈ ефективності фінансово-господарської діяльності підприємства.

Ми вважаємо, що не менш важливою складовою на будь-якому, підприємстві не залежно від форми власності, є необхідність здійснювати управлінську діяльність. Ефективна діяльність суб'єктів господарювання України потребує управління фінансовими ресурсами. Інвестори надають перевагу тим підприємствам, де функціонує ефективне управління власним капіталом, що в свою чергу забезпечить захист інтересів та покаже ефект від використання вкладених ними коштів.

Управління забезпечує планування, організацію, мотивацію, контроль та регулювання діяльності. Аосягнення будь-якої мети можливе тільки за допомогою плідної праці колективу підприємства. Необхідно правильно організувати діяльність персоналу, враховуючи їх інтереси та застосовувати певні заохочення та стимулювати свій персонал для ефективної та плідної праці на благо підприємства. Будь-який контроль забезпечує порівняння досягнутих результатів із запланованими.

Ядром управлінських рішень та самої діяльності виступає облікова інформація. Адже від правильно сформованої бухгалтерської інформації буде залежати подальше функціонування підприємства та його здатність конкурувати. Тобто облікова інформація є основною, i сутність їі полягає в можливості керівництва 
здійснювати попередній, поточний і подальший контроль.

При здійсненні тих, чи інших маніпуляцій 3 власним капіталом підприємства важливим етапом є формування управлінського рішення щодо розподілу та використання. При наявності альтернативних проектів управлінських рішень їх вибір для реалізації повинен базуватися на системі критеріїв, які визначають політику управління прибутком підприємств.

Виділяють етапи дій управлінського персоналу в процесі прийняття управлінських рішень:

1. Аіагноз, тобто визнання проблеми. Виявляється та описується проблемна ситуація на основі якої буде проводитись оцінка альтернативних варіантів вирішення проблеми.

2. Накопичення інформації про проблему. Виконується збір та обробка інформації різного характеру щодо проблеми, яка розглядається.

3. Розробка альтернативних варіантів вирішення проблеми. Описується та складається перелік всіх можливих варіантів дій, що забезпечують вирішення проблемної ситуації.

4. Оцінка альтернативних варіантів. 3дійснюється перевірка ідентифікованої альтернативи за критеріями: реальність, відповідність ресурсам які має в своєму розпорядженні підприємство, прийнятність наслідків реалізації альтернативи.

5. Прийняття рішень. Вибір кращої альтернативи яка вирішить цю проблему в найкоротші строки.

Незалежно від того, яке підприємство та якою діяльністю займається, важливою ланкою $€$ налагоджена система управління. Отже, необхідна взаємодія між управлінським персоналом та виконавцями щодо досягнення поставлених цілей фінансово-господарської діяльності підприємства. Вищенаведені етапи є основою в роботі системи управління, оскільки вони реалізують ефективне функціонування підприємства.

Наведемо основні напрями управління власним капіталом підприємства (табл. 3).

Ефективне управління власним капіталом призведе до збільшення його обсягу. У процесі управління власним капіталом необхідно враховувати як внутрішні так і зовнішні фактори та чітко виокремлювати загрози та можливості. Основними факторами внутрішнього середовища є: вид діяльності та його специфіка, обсяги майна підприємства, наявність інноваційних технологій. Щодо зовнішніх факторів впливу виділяють наступні: податкове законодавство, економічну ситуацію в країні, конкурентоспро- можність, темп інфляції, валютну політику держави.

Хотілося б звернути увагу на програмне забезпечення, а саме програми бухгалтерського обліку. Більшість підприємств застосовують професійні програми бухгалтерського обліку, як-от: "1С:Бухгалтерія", "ПАРУС", "Галактика", SAP тощо, які спеціалізовані на замовлення конкретного суб'єкта господарювання, задля автоматизації конкретних завдань обліку. Але це призводить до чималих витрат. Як негативний приклад можна зазначити програмне забезпечення бюджетних установ. Програмні пакети, які використовуються державними установами є досить неактуальними на сьогоднішній день, що, як наслідок, призводять до негативних результатів роботи підприємств. Звичайно покращило б ситуацію застосування більш сучасних програм.

\section{ВИСНОВОК}

Підсумовуючи все вищезазначене, можна стверджувати, що ефективне управління власним капіталом є основним критерієм прибуткової діяльності та фінансової стабільності. Оскільки на сьогоднішній день власність є ядром сучасної підприємницької діяльності, що передбачає їі ефективне використання та отримання максимальних прибутків у подальшому. Також ми розглянули різні підходи до сутності визначення власного капіталу та узагальнили дане питання. Визначили та систематизували основні напрями управління власним капіталом підприємства.

\section{\ітература:}

1. Сук А.К. Фінансовий облік: [навч. посіб.] А.К. Сук, П.А. Сук. - К.: Знання, 2012. - 647 с.

2. Фабіянська В.Ю. Основні підходи до проведення аудиту власного капіталу підприємства Фабіянська В.Ю., Петровська О.П. Проблеми економічного, облікового, контрольного і аналітичного забезпечення управління підприємством: матеріали I Всеукр. наук.-практ. конф. молод. науковців, 14-15 квітня 2016 року. Вінниця, ВНАУ, 2016. - С. 147-151.

3. Вівчар О.Й. Власний капітал як фінансове Ажерело функціонування підприємства О.Й. Вівчар, В.М. Саварин Науковий вісник НАТУ України. - 2009. - Вип. 19.5 - С. 146150 .

4. Сопко В.В. Власний капітал акціонерних товариств: особливості визначення та обліку В.В. Сопко // Науковий вісник Національного лісотехнічного університету України: збірник науково-технічних праць. - 2007. - Вип. 17.6. - C. $246-253$. 
5. Пилипенко О.І. Облік та аналіз власного капіталу: теорія і практика: автореф. дис. на здобуття наук. ступеня канд. екон. наук 08.06.04 Бухгалтерський облік, аналіз та аудит О.І. Пилипенко. - К., 2005. - 20 с.

6. Нужна О.А. Власний капітал сільськогосподарських підприємств: трактування, класифікація, структура О.А. Нужна Збірник наукових праць Ауцького національного технічного університету: наук. журнал. Економічні науки. Серія облік і фінанси. - 2012. - Вип. 9 (33). Ч. 2. - C. $498-507$.

7. Хмелевська А.В. Власний капітал за атрибутами об'єкту бухгалтерського обліку А.В. Хмелевська, Г.М. Незборецька Сталий розвиток економіки. - Хмельницький: Університет економіки і підприємництва. - 2011. - № 4. C. $192-194$.

8. Яровенко Т.С. Удосконалення методології бухгалтерського обліку власного капіталу в сучасних умовах Т.С. Яровенко, К.П. Свистільник // Вісник Аніпропетровського університету - Вип. 7 (2). - 2013. - С. 189-194. (Сер.: Економіка).

9. Національне положення (стандарт) бухгалтерського обліку 1 "Загальні вимоги до фінансової звітності" затверджене наказом Міністерства фінансів України від 07.02.2013 р. № 73 [Електронний ресурс]. - Режим доступу: http://www.me.gov.ua

10. Методичні рекомендації щодо заповнення форм фінансової звітності затверджені наказом Міністерства фінансів України від 23.03.2013 р. № 433 (зі змінами та доповненнями) [Електронний ресурс]. - Режим доступу: http://www.me.gov.ua

\section{References:}

1. Suk, L.K. and Suk, P.L. (2012), Finansovyj oblik, [Teach manual], Znannja.

2. Fabijansjka V.Ju. and Petrovsjka, O.P. (2016), "The main approaches to the audit of the enterprise's own capital",: Materialy I Vseukr. nauk.-prakt. konf. molod. naukovciv [Materials I Allukr. sci. pract. conf. young scientists], Problemy ekonomichnogho, oblikovogho, kontroljnogho i analitychnogho zabezpechennja upravlinnja pidpryjemstvom [Problems of economic, accounting, control and analytical support of enterprise management], VNAU, Vinnytsia, Ukraine.

3. Vivchar, O. J. and Savaryn, V. M. (2009), "Equity as a financial source for the functioning of the enterprise", Naukovyj visnyk, vol. 19.5, pp. $146-150$.

4. Sopko, V.V. (2007), "Equity capital of jointstock companies: features of definition and accounting", Naukovyj visnyk Nacionaljnogho lisotekhnichnogho universytetu Ukrajiny: zbirnyk naukovo-tekhnichnykh pracj, vol. 17.6, pp. 246-253.

5. Pylypenko, O. I. (2005), "Accounting and analysis of equity", Ph.D. Thesis, Accounting, analysis and audit, Ukraine.

6. Nuzhna, O.A. (2012), "Own capital of agricultural enterprises: interpretation, classification, structure", Nauk. zhurnal. Ekonomichni nauky. vol. 9 (33) - Ch. 2., pp. 498-507.

7. Khmelevsjka, A. V. and Nezborecjka Gh. M. (2011), "Equity according to the attributes of the object of accounting", Stalyj rozvytok ekonomiky, vol. № 4, pp. 192-194.

8. Jarovenko, T. S. and Svystiljnyk, K. P. (2013), "Improvement of the accounting methodology of equity capital in modern conditions", Visnyk Dnipropetrovsjkogho universytetu, vol. 7(2), pp. 189-194.

9. Ministry of Finance of Ukraine (2013), "General requirements for financial statements", available at: http://www.me.gov.ua.( Accessed 07 february 2013).

10. Ministry of Finance of Ukraine (2013), "Methodical recommendations for filling out forms of financial reporting", available at: http:// www.me.gov.ua.( Accessed 23 march 2013).

Стаття надійшла до редакиї̈ 26.04.2019 р.

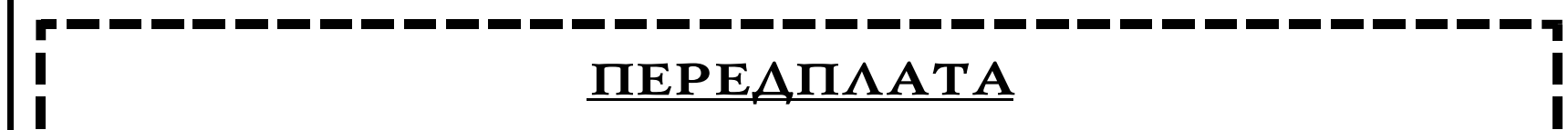

ВИААННЯ МОЖНА ПЕРЕАПААТИТИ З БУАЬ-ЯКОГО МІСЯЦЯ! - ЧЕРЕЗ РЕААКЦІЮ (ТЕА. 458-10-73);

- ЧЕРЕЗ АП "ПРЕСА" (У КАТААОЗІ ВИААНЬ УКРАЇНИ); - ЧЕРЕЗ ПЕРЕАП $А$ АТНI АГЕНТСТВА 